UNIVERSIDADE DE SÃO PAULO

DEPARTAMENTO DE CIÊNCIA POLÍTICA

SERGIO SIMONI JÚNIOR

\title{
FLUTUAÇÃO ELEITORAL E SISTEMA PARTIDÁRIO: O CASO DE SÃO PAULO
}

VERSÃO CORRIGIDA

São Paulo

2012 
SERGIO SIMONI JÚNIOR

\section{FLUTUAÇÃO ELEITORAL E SISTEMA PARTIDÁRIO: O CASO DE SÃO PAULO}

DisSERTAÇÃo APRESEnTAdA À FACULdAde de Filosofia, Ciências e Letras da Universidade de São Paulo para a OBTENÇÃo do TÍtUlo DE MESTRE EM Ciência Política.

Orientador: Prof. Dr. Fernando LIMONGI.

São Paulo

2012 
Nome: SIMONI JR., Sergio.

Título: Flutuação eleitoral e sistema partidário: o caso de São Paulo.

Aprovado em:

DisSERTAÇÃo APRESENTAda À FACULDAde

de Filosofia, Ciências e Letras da

Universidade de São Paulo para a

OBTENÇÃo DO TÍtUlo DE MESTRE EM Ciência Política.

Orientador: Prof. Dr. Fernando LIMONGI.

Banca examinadora

Prof. Dr.:

Instituição:

Julgamento:

Assinatura:

Prof. Dr.:

Julgamento:

Prof. Dr.:

Julgamento:

Instituição:

Assinatura:

Instituição:

Assinatura: 
SIMONI JR., S. Flutuação do voto e sistema partidário: o caso de São Paulo. 2012. 136

p. Dissertação de mestrado - Faculdade de Filosofia, Letras e Ciências Humanas, Universidade de São Paulo, São Paulo.

\section{RESUMO}

O tema deste estudo é o papel dos partidos políticos brasileiros no momento eleitoral sob o prisma da volatilidade eleitoral. A questão da volatilidade é um dos principais tópicos de análise na área eleitoral e, em especial, sobre sistema partidário e sua evolução. Diz respeito à estabilidade/mudança, no tempo, da direção partidária do voto por parte do eleitor. No Brasil, o debate se trava em torno da institucionalização do sistema partidário e da relação deste com o eleitorado. Argumenta-se, de modo geral, que os partidos brasileiros manteriam relação fluída com os eleitores, o que configuraria um quadro de competição eleitoral instável e volúvel. Os paradigmas teóricos mobilizados pela abordagem tradicional são inspirados na sociologia política e eleitoral, e apontam, em geral, a falta de correspondência sólida entre partidos e clivagens sociais.

Busco apresentar nesta dissertação uma versão alternativa. A fundamentação do argumento se dá, do ponto de vista teórico, por meio da reconstrução do caminho percorrido pela noção de volatilidade eleitoral, tal como ele se desenvolve na academia européia, conjugada com um diálogo com outro conjunto de literatura, encontrado marcadamente na academia americana, de inspiração institucionalista e na escola da escolha racional, interessado na competição eleitoral. Esse embasamento possibilitará uma visão teórica e analítica diversa da literatura nacional sobre o fenômeno da volatilidade no Brasil. Do ponto de vista empírico, proponho uma mudança de foco em relação aos estudos tradicionais: enquanto esses analisam os pleitos legislativos, defendo que estudos centrados nos cargos executivos possibilitam uma visão mais acurada sobre volatilidade e sistema partidário, pois essas são as disputas mais importantes para os partidos e para os eleitores.

O objeto empírico deste estudo são os resultados eleitorais para o estado de São Paulo, nas eleições para cargos do Executivo, ou seja, presidente, governador, e prefeito da capital, nos anos de 1982 a 2008, com foco no período pós-94. A hipótese da pesquisa é que a volatilidade eleitoral, mensurada pelo índice de Pedersen, tradicional na literatura, é causada, em grande medida, por estratégias dos partidos políticos, ao 
decidirem pelo lançamento e retirada de candidaturas, não se devendo, necessariamente, a debilidades do sistema partidário ou ao comportamento e preferências instáveis do eleitor. Obviamente, existem mudanças de preferências, mas procuro mostrar que em São Paulo os partidos apresentaram bases eleitorais definidas.

Palavras-chave: volatilidade eleitoral, sistema partidário, comportamento eleitoral, São Paulo. 
SIMONI JR., S. Flutuação do voto e sistema partidário: o caso de São Paulo. 2012. 136 p. Dissertação de mestrado - Faculdade de Filosofia, Letras e Ciências Humanas, Universidade de São Paulo, São Paulo.

\begin{abstract}
The central theme of this work is the role of Brazilian political parties and electoral volatility at the time of election. Volatility is one of the major topics of analysis concerning electoral studies and the evolution of party systems. It addresses the stability and change, during certain period of time, of the elector's vote for any given party. In Brazil, the debate deals with the institutionalization of the party system and its relationship with the electorate. It is generally argued that Brazilian parties maintain a fluid relationship with voters, which configures an unstable and fickle electoral competition framework. The theoretical paradigms used by the main approach are inspired by electoral and political sociology, and they tend to indicate, in general, the lack of strong correspondence between parties and social cleavages.
\end{abstract}

In this dissertation, I offer an alternative approach. Theoretically, the ground of my argument is given by reconstructing the discussion of electoral volatility, as it has developed in the European academy, combined with a dialogue with another set of literature, found notably in the American academy, inspired by institutionalist and rational choice school, interested in electoral competition. This foundation will enable a theoretical and analytical vision different from the traditional literature about electoral volatility in Brazil. I propose an empirical change of focus, from the analysis of legislative elections, as it was common in brazilian studies, to an executive-centered analysis. I argue that executive-centered studies enable a more accurate view of volatility and party system, since executive disputes are more importante both for parties and voters.

The empirical object of this work are the election results of the state of São Paulo, in Executive elections, President, Governor and Mayor of capital, from 1982 to 2008, focusing on the post-94 period. My hypothesis is that electoral volatility, as measured by the Pedersen index, is largely caused by political parties' strategies and decisions of who should and who should not be its candidates. Thus electoral volatility should not necessarily be caused by the weaknesses of brazilian party system or 
unstable behavior and preferences of voters. Obviously, there are changes in preferences, but I try to show that in São Paulo, parties had well defined constituencies.

Keywords: electoral volatility, party system, electoral behavior, São Paulo. 
Dedico este trabalho à minha família, pelo amor indescritível 


\section{Agradecimentos}

Essa dissertação é fruto de um longo e intenso processo de convivência e aprendizagem, com muitas pessoas, situações e instituições. As poucas linhas que se seguem não são suficientes para expressar o que merece ser dito neste momento.

Agradeço primeiramente à minha querida família, meu pai Sergio, minha mãe Edina, meu irmão Marcelo e minha avó Elisabeth, pelo carinho cotidiano, pelas alegrias e diversões constantes e pelo apoio incomensurável.

Esta dissertação teve início, e deve muito, aos trabalhos desenvolvidos no CEMCEBRAP (Centro de Estudos da Metrópole - Centro Brasileiro de Análise e Planejamento), e aos participantes dos grupos de estudos dos profs. Fernando Limongi e Paolo Ricci. Sou enormemente grato às oportunidades que tive nessas instituições e grupos de pesquisa. Registro, especialmente, as pessoas que estiveram ao longo dos anos mais envolvidas com minhas pesquisas: à Andreza e Lara agradeço a ajuda e parceria em diversos momentos, ao Patrick pelas nossas pesquisas conjuntas, e ao Tiago Borges e Thiago Nascimento agradeço fortemente a amizade, o companheirismo e os comentários em versões anteriores do texto.

O curso de graduação em Ciências Sociais e o mestrado em Ciência Política na USP trouxeram-me experiências acadêmicas sem igual. Muitos professores foram essenciais na minha formação. Cito especialmente os professores Adrian Lavalle, André Singer, Eduardo Marques e Marta Arretche, que me marcaram pela seriedade e dedicação na atividade docente.

Agradeço aos comentários dos professores que participaram de minha banca de qualificação e da apresentação do seminário discente do Departamento de Ciência Política da USP: professora Maria do Socorro Souza Braga e professor Paolo Ricci. Fiquei honrado de tê-los debatendo meu trabalho.

Quero registrar que o prof. Paolo Ricci foi um amigo e apoiador em diversas ocasiões.

Aos amigos do CIS (Consórcio de Informações Sociais), Davi à testa, agradeço as agradáveis experiências recentes. 
Aos funcionários do departamento de Ciência Política, especialmente Rai e Vasne, agradeço a ajuda em muitos momentos.

Muitos amigos e companheiros da Faculdade de Filosofia, Letras e Ciências Humanas e do programa de pós-graduação em Ciência Política fizeram pare de minha trajetória. Das pessoas que estiveram mais envolvidas no meu percurso ao longo desses anos, agradeço à Jaqueline e Samantha pelo apoio e ajuda, Camila e Ricardo pelas conversas e leituras de versões anteriores, Osmany e Rafael pela companhia e alegrias em diversos momentos, e a San, por tudo.

Por fim, agradeço ao meu orientador, prof. Fernando Limongi. Sua dedicação e primado pela excelência são motivo de inspiração para todos.

Esse trabalho foi financiado pela Capes e pela Fapesp.

Soli Deo Gloria 
SUMÁRIO

ÍNDICE DE TABELAS 10

ÍNDICE DE GRÁFICOS 12

ÍNDICE DE QUADROS 12

INTRODUÇÃO 13

CAPÍTULO I - Literatura sobre Volatilidade Eleitoral 15

O debate europeu 15

Institucionalização Política 26

América Latina e Brasil 31

Síntese 40

CAPÍTULO II - Ligação Partido-Eleitor 41

Sociologia Eleitoral___ 41

A escolha de Michigan e a Psico-sociologia___ 45

A escola racional e o comportamento Eleitoral__ 48

O debate americano sobre competição eleitoral__ 52

Síntese_ 58

CAPÍTULO III - Pressupostos teóricos e metodológicos adotados__ 60

Democracia e Competição Eleitoral___ 60

Índice de volatilidade de Pedersen__ 63

A unidade de análise___ 67

Hipótese e Interpretação__ 70

Ideologia e comportamento Eleitoral___ 73

Estrutura dos dados__ 75

Caso Escolhido__ 79

CAPÍTULO IV - Eleições e volatilidade em São Paulo___ 81

Eleições Presidenciais 1989-2006___ 81

Eleições para Governador 1982 - 2006___ 93

Presidente e Governador por município___ 103

Comparação Presidente Governador__ 105

Eleições para prefeito 1985-2008__ 106

Síntese Geral___ 114

CONSIDERAÇÕES FINAIS___ 116

Bibliografia___ 119

Anexos _ 127 


\section{Lista de tabelas}

Tabela 1 - Número de Seções consideradas

Tabela 2 - Distribuição da Educação por seção 78

Tabela 3 -Volatilidade eleitoral Pedersen - Presidente - Nível do Estado de São Paulo $\%$

Tabela 4 - Volatilidade eleitoral - Presidente - Nível das seções eleitorais- \% 83

Tabela 5 - Volatilidade eleitoral - Presidente - Nível dos municípios - \%

Tabela 6 - Cenário Contrafactual -Volatilidade eleitoral - Presidente - Nível do Estado de São Paulo - \%

Tabela 7 -Volatilidade eleitoral - Presidente - Quartis educacionais - \% 87

Tabela 8 - Regressão Linear Simples - Volatilidade Eleitoral Pedersen / Educação Presidente

Tabela 9 - Cenário Contrafactual - Volatilidade eleitoral - Presidente - Quartis

educacionais - \% 88

Tabela 10 - Regressão Linear simples - Cenário Contrafactual / Educação -

Presidente 88

Tabela 11 - Regressão linear simples - PT / Educação - Presidente 90

Tabela 12 - Regressão linear simples - PDSB / Educação - Presidente 91

Tabela 13 - Volatilidade Eleitoral Pedersen - Governador - Nível do Estado de São Paulo - \% 93

Tabela 14 - Volatilidade eleitoral - Governador - Nível das seções eleitorais - \%_94

Tabela 15 - Volatilidade eleitoral - Governador - Nível dos municípios - \% 94

Tabela 16 - Cenário Contrafactual - Volatilidade Eleitoral - Governador - Nível do Estado de São Paulo \% 95

Tabela 17 -Volatilidade eleitoral - Governador - Quartis educacionais \% 97

Tabela 18 - Regressão Linear simples - Volatilidade Eleitoral Pedersen / Educação Governador 97 
Tabela 19 - Cenário Contrafactual -Volatilidade eleitoral - Governador - Quartis educacionais \% 98

Tabela 20 - Regressão Linear simples - Cenário Contrafactual / Educação -

Governador 98

Tabela 21 - Regressão linear simples - PT / Educação - Governador 99

Tabela 22 - Regressão linear simples - PSDB / Educação - Governador 100

Tabela 23 - Regressão linear simples - PP / Educação - Governador 101

Tabela 24 -Volatilidade eleitoral - Presidente - Nível dos Municípios de São Paulo -

Quartis de tamanho - \% 103

Tabela 25 -Cenário Contrafactual - Volatilidade eleitoral - Presidente - Nível dos Municípios de São Paulo - Quartis de tamanho - \% 104

Tabela 26 -Volatilidade eleitoral - Governador - Nível dos Municípios de São Paulo Quartis de tamanho - \% 104

Tabela 27 -Cenário Contrafactual - Volatilidade eleitoral - Governador - Nível dos Municípios de São Paulo - Quartis de tamanho - \%

Tabela 28 - Volatilidade Eleitoral Pedersen - Prefeito - Nível da Cidade de São Paulo $\%$ 107

Tabela 29 - Volatilidade eleitoral - Prefeito - Nível das seções eleitorais - \% 107

Tabela 30 - Cenário Contrafactual - Volatilidade Eleitoral - Prefeito - Nível da Cidade de São Paulo \% 109

Tabela 31 - Volatilidade eleitoral - Prefeito - Quartis educacionais - \% 109

Tabela 32 - Regressão Linear simples - Volatildade Eleitoral Pedersen / Educação -

Prefeito 109

Tabela 33 - Cenário Contrafactual - Volatilidade Eleitoral - Prefeito - Quartis educacionais - $\%$ 110

Tabela 34 - Regressão Linear simples - Cenário Contrafactual / Educação Prefeito 110

Tabela 35 - Regressão linear simples - PT / Educação - Prefeito 111 
Tabela 36 -Regressão linear simples - PSDB / Educação - Prefeito 112

Tabela 37 -Regressão linear simples - PP / Educação - Prefeito 113

Tabela 38 - Volatilidade eleitoral em diversos países - \% 114

Tabela 39 - Volatilidade eleitoral década de 1990 - \% 115

\section{Índice de quadros}

Quadro 1 - Eleição em T1 64

Quadro 2 - Eleição em T2 64

Quadro 3 - Flutuação real do voto 64

Quadro 4 - Eleição em T1 71

Quadro 5 - Eleição em T2 71

Quadro 6 - Codificação de Escolaridade no Cadastro Eleitoral 77

Quadro 7 - Eleições Presidenciais - Candidaturas por Partidos Selecionados 84

Quadro 8 - Eleições para Governador de SP - Candidaturas por Partidos Selecionados 95

Quadro 9 - Eleições Prefeito de São Paulo - Partidos Participantes_ 108

\section{Índice de gráficos}

Gráfico 1 - PT Presidente 90

Gráfico 2 - PSDB Presidente 91

Gráfico 3 - PT Governador 99

Gráfico 4 - PSDB Governador 100

Gráfico 5 - PP Governador 101

Gráfico 6 - PT Prefeito 111

Gráfico 7 - PSDB Prefeito 112

Gráfico 8 - PP Prefeito 113 


\section{Introdução}

O debate sobre a institucionalização do sistema partidário é um dos mais prementes no âmbito da Ciência Política nacional. Diz respeito ao campo mais geral de pesquisas sobre o funcionamento da democracia no Brasil. O conceito de volatilidade eleitoral é um dos principais tópicos de análise sobre a relação entre os partidos, o sistema partidário e os eleitores, e sua evolução no tempo. Do ponto de vista teórico, a noção de volatilidade eleitoral se relaciona com a idéia de representação política, de identificação partidária, de competição eleitoral. Do ponto de vista empírico, versa sobre a estabilidade/mudança da direção partidária do voto por parte do eleitor.

Esta temática surge entre os analistas do cenário europeu nos anos 70, motivados em apreender o possível desalinhamento nas relações partido-eleitor em alguns contextos nacionais. No campo brasileiro, com a redemocratização dos anos 80, o conceito de volatilidade foi e é utilizado como um dos instrumentais analíticos para se compreender o processo e o grau de institucionalização dos partidos em específico, e do governo representativo de modo geral. Teriam os partidos brasileiros bases eleitorais mais ou menos estáveis? Os eleitores flutuam seu voto em grau elevado e de maneira errática?

Diferentemente da motivação inicial, na qual o índice de volatilidade era utilizado como uma das evidências em favor da tese da quebra dos laços políticos entre partidos e cidadãos na Europa, outrora estáveis, no Brasil a intenção era verificar se as novas legendas seriam capazes de criar identificação com grupos de eleitores e estabelecer um contexto organizado de competição democrática.

Dado o arcabouço das teorias da modernização e do desenvolvimento político, a expectativa analítica que se criou sobre o caso brasileiro ressaltava as dificuldades que os partidos e os eleitores teriam em configurar uma situação de baixa flutuação eleitoral. A debilidade organizacional, a ausência de uma cultura partidária, dentre outros fatores, contribuiriam, segundo esta perspectiva, para altos índices de volatilidade no Brasil.

Note-se que o conceito de volatilidade ou flutuação eleitoral carrega em si uma carga negativa e pejorativa. A analogia com o mundo da química, onde volatilidade é uma propriedade de uma substância que diz respeito à tendência ou facilidade da passagem do estado líquido para o gasoso, conota uma situação, no mundo político e 
social, de transformação de padrões estáveis de interação partido-eleitor para outro pautado pela inconstância e volubilidade. O eleitor que muda a direção partidária de seu voto é comparado, por analogia, ao enfraquecimento das interações entre as partículas de uma substância quando esta passa do estado líquido em direção ao gasoso.

Neste trabalho, busca-se uma visão alternativa. Para tanto, utilizo duas frentes de argumentação: uma teórica, por meio da mobilização de uma literatura que possibilite pensar o fenômeno da mudança de voto em outros patamares; outra empírica, com a proposta e apresentação de novos objetos e testes empíricos.

A construção teórica consiste na apresentação de um conjunto de estudos sobre a relação partido-eleitor que permite pensar a existência e o comportamento do eleitor inconstante sem um viés negativo ${ }^{1}$. Ademais, esse conjunto da literatura, inspirado pela teoria da escolha racional, coloca como variável-chave para o entendimento do momento eleitoral a estratégia partidária. Desse modo, pode-se pensar o fenômeno da volatilidade como condicionado por outros fatores que não os ressaltados pelas análises tradicionais, tanto as nacionais quanto internacionais.

Quero sublinhar que não é intenção desta dissertação discutir ou construir modelos formais de teoria dos jogos, como os textos acima referidos muitas vezes o fazem. O uso que faço desta literatura é antes substantivo que técnico: trata-se de trazer novos aportes para se pensar o fenômeno da volatilidade dentro da motivação do debate clássico no qual esse conceito surge, qual seja, a institucionalização do sistema partidário, os tipos de ligação partido-eleitor, etc.

De ponto de vista empírico, proponho que o principal objeto das análises para o caso brasileiro dever ser os cargos majoritários para o executivo, e não os pleitos legislativos, como é usual na literatura. Os primeiros são privilegiados por partidos e eleitores e, portanto, são mais adequados a uma discussão que visa debater a importância dos partidos na direção de voto do eleitor.

O presente trabalho consiste num estudo de caso dos resultados eleitorais para o estado de São Paulo, das eleições para cargos do Executivo, ou seja, presidente, governador e prefeito da capital, nos anos de 1982 a 2008, com foco no período pós-94.

\footnotetext{
${ }^{1}$ No âmbito do debate normativo, no capítulo III apresento uma breve discussão do significado da flutuação do voto para a competição democrática.
} 
A seção empírica é dedicada a diversos testes quantitativos para apreender em que medida pode-se falar que o eleitorado paulista é volúvel. A hipótese da pesquisa é que a volatilidade eleitoral, mensurada pelo índice de Pedersen, tradicional na literatura, é causada, em grande medida, por estratégias dos partidos políticos, ao decidirem pelo lançamento e retirada de candidaturas, não se devendo, necessariamente, à debilidades do sistema partidário ou ao comportamento e preferências instáveis do eleitor. Logicamente, existem mudanças de preferências, mas defendo que essas "respeitam" as bases sociais dos partidos: procurarei mostrar que as principais legendas apresentaram no período bases eleitorais identificáveis e constantes. A flutuação do voto, também, corresponde a um contexto de longo prazo da dinâmica do sistema partidário: primeiro a transição política nos anos 80, no qual o bipartidarismo forçado do período militar cedeu lugar ao multipartidarismo legal, e, depois, na década de 90, a construção da bipolaridade da disputa do executivo nacional, que influencia, em maior ou menor grau, as demais disputas.

O trabalho está dividido como segue: no capítulo $I$, faço brevemente a reconstrução da noção da volatilidade eleitoral, tal como surge no cenário acadêmico europeu dos anos 70, e de que forma ela é utilizada nos estudos comparados que envolvem o Brasil; no capítulo II busco apresentar algumas bases teóricas que fundamentam a discussão sobre o eleitor volátil, oriundas das teorias do comportamento eleitoral, e proponho uma visão alternativa à utilizada de modo geral pela literatura; no capítulo III apresento os procedimentos metodológicos adotados, bem como um ponto normativo; no capítulo IV encontra-se a análise empírica; as considerações finais vêem em seguida.

\section{Capítulo I - Literatura sobre Volatilidade Eleitoral}

\section{O debate europeu}

A temática da volatilidade eleitoral emerge e ganha força particularmente no cenário acadêmico europeu dos anos 70, ligando-se a questões que dizem respeito às relações entre partidos e classes sociais, tipo e natureza dos partidos, ideologia e representação. De modo geral, esse conceito empírico buscava relatar fenômenos de mudanças estruturais na esfera político-partidário dos países europeus, dialogando criticamente com um conjunto de argumentos prévios que balizavam parte da visão que 
se tinha sobre aqueles sistemas partidários. Antes de adentrarmos especificamente nas discussões teóricas e metodológicas do indicador de volatilidade eleitoral, passemos pela reconstituição do contexto no qual esses argumentos tomam força.

O ponto de partida do debate é a visão formulada por Lipset e Rokkan, no final dos anos 60. Pautados por uma perspectiva da sociologia política, os autores estabeleceram a famosa tese do "congelamento do sistema partidário europeu", tese esta que seria posta à prova e considerada datada por autores que utilizam o índice de volatilidade eleitoral.

Lipset e Rokkan realizam uma análise do conflito político europeu numa perspectiva macro-histórica, relacionando a emergência dos partidos e dos sistemas partidários a conflitos societais de grande porte. Os partidos exerceriam, então, nas instituições políticas papel de expressão das divisões que ocorrem na estrutura social.

Essas divisões são conceituadas como clivagens sociais: basicamente, são categorias essencialmente dicotômicas que expressam as divisões sociais resultantes de grandes transformações/revoluções. A primeira delas é a Revolução Nacional, quando da unificação do Estado-Nação. Esse processo de centralização do poder pode gerar dois pares de oposição: elite central/elite periférica e governo/Igreja. O segundo grande acontecimento histórico é a Revolução Industrial, que também pode levar a dois pólos conflitivos: elite urbana-industrial/elite agrária e capital/trabalho. Essas categorias reverberariam nos partidos políticos, configurando diferentes cenários políticos nacionais de acordo com os diversos caminhos históricos percorridos.

A intenção de Lipset e Rokkan é propor um modelo de análise comparada para compreender como os sistemas partidários europeus se identificam e se diferenciam, baseando-se em conflitos, alianças e processos históricos e sociológicos. A tese do "congelamento do sistema partidário" é fruto da constatação de que, a partir dos anos 20 do século passado, o quadro partidário dos diferentes países europeus assumira um formato que perduraria até o momento em que os autores escreviam (anos 60). Mais detidamente, os três primeiros conflitos mencionados anteriormente, basicamente intraelites, determinariam como se daria a incorporação política da classe trabalhadora 
organizada no começo do século XX, muitas vezes com reformas no sistema eleitoral ${ }^{2}$. Assim, poder-se-ia dizer que, segundo os autores, o cenário partidário europeu "encapsularia" os conflitos sociais fruto das diferentes clivagens de maneira estável, de tal modo que mesmo as duas Grandes Guerras, as crises econômicas e novas configurações da ordem mundial não mudaram o núcleo do quadro partidário.

A tese e a perspectiva proposta por Lipset e Rokkan entram na literatura como um paradigma sociológico da visão sobre partidos e sistemas partidários, e, no que mais nos interessa aqui, sua institucionalização. Olhando para os partidos e seu arranjo sistêmico, os autores expressam a visão sociológica sobre comportamento eleitoral, na qual a motivação e a direção do voto tem como causa o pertencimento dos eleitores a diferentes grupos e classes sociais, que encontrariam em determinados partidos suas expressões políticas ${ }^{3}$.

Quero assinalar que não se deve exagerar o argumento do determinismo sociológico na visão de Lipset e Rokkan. Em que pese o fato das instituições políticas, como sistema eleitoral e sistema de governo, ocuparem um lugar secundário na análise, e a ênfase recair mais fortemente nos aspectos de identificação política, não deve deixar de ser notado que, quando relacionam partidos com competição eleitoral, os autores chamam atenção para a importância das ações estratégicas das elites políticas, com vistas à obtenção de mandatos, na formatação do quadro partidário. Mais do que isso, os autores afirmam que "no party can hope to gain decisive influence on the affairs of a community without some willingness to cut across existing cleavages to establish common fronts with potential enemies and opponents" (Lipset e Rokkan, 1990: 93). Ou seja, mesmo adotando uma perspectiva de forte linkage entre o sistema partidário e os conflitos sociais, Lipset e Rokkan assinalam o fato de que as atividades dos partidos não se resumem a expressões automáticas de clivagens sociais, mas também consistem de estratégias eleitorais que podem cortar transversalmente as divisões sociais. Como também mostra Lybeck (1985: 106), o verbo utilizado pelos autores para mostrar a existência de vínculos entre os partidos e clivagens é refletir, o que "may indicate that they did not conceive of the relationship as monocausal".

\footnotetext{
${ }^{2}$ Muitos países, nesse período, adotaram a representação proporcional, como a Finlândia, Suécia, Holanda, entre outros.

3 Ver o capítulo II sobre comportamento eleitoral.
} 
As diversas configurações sistêmicas de partidos europeus são efeito, pode-se dizer, de causas de duas ordens: de um lado, um processo macro-histórico, de formação de clivagens sociais, que define identidades grupais e configura conflitos; de outro, as estratégias eleitorais dos partidos, as alianças e os conflitos intra-elites políticas. Lipset e Rokkan certamente focam no primeiro argumento, mas não abrem mão de apontar a importância do segundo.

Em suma, ao estabelecer a tese do "congelamento" do sistema partidário europeu, e ao relacioná-lo ao acoplamento entre as clivagens sociais e os partidos políticos, Lipset e Rokkan estabelecem um marco analítico e teórico na temática dos partidos políticos e na sua relação com o eleitorado.

Rose e Urwin, em um artigo publicado originalmente em 1970, formulam indicadores para averiguar a tese proposta por Lipset e Rokkan, por eles chamada de "hipótese nula" (1990: 186), contra a qual se levantariam visões alternativas que esperariam encontrar instabilidade eleitoral ${ }^{4}$. De acordo com Rose e Urwin, são basicamente dois arcabouços que sustentam essa última expectativa: o primeiro, fruto de uma visão "evolucionária" dos partidos políticos, ou de tendências históricas, segundo o qual determinados tipos de partidos são apropriados para determinadas épocas, mudando estas, aqueles também devem se alterar ${ }^{5}$; a outra visão é pautada na teoria econômica da democracia ${ }^{6}$, que afirma que os partidos convergiriam para o eleitor mediano e "not only do voters shift their preferences but also that parties themselves change through time in a cybernetic process of adjustment" (Rose e Urwin, 1990: 186).

Isto posto, os autores discutem diversos índices que poderiam captar mudança ou permanência da força eleitoral dos partidos europeus. Esse impulso representa um das iniciativas pioneiras no sentido de estabelecer parâmetros empíricos para o teste de teorias sobre a relação partido-eleitor ao longo do tempo. Os autores utilizam medidas de tendências e medidas de flutuação da força partidária. A primeira indica se, no longo prazo, um partido cresce, descresce ou se mantém estável: isso pode assinalar as

\footnotetext{
${ }^{4}$ Aqui se pode verificar que já está explícita a conexão feita entre a tese de Lipset e Rokkan e a exigência de estabilidade eleitoral.

${ }^{5}$ Uma referência pertinente, mas não citada pelos autores, é Kirchheimer, cuja tese discutiremos abaixo.

${ }^{6}$ A referência feita pelos autores é Downs (1999).
} 
possíveis mudanças nos tipos de partidos predominantes nos sistemas partidários. A segunda se refere a mudanças de curto prazo, seja em relação à média do período, à tendência encontrada, ou a um mínimo ou máximo atingido no recorte histórico estabelecido.

A conclusão dos autores é corroborar Lipset e Rokkan:

"whatever index of change is used (...) the picture is the same: the electoral strength of most parties in Western nations since the war had changed very little from election to election, from decade to decade, or within the lifespan of a generation" (Rose e Urwin, 1990: 193).

Paralelamente a esse debate específico sobre volatilidade, a literatura sobre tipologias de partidos políticos é importante para a compreensão das questões envolvidas. Também no final dos anos 60, Kirchheimer formula um novo tipo de partido: o cath-all.

Sua tese é a de que após a II Guerra Mundial um conjunto de mudanças sociais e políticas na Europa dificultaram o sucesso eleitoral e político dos antigos modelos de partidos burgueses de representação e de partidos de massas respaldados em fortes divisões sociais. Os primeiros, partidos burgueses, também chamados por Duverger (1987) de partidos de quadros, foram os primeiros agrupamentos partidários surgidos no século XIX intra-parlamento, e se assentavam, essencialmente, numa sociedade de direitos políticos limitados. Os segundos, os de massa, são a expressão mais forte da institucionalização política do movimento dos trabalhadores e socialistas, e constituem o tipo de partido mais correlacionado com o paradigma levantado por Lipset e Rokkan.

Kirchheimer argumenta, entretanto, que as linhas que separavam os estratos sociais se empalidecem no pós-Guerra, dificultando estratégias políticas que apelavam para classes sociais específicas. Dentre as possíveis causas desse fenômeno, têm-se a necessidade dos partidos de assumirem posições de comando e governo, e não apenas de expressão de segmentos sociais, o que os levaria ao pragmatismo; a ampliação das políticas sociais de welfare-state, aplainando as lutas de classe, e um crescente processo de perda de centralidade da ideologia nas disputas políticas. Dessa forma, os partidos 
passariam a assumir um comportamento catch-all como recurso para elevar sua competitividade ${ }^{7}$.

Cabe notar que as interpretações de Lipset e Rokkan e Kirchheimer levam a uma interessante contradição: ambas sobrepõem períodos históricos, mas uma afirma que existe "congelamento" do sistema partidário com as clivagens, já a outra ressalta que as divisões societárias não mais constituem demarcações para a competição política ${ }^{8}$.

É dentro desse quadro que surge a questão da volatilidade eleitoral. A partir de final dos 70, alguns analistas entendem que o quadro traçado por Lipset e Rokkan não é capaz de dar conta da dinâmica partidária européia, fruto, em parte, do surgimento de partidos de perfil catch-all e das mudanças nas estruturas sociais e culturais. O ponto principal da discussão empírica diz respeito à instabilidade eleitoral: o argumento de Lipset e Rokkan levaria a pressupor que a flutuação de voto, a mudança da direção do voto entre um partido e outro feita pelo eleitor no tempo, seria pequena, visto a conexão forte entre partidos e clivagens.

Pedersen, num artigo publicado em 1979, é tido como o primeiro autor a estabelecer o índice de volatilidade eleitoral que seria utilizado pela literatura comparada para o teste da hipótese de "congelamento" do sistema partidário ou, nos termos de outro arcabouço teórico, para verificação de seu grau de "institucionalização" 9. O autor levanta indícios que aludem a uma instabilidade política na Europa, como o aumento do número de partidos, o surgimento de outros novos, a queda na identificação partidária, etc. Logo, procura formular algum indicador que possibilite uma base empírica robusta para o estudo da mudança do sistema partidário europeu.

Inicialmente, Pedersen (1990: 197) afirma que um estudo sobre essa temática deveria cobrir uma série de níveis, como os partidos no parlamento e no governo,

\footnotetext{
${ }^{7}$ Kirchheimer (1990: 53) não deixa de assinalar que, a despeito desse processo de não simetria entre conflitos sociais/ideologia e partidos, esses não são livres para assumir qualquer posição política, antes dependem de limites estabelecidos pela história de cada sociedade, como as disputas religiosas em alguns casos.

${ }^{8}$ Wolinetz (1990) defende que o declínio de alinhamentos partidários não levaria ao surgimento de partidos catch-all, antes ao aumento da fragmentação partidária e de pequenos partidos.

${ }^{9}$ Adiante discutiremos os pressupostos e implicações desse termo.
} 
partidos como organização e em relação ao eleitorado. Sua análise cobre apenas esse último nível, perfazendo um estudo sobre o formato do sistema partidário, ou seja, focado no número e na força dos partidos que competem em eleições ${ }^{10}$. Assim, inspirado em outros estudos ${ }^{11}$, o autor formaliza o índice que se tornará clássico na literatura $^{12}$.

A análise cross-section, com 13 países europeus, e time-series, de 1948 a 77, do índice de volatilidade mostra uma média crescente na flutuação eleitoral por década, não sem dinâmicas diferenciadas entre os países. Assim, o autor conclui que

"at the end of the 1970s the first priority is to understand why some party systems still appear to be stable while other systems either have been undergoing a transformation or have gone through a period of considerable instability" (Pedersen, 1990: 207).

É interessante notar que a volatilidade média do começo do período analisado, final dos 40 e começo dos 50, é de 7,8\%, não distando muito da volatilidade média do final do período, nos anos 70, de 9,2\%. Se a hipótese de Pedersen era de que a tese do "congelamento" de Lipset e Rokkan não era aplicável aos tempos recentes, seria de se esperar maior distância entre os índices.

De qualquer forma, a partir de Pedersen erigiu-se um conjunto de literatura destinado a afirmar o declínio da força dos partidos europeus, uma disjunção entre o eleitorado e o sistema partidário e, logo, a perda de centralidade das clivagens sociais.

Quero chamar atenção para um aspecto da abordagem de Pedersen que considero relevante para a proposta do presente trabalho. Como também notou Peres (2005: 94), Pedersen "propôs-se a analisar a relação entre uma variável estática (formato do sistema) e uma variável dinâmica (variação agregada nas votações dos partidos)". A primeira é constituída pelo número de partidos do sistema: calcado no modelo de Sartori (1982) ${ }^{13}$, Pedersen afirma que a variação da quantidade de partidos

\footnotetext{
${ }^{10}$ Esse ponto é importante para pensar o caso brasileiro: em que medida é possível fazer inferências sobre a mudança ou estabilidade do sistema partidário focando apenas na volatilidade eleitoral? Ou apenas nos partidos no Congresso?

${ }^{11}$ Entre eles, Rose e Urwin acima discutidos, e Przeworski (1975) que discutiremos abaixo.

${ }^{12}$ A fórmula matemática do índice de Pedersen se encontra no capítulo III.

${ }^{13}$ Uma citação que o autor poderia utilizar, de Sartori (1982: 381), é uma crítica que este faz a Downs: "Downs pode ter razão ao afirmar que qualquer distribuição de eleitores em qualquer estrutura eleitoral
} 
afeta a dinâmica do sistema, podendo alterar, portanto, o formato do mesmo. Peres sumariza (Idem): “o número de partidos em competição afetaria a dinâmica das votações, e como tal, a dinâmica sistêmica". Uma das hipóteses que examinarei é que a variação na apresentação de candidaturas ajuda a entender a volatilidade eleitoral para cargos executivos no Brasil.

Uma das principais discussões que se seguiram na literatura diz respeito à validade do teste das teses de Lipset e Rokkan: seria a medida de volatilidade eleitoral, tal como proposta por Pedersen, útil para tal?

Aqui temos uma das principais contribuições para o debate sobre volatilidade. Trata-se do livro de Bartolini e Mair, Identity, competition and electoral availability, publicado em 1990. O objetivo principal dos autores é questionar a tese de que, a partir da segunda metade do século $\mathrm{XX}$ as clivagens na Europa perderam proeminência e que, conseqüentemente, a volatilidade eleitoral teria crescido. Antes de falar mais detidamente deste ponto, gostaria de chamar atenção para alguns aspectos conceituais e teóricos do livro que acredito serem úteis e interessantes para a presente pesquisa. Consistem numa série de diferenciações estabelecidas pelos autores para o debate com a literatura teórica e empírica: a questão do curto e do longo prazo; da instabilidade eleitoral e política; e da volatilidade como propriedade sistêmica e individual.

Inicialmente, os autores chamam atenção para as duas diferentes perspectivas sobre a dinâmica eleitoral: de um lado, dentro do debate sobre "encapsulamento" do conflito político e, seu inverso, a volatilidade eleitoral, é ressaltada a estabilidade eleitoral; de outro, nas discussões sobre a legitimidade da democracia e a competição política $^{14}$, é assinalada como necessário para a ordem democrática a mudança, ou, a instabilidade eleitoral. Os autores argumentam que essas duas perspectivas não são contraditórias entre si, apenas enfatizam diferentes abordagens temporais: a primeira exige um olhar de longo prazo, chamando atenção para o fato de que a ordem

permite um determinado número de partidos e apenas esse número. O problema é que esse argumento se aproxima da circularidade, pois a distribuição resulta, em grande parte, do número de partidos sendo, portanto, condicionada pelos próprios".

${ }^{14}$ Pode-se fazer referência aqui à definição de democracia de Przeworski (1984), segundo a qual esta se caracteriza pela incerteza institucionalizada. 
democrática exige certo padrão de estabilidade do jogo eleitoral, a segunda enfatiza o curto prazo e a incerteza necessária ao jogo partidário-eleitoral.

Ademais, os autores também diferenciam instabilidade eleitoral de instabilidade política. Segundo eles, a literatura não problematiza a ligação imediata feita entre os dois fenômenos. Seu argumento é de que apenas certos tipos de instabilidade eleitoral (não apenas o grau de sua intensidade) importam para a instabilidade democrática.

No que se refere à terceira diferenciação, Bartolini e Mair argumentam que a flutuação eleitoral pode ser vista tanto como conseqüência de propriedades sistêmicas como de mudanças no comportamento individual. Na primeira visão, as estratégias das lideranças dos partidos, tanto no momento eleitoral, quanto no governo ou na oposição, conformam os níveis de volatilidade. Na segunda, a ênfase é colocada nas mudanças das preferências dos eleitores.

Acredito que esses pontos são importantes para se pensar o caso brasileiro. Algumas perguntas que podem ser formuladas: o que esperar do nosso recente sistema partidário no curto e no longo prazo? A volatilidade eleitoral é indicativa de nãoconsolidação democrática? Em que medida ela é fruto das ações estratégicas dos partidos?

Voltando a Bartolini e Mair, estes autores endereçam, então, a questão das clivagens tais como teorizadas por Lipset e Rokkan e o argumento posterior de sua inadequação para se pensar a relação partido-eleitor na Europa pós anos 60. Os autores defendem que o índice de volatilidade eleitoral, tal como formulado por Pedersen e utilizado, grosso modo, por quase toda literatura, não é adequado para testar a hipótese de Lipset e Rokkan. A crítica está na suposição de que mudanças nas votações dos partidos equivalem à mudança no peso das clivagens. Os autores argumentam que o texto de Lipset e Rokkan em nenhum momento afirma que o sistema de clivagens se traduz em partidos individuais competindo um com o outro:

"putting these points together suggests an important distinction between the individual party organisation, on the one hand, and the organised expression of the cleavage, on the other, with the latter capable of incorporating more than one party" (Bartolini $\mathrm{e}$ Mair, 1990: 64). 
Assim, a unidade empírica do índice de volatilidade eleitoral deveria ser, segundo Bartolini e Mair, partidos agrupados em blocos, blocos esses consistindo em clivagens importantes para a competição eleitoral. No caso em análise, eleições européias numa série temporal que cobre 100 anos (1885 a 1985), os autores escolheram a clivagem classista para agrupar os partidos. Do ponto de vista da fórmula matemática, isso pouco muda: agora blocos que congregam mais de um partido (ou podem congregar) constituem a variável de análise, de tal modo que só ocorrerá volatilidade na medida em que eleitores mudarem de voto para partidos pertencentes a diferentes blocos. Em outras palavras, Bartolini e Mair apresentam o índice de volatilidade ideológica, tal como ficou conhecido pela literatura posteriormente, ou volatilidade inter-blocos.

As conclusões dos autores são que o "espectro da instabilidade", a visão segundo a qual a volatilidade e o desalinhamento eleitoral seriam crescentes na Europa, não se verifica empiricamente. Antes, Bartolini e Mair afirmam que existe um forte "viés em direção à estabilidade" na dinâmica eleitoral européia ${ }^{15}$.

Mair (1997), em outro texto, abarca a questão da volatilidade no registro de uma discussão sobre "mudança do sistema partidário". O autor afirma que a tese da volatilidade eleitoral pressupõe um impacto na configuração do sistema partidário. Isso aconteceria, de acordo com a teoria, de duas maneiras. Na forma direta, o argumento corre na direção de estabelecer uma ligação imediata entre flutuação eleitoral e mudanças no sistema de partidos; na sua forma indireta, a teoria defende que a mudança eleitoral impacta no sistema de clivagens, e então as transformações nesse nível causam efeito no sistema partidário. Mair foca na crítica a essas duas perspectivas. No que diz respeito à forma indireta, além da crítica acima endereçada sobre a equivalência entre partidos individuais e clivagens, o autor relembra também que os determinantes sociais do comportamento político, as clivagens, não têm um impacto direto e sem mediações com o sistema político-partidário ${ }^{16}$. Assim, alterações nas clivagens podem acontecer sem que ocorra mudança de sistema partidário, afinal esse possui propriedades

\footnotetext{
${ }^{15}$ Cabe assinalar que, ao restringir o número de unidades de análise, o índice de volatilidade eleitoral necessariamente diminui.

${ }^{16}$ Stoll (2004) argumenta de forma semelhante, mostrando que existem várias camadas de clivagens sociais e políticas no que diz respeito ao seu efeito na competição eleitoral.
} 
sistêmicas próprias. Em relação à primeira visão, Mair afirma haver um excessivo viés eleitoral nos estudos sobre mudança de sistema partidário, o que acaba sobrevalorizando o resultado das eleições na formatação do mesmo, e também leva à desconsideração de outras variáveis importantes, como aspectos ideológicos e organizacionais. Assim, é plausível imaginar que se pode ter uma situação com baixa volatilidade eleitoral, mas cujos partidos adotaram forte comportamento adaptativo, mudando suas plataformas e sua organização interna ${ }^{17}$.

Para finalizar esse debate, cabe chamar atenção para outro aspecto da obra de Mair, agora em co-autoria com Katz, sobre tipologias de partidos políticos. Nos anos 90, os autores defenderam a tese da existência de um novo tipo de partido político, diferente do de quadros, de massas ou do catch-all. Os autores o cunharam de "partido cartel", numa referência ao fenômeno econômico de articulação entre empresas concorrentes para benefício mútuo (Katz e Mair, 1995; 2009). A tese de Katz e Mair é a de que as condições sociais e culturais do final do século XX, como o desenvolvimento da tecnologia da informação, a globalização e o surgimento de entidades supranacionais, a diminuição no antagonismo de classes e o declínio das grandes ideologias mudaram radicalmente o perfil e o papel dos partidos políticos. Esses, na atualidade, se caracterizariam por um comportamento de "conluio", garantindo benefícios próprios oriundos do Estado, mitigando o caráter de conflito e procurando elevar as barreiras de entrada. Ao contrário de muitos que propugnam o declínio e falta de importância dos partidos na atualidade, os autores afirmam que esses mantêm prerrogativas ao se voltarem para a sua relação com o Estado. A questão do financiamento e dos recursos públicos, da capacidade de nomeações na burocracia, etc., permite aos partidos permanecerem como entidades importantes nos sistemas políticos contemporâneos ${ }^{18}$. Neste quadro, a competição eleitoral não levaria a uma situação de claros ganhadores e perdedores, seria antes mitigada pela concessão de benefícios mútuos entre os maiores partidos, sejam da situação ou oposição.

$\mathrm{Na}$ literatura nacional, Kinzo (2004) afirma que o afastamento da sociedade civil promovido pelo partido cartel não ocorre sem problemas para a representação política.

\footnotetext{
${ }^{17}$ Conforme Mair (1997, 72-3), esse foi o caso irlandês.

18 No debate brasileiro, Meneguello (1996) é uma das primeiras autoras a chamar atenção para a pertinência dessa vertente teórica para se pensar o processo de institucionalização dos partidos brasileiros.
} 
Neste trabalho, acredito que a dimensão da relação partido-eleitor é importante para a avaliação sobre o funcionamento do governo representativo, mas considero relevante o argumento da centralidade do Estado na conformação do sistema partidário. Minha tese é que os partidos brasileiros mantêm bases eleitorais mais ou menos estáveis, e que essas são influenciadas, mas não totalmente determinadas, pela posição que os partidos mantêm com o Executivo.

\section{Institucionalização Política}

$\mathrm{O}$ conjunto de literatura ligada à temática sobre institucionalização e desenvolvimento político abarcou, em seu arcabouço teórico e empírico, discussões que tocavam, ainda que muitas vezes implicitamente, a volatilidade ou instabilidade eleitoral. As visões advindas desse marco teórico influenciaram os primeiros estudos comparados voltados para a "terceira onda" de democratização, e logo, para o Brasil. A intenção nesta seção é registrar alguns fios cognitivos visando a compreensão de como o debate sobre volatilidade eleitoral emerge na discussão nacional e/ou voltada para o caso brasileiro durante e logo após o período da transição, e problematizar sua utilidade heurística para o contexto atual.

A principal referência da literatura de desenvolvimento político para a discussão sobre volatilidade é Huntington (1975), na sua clássica discussão comparada sobre ordem e estabilidade política e os processos de modernização. Segundo o autor, "a institucionalização é o processo através do qual as organizações e os processos adquirem valor e estabilidade" (1975: 24). Do ponto de vista do sistema político, institucionalizados são aqueles que desenvolvem e atualizam suas estruturas analogamente à modernização sócio-econômica, de modo que seja a eles possível responder às pressões e demandas sociais. A tensão subjacente é a de que as etapas iniciais da modernização e o desenvolvimento econômico e social quebrariam os laços primários de pertencimento e identidade dos indivíduos, sem que estes sejam substituídos imediatamente por outros, causando, no âmbito político, comportamentos imprevisíveis, desordenados e radicalizados.

O ponto central, portanto, está no grau e na rapidez em que ocorreriam os fenômenos da mobilização política, entendida esta como a incorporação das massas ao sistema político. O paradigma do desenvolvimento político argumenta que incrementos rápidos e massivos de inclusão e participação política levam a erosão dos padrões de 
interação política, ou seja, a processos de enfraquecimento das instituições. Numa perspectiva histórica e comparada, as teses de Huntington levantam cautela para os processos de redemocratização e de ampliação dos direitos políticos: as instituições presentes podem não suportar as demandas e preferências dos ingressantes ${ }^{19}$. O problema é a um só tempo sociológico e institucional. Sociológico porque diz respeito a processos de socialização e de padronização de interações sociais. Institucional porque se volta sobre as estruturas e procedimentos das relações de poder.

Focando a discussão para o âmbito do comportamento eleitoral, a visão do desenvolvimento político deduz que as massas ingressantes no processo de escolha de dirigentes políticos teriam preferências instáveis, tendentes à radicalização, quebrando a estabilidade eleitoral de outrora. Isso porque essa mudança eleitoral é fruto tanto da inadequação entre o sistema social em transformação quanto da estrutura política. Aqui, e a passagem é importante, eleitor volátil é igualado a eleitor com tendência à radicalização.

Przeworski foi um autor que, focando nas discussões sobre estabilidade/instabilidade eleitoral, empreende um embate teórico contra as teses do desenvolvimento político, notadamente as formulações de Huntington. Para tal, chega a conceber, em 1975, uma fórmula matemática semelhante a que Pedersen desenvolveria mais tarde, no índice de volatilidade. Mais especificamente, Przeworski busca construir um modelo formal e empírico que relacione os movimentos de mobilização (participação eleitoral) com a (de)institucionalização política. A hipótese nula, por assim dizer, é a de que o comportamento estável dos eleitores antigos, fruto da socialização e institucionalização prévia, seria abalado pela entrada de novos contingentes de cidadãos que não tinham passado pelos processos de "padronização".

Przeworski procura então formalizar os argumentos implícitos e explícitos nessas teses e aplicá-los empiricamente para dez países desenvolvidos, numa série temporal que remonta ao final do século XIX. Os testes empíricos realizados não confirmam as teses do desenvolvimento político: às ondas de mobilização não se

\footnotetext{
${ }^{19}$ Dahl (1997), ao estabelecer os dois eixos que balizam a poliarquia, a participação e oposição, também alerta para os perigos de se expandir fortemente o primeiro, sem aumentar o grau de oposição. Mas podese depreender do argumento de Huntington de que a mobilização política, causadora dos processos de decadência institucional, diz respeito a ambos os processos, ampliação tanto da participação quanto da oposição, não se confundindo, portanto, com o argumento de Dahl.
} 
seguiram fraqueza das instituições (deinstitutionalization) (ou, pode-se dizer, volatilidade eleitoral).

Para além das ponderações sobre o alcance de seus testes empíricos, o que Przeworski ressalta é a ênfase excessiva que é colocada, pela literatura, no poder dos indivíduos sobre as instituições, ou sobre as elites, em certas teorias de participação política. A visão de que o surgimento de novos eleitores e a mudança das preferências dos antigos ameaçam a ordem político-institucional leva, segundo o autor, a uma subvalorização do papel das instituições no regulamento dos conflitos sociais. Ao contrário, o que Przeworski sugere é que o incremento da mobilização e da participação política são trazidas à tona apenas quando as instituições vigentes já estão ameaçadas. $\mathrm{O}$ aumento da participação e da oposição seria, portanto, resultado de ações estratégicas das elites políticas ${ }^{20}$. No que diz respeito à estabilidade/instabilidade das preferências eleitorais, o autor levanta um ponto que gostaria de chamar atenção. Na esteira da relação entre elites políticas e eleitores, Przeworski (1975: 65-6) discute qual a principal origem da flutuação eleitoral:

"Changes of voting distribution did not occur because new individuals entered the electorate, nor because old voters "decided" to shift their preferences, but because the manner in which they could vote and the conditions under which they did vote were altered independently of their will. (...). Distribution of votes reflect strategies of party leaderships, strengths of political ideologies (...). Voters have little to decide; what they decide and how they decide is determined by conditions give to each independently of his choosing".

O autor chama atenção aqui para a importância do comportamento das elites político-partidárias nas escolhas dos eleitores. A volatilidade destes pode ser vista então como resultado não de mudanças de preferências, mas antes como alteração nos quadros de escolhas possíveis. Partidos decidem se lançam ou não candidato, se se coligam ou não, moldando os quadros de decisão dos cidadãos políticos. Esta constitui a minha hipótese principal para o estudo da volatilidade eleitoral para cargos majoritários no Brasil.

Segundo Limongi (2000, 2002), o paradigma do desenvolvimento político balizou em grande medida a literatura nacional voltada para as discussões sobre

\footnotetext{
20 Obviamente Przeworski não deixa de notar a importância de fatores exógenos aos fenômenos estudados, como a Guerra.
} 
partidos, eleitores e democratização. Os estudos eleitorais realizados nos anos 70, especialmente o coordenado por Reis em 1978, balizados ainda pela perspectiva psicológica do comportamento eleitoral ${ }^{21}$, teriam como objetivo, dentre outros, averiguar em que medida o eleitor médio nacional seria compatível com os requisitos exigidos pela democracia representativa. A utilização do arcabouço de Converse, de sistema de crenças, teria por meta, segundo Limongi, verificar até que ponto a votação e a adesão ao MDB, partido de oposição ao regime militar, consistiam em identificação fundada em opiniões políticas coerentes ou estavam antes balizadas por imagens difusas.

Reis, em diversos textos sobre comportamento eleitoral, cunhou a expressão "Síndrome do Flamengo", que designaria a expressão política dos setores mais desfavorecidos da sociedade brasileiro. Utilizando-se da tipologia de Pizzorno (1966), que integra, num modelo de participação política, as dimensões de centralidade e de consciência de classe, Reis afirma que grande parcela do eleitorado brasileiro não seria capaz de expressar seus interesses de classe devido à posição social marginal ocupada, configurando uma situação de "marginalidade subjetiva". A força eleitoral e identitária do MDB teria por base uma imagem difusa e simplificada, na qual o mundo político seria dividido entre "pobres" e "ricos". A adesão ao partido oposicionista se assemelharia ao torcer por um time de futebol. A questão posta num momento de ampliação do quadro partidária e de abertura democrática é: como se comportaria o eleitor popular tendo em vista a quebra do cenário simplificado no qual ele atuava nos anos $70 ?$

Com o início da redemocratização, a Ciência Política brasileira, em consonância com a virada teórica realizada pela literatura sobre transições políticas, incorporou, em grande medida, a perspectiva analítica do neo-institucionalismo. Assim, o sucesso da consolidação democrática dependeria não mais de fatores estruturais, culturais ou de longo prazo, mas, agora, das instituições políticas a serem adotadas. Mais especificamente, a visão predominante focou em duas instituições: o sistema de governo e as leis eleitorais ${ }^{22}$.

\footnotetext{
${ }^{21}$ Ver capítulo II sobre comportamento eleitoral.

${ }^{22}$ Para um texto clássico sobre presidencialismo e parlamentarismo, ver Linz (1991)
} 
No que diz respeito ao sistema partidário e eleitoral, de acordo com Limongi (2002), a principal referência da literatura brasileira foi Sartori (1968). Nesse texto, fruto de uma conferência do autor no Brasil em 1966, Sartori combina as visões do desenvolvimento político com as da engenharia institucional. Apoiando-se em Huntington, afirma que "political development is polity building, the creation of differentiated political structures, functions and capabilities" (Sartori, 1968: 263). O constitucionalismo, entretanto, que seria o instrumento clássico de engenharia política, não é suficiente para modelar uma sociedade política baseada nas massas.

"That is to say that the pace and the paths of mass behavior are set - within but also beyond the constitutional frame - by the parties and the party system. The "channeling agencies" par excellence are the parties: channelment is primarily a party business" (Idem: 273).

Os partidos políticos deveriam receber maior atenção nos processos de desenvolvimento político e construção institucional por sua função de intermediação entre a sociedade (as massas) e o Estado. E o principal mecanismo de manipulação, nas palavras do autor, é a definição do sistema eleitoral. Aqui, o autor retoma Duverger, reformula suas "leis", e defende o papel de freio, por assim dizer, realizado pelo sistema eleitoral: principalmente nos momentos de redemocratização, com expectativas elevadas e extensão dos direitos políticos, a massa da população, caracterizadas por Sartori (1968: 277) como "illiterate and deprived", deve ter seu comportamento político canalizado e fortemente delimitado por um sistema eleitoral e partidário "forte".

Este adjetivo indica, aqui, a capacidade dessas instituições em influenciar as preferências e o comportamento dos eleitores. Os sistemas eleitorais fortes seriam os de tendência majoritária, em detrimento dos proporcionais. Quanto aos sistemas partidários, os efetivos são constituídos pelos partidos de massa, que são capazes de estruturação nacional e se relacionam com os indivíduos por meio de imagens abstratas.

Temos, assim, um notável hibridismo teórico entre visões sobre desenvolvimento político e "terapias institucionais". A utilização, explícita ou implícita, de tal visão no Brasil ainda é corroborada pela tradição de nosso pensamento social e político em assinalar os dilemas de nossa história política fruto das incompatibilidades entre nossa estrutura social e cultural e as instituições políticas formais. Um dos mais conspícuos autores no campo da análise política é Vitor Nunes Leal (1975). 
O caso brasileiro, e de outras nações latino americanas, seria especialmente complicado, pois a adoção da representação proporcional não teria sido precedida pela devida estruturação do quadro partidário. Assim, teríamos a situação de que tanto o sistema eleitoral quanto o partidário seriam "fracos", tendendo a uma situação de pluralismo polarizado.

Segundo Limongi (2002), a referência à necessidade de fortalecimento dos partidos, na Ciência Política brasileira, traz, direta ou indiretamente, o pano de fundo das teorias da modernização e do desenvolvimento político. Os estudos sobre volatilidade eleitoral, no início da transição, estavam preocupados com a adequação entre a massa dos eleitores e o multipartidarismo e as eleições diretas para cargos executivos.

\section{América Latina e Brasil}

O debate sobre volatilidade, no que diz respeito à América Latina, e também ao Leste Europeu, emerge numa preocupação inversa quando de sua gênese no cenário do oeste europeu: trata-se agora de verificar a possibilidade da consolidação democrática, que, segundo a literatura, exigia a institucionalização do sistema partidário, e, portanto, padrões estáveis de relacionamento entre eleitor e partido no tempo. Ou seja, podemos dizer que a expectativa da literatura comparada com a democracia na América Latina, na sua versão otimista, era a de que o índice de volatilidade eleitoral apresentasse uma curva temporal decrescente: nos pleitos iniciais da transição democrática ter-se-ia alta flutuação eleitoral, ao passo que com a estabilização política, social e econômica, os partidos estabeleceriam laços mais fortes com o eleitorado.

A agenda de estudos produzida com a "terceira onda de democratização" representou, de certa forma, uma renovação no papel conferido aos partidos para a manutenção da ordem democrática, após as conclusões de um conjunto da literatura que concedia papel secundário aos agrupamentos partidários nas configurações políticas européias atuais (ver, entre outros, Dalton, 2004). Pretendo aqui selecionar alguns pontos para debate, encontrados na literatura recente.

A noção de institucionalização utilizada por parte da literatura comparada é em grande medida caudatária daquela formulada por Huntington, discutida na seção anterior. O sistema partidário, dentro dessa perspectiva, seria institucionalizado se 
canalizasse as demandas e os conflitos da sociedade nas instituições políticas, apresentando eficazmente funções representativas e governativas. Em Mainwaring e Scully (1994) tem-se um dos principais textos que, se pautando em parte nesse cabedal teórico, utiliza o índice de volatilidade como medida empírica central. Os autores afirmam que estudos sobre o sistema partidário na América Latina devem se atentar para as diferenças nos graus de institucionalização, quando comparados com os europeus. Discutem assim o índice de volatilidade, entre outras evidências, para defender a tese de que os primeiros, os partidos latino-americanos, são menos institucionalizados que os seus congêneres europeus. Assinalam, ainda, que existe uma marcada variação dentro do continente: dentre os países com sistemas partidários incipientes, pouco institucionalizados, têm-se a Bolívia, o Peru, o Equador e o Brasil. No que diz respeito principalmente ao último, os autores dizem: "vários estudos sobre atitudes políticas e comportamento eleitoral no Brasil mostram que a maioria dos cidadãos não manifesta preferências partidárias e seu padrão de voto, especialmente para cargos importantes do Executivo, não é determinado pela predileção por organizações partidárias" (Mainwaring e Scully, 1994: 54). Os autores assinalam os perigos de se ter um sistema partidário pouco institucionalizado: propensão ao populismo e ao "pretorianismo" (um conceito de Huntington), déficit de accountability, legitimidade e governabilidade.

Em um texto mais recente de Mainwaring, agora em co-autoria com Torcal, novamente está presente a questão da institucionalização do sistema partidário na América Latina. As discussões teóricas, bem como os indicadores empíricos utilizados, são semelhantes aos mobilizados pelo texto anterior de Mainwaring e Scully. No que diz respeito à volatilidade, a inclusão de pleitos mais recentes mostra que a flutuação do voto diminuiu no Brasil: se no período 1982-1990 era de 40,9 \% (Mainwaring e Scully, 1994: 48), no período 1986-2002 foi de 24,1 (Mainwaring e Torcal, 2005: 257). A comparação desse índice com outros casos nacionais ${ }^{23}$ levou os autores a testarem a hipótese da importância do nível de desenvolvimento econômico para a estabilidade das preferências eleitorais. Os testes de correlação indicaram haver associação negativa entre o índice de volatilidade e o PIB per capita, e entre volatilidade e o IDH. A possível

\footnotetext{
${ }^{23}$ A amostra inclui os EUA, países da América Latina, da Europa Ocidental e Oriental e asiáticos.
} 
causalidade que poderia ser atribuída é, entretanto, mitigada. Conforme afirmam os autores:

"Na maioria do que agora são democracias industriais avançadas, os partidos foram veículos de integração social e políticas das massas de novos cidadãos (...). Na maioria dos países de democratização tardia, os partidos ocuparam um lugar menos central na luta para expandir a cidadania e nunca tiveram as funções sociais de amplo alcance ou fomentaram fortes identidades" (Mainwaring e Torcal, 2005: 259).

Ou seja, a correlação entre desenvolvimento e flutuação do voto pode ser espúria, e esta talvez possa ser melhor compreendida como efeito da contingência política de cada país.

Se essa interpretação for levada às últimas conseqüências, temos que não há uma relação necessária entre institucionalização do quadro partidário e democracia. Entretanto, nas conclusões, sempre retorna a questão da relação entre partidos e democracia nas configurações contemporâneas. No final do texto, os autores afirmam que:

"se a história política moderna está alicerçada sobre os partidos políticos, então podemos esperar que a democracia apresente algumas deficiências onde os partidos são mecanismos menos estáveis de representação, accountability e estruturação do que foram nas democracias industriais avançadas" (Idem: 276).

Ao mesmo tempo que os autores afirmam que seria irrealista exigir os mesmos padrões partidários em países que passaram por experiências históricas distintas, afirmam que a democracia, para funcionar sem "deficiências", exige como condição necessária a existência de partidos e sistemas partidários tal como, podemos dizer, o modelo de partidos de massas na Europa ${ }^{24}$.

Logo, se for assim, os países não centrais parecem se encontrar numa encruzilhada: a despeito de adotarem o regime democrático, não alcançarão seu pleno

\footnotetext{
${ }^{24}$ Embora não tratem nesses termos explicitamente, pode-se deduzir que as características impressas ao modelo partidário das "democracias industriais avançadas" encontram forte paralelo com o modelo do partido de massas, tal como teorizado por Duverger (1987), por exemplo.
} 
funcionamento, devido aos seus percalços históricos. Em outros termos, não importa a virtu que apresentem, sempre serão servos de sua fortuna ${ }^{25}$.

Outro conjunto de literatura apresenta uma perspectiva analítica razoavelmente diversa. Ainda que motivado pela discussão sobre a consolidação da democracia na América Latina (e na Europa do Leste), buscam as causas das taxas de volatilidade, antes que, a partir dela, fazer interpretações sobre o sistema político. Para isso, testam três hipóteses derivadas de três teorias sobre sistemas partidários e comportamento eleitoral: a tese do voto econômico, a tese das clivagens sociais, e a visão institucionalista. Como exemplos dessa literatura, podemos citar Roberts e Wibbels (1999) e Tavitis (2005).

O objetivo desses estudos é ponderar o peso das variáveis oriundas de diferentes teorias sobre a volatilidade, notadamente o impacto do crescimento econômico e da inflação, o papel das clivagens, a la Lipset e Rokkan, e a estruturas e as mudanças do sistema político, partidário e/ou eleitoral. A metodologia utilizada, via de regra, são regressões lineares, cuja variável dependente é o índice de volatilidade de Pedersen e as independentes são indicadores das três teorias. Ambos os estudos, de Roberts e Wibbels calcado na América Latina, e de Tavits no Leste Europeu, concluem pela importância principal do voto econômico e dos constrangimentos institucionais, em detrimento das clivagens sociais. Rennó, Peres e Ricci (2011) constitui um exemplo de abordagem semelhante, mas focado no caso brasileiro. Os resultados econométricos dos autores apontam que a migração partidária, a renovação parlamentar e o analfabetismo impactam positivamente a volatilidade, enquanto que e a proporção da força de trabalho com carteira assinada influencia negativamente.

A experiência democrática brasileira de 46-64 ensejou uma série de estudos sobre o funcionamento do sistema partidário, e as discussões, embora raramente utilizassem explicitamente a volatilidade eleitoral, tocavam no debate teórico que está por trás do índice, particularmente na avaliação sobre em que medida o sistema partidário passava por processos de instabilidade que levariam ao golpe de 64 .

\footnotetext{
${ }^{25}$ Mainwaring e Zoco (2007) focam diretamente nessa questão, e reforçam a idéia de que a estabilidade do sistema partidário está ligado a ao período histórico de instalação do sistema democrático.
} 
Uma das hipóteses centrais na literatura é o crescimento contínuo dos partidos não-conservadores, notadamente o PTB, fruto, principalmente, do avanço dos processos de industrialização e urbanização no Brasil dos anos 50 e 60. Figueiredo (1995) utiliza o índice de volatilidade de Pedersen ${ }^{26}$ para verificar em que medida ocorria processos de instabilidade e realinhamento eleitoral no período, além de avançar nessa mesma discussão para o período bipartidário de 66 a 78. O autor elenca três hipóteses que explicariam a volatilidade: além das variáveis institucionais e sociológicas, que estão presentes nos estudos comparados, Figueiredo (1995: 125) levanta também variáveis políticas: "tais como mudanças sensíveis no discurso e comportamento dos partidos e experiência governativa de um ou mais partidos, em governos de coalizão". Aqui o autor chama atenção para o impacto das estratégias partidárias e do comportamento das elites políticas na volatilidade eleitoral, variáveis que também considero importantes e que utilizarei para pensar meu objeto. Os resultados apresentados pelo autor confirmam a tese de realinhamento do sistema partidário pré-64, com o fortalecimento das legendas não-conservadoras, efeito de fatores sociológicos, assim como a importância de variáveis institucionais e políticas na mobilização eleitoral do MDB e da ARENA nos anos 70 .

Lavareda (1991) estabelece um diálogo crítico com as visões dominantes sobre a democracia de 46, especialmente com as teses que estabelecem como uma das causas do golpe de 64 a desestruturação do sistema partidário. A partir de uma visão mais global do sistema e da competição partidário-eleitoral, o autor defende que nossa primeira experiência democrática não sofreu processos de desarticulação e instabilidade partidária, antes o contrário, apresentando, às vésperas de sua queda, elevados indícios de consolidação, no que diz respeito a relação eleitor-partido.

Nicolau (2004), empreendendo movimento teórico semelhante ao de Lavareda, também propõe a revisão de algumas teses da literatura sobre 1946, e, dentre outras coisas, calcula o índice de volatilidade eleitoral para as eleições parlamentares, buscando testar proposições sobre a fragmentação do sistema partidário. Diferentemente de outros estudos, o autor utiliza dados eleitorais desagregados por partido. O demonstra que no nível da estruturação das preferências do eleitorado não havia

\footnotetext{
${ }^{26} \mathrm{Na}$ verdade, devido à dificuldade de obtenção dos dados, o autor trabalha com cadeiras conquistadas, $\mathrm{e}$ não com votos.
} 
volubilidade ou instabilidade eleitoral. Os índices encontrados, de fato, são muito mais baixos que a volatilidade legislativa atual ${ }^{27}$.

Ainda voltado para o período de 46 , Souza realiza um estudo não preocupado com a institucionalização partidária, mas antes com discussões sobre as teorias do comportamento eleitoral. Seu objetivo é testar duas proposições advindas de duas teorias diferentes sobre o eleitor flutuante: de um lado, a teoria da escolha racional, que afirma que os cidadãos decidem seu voto com base nos diferenciais partidários ${ }^{28}$; de outro lado, a sociologia e a psicologia política, que ressaltam que a decisão eleitoral é pautada pelo alinhamento, ou conformismo, dos eleitores com seus grupos sociais ${ }^{29}$. Souza afirma que o eleitor flutuante, de acordo com a primeira visão, é racionalmente movido a mudar suas preferências eleitorais fruto da avaliação do governo; para a segunda visão, o volátil é o indivíduo isolado socialmente, alvo de pressões cruzadas, destoante do alinhamento partidário. Sua análise de dados do pleito presidencial de 1960 leva-o a concluir que: "explicações baseadas em uma teoria racional do comportamento político são mais simples, mais fecundas e mais intuitivas do que aquelas fundadas em teorias que concebem a ação política como resultante de determinismos sociais" (Souza, 1972: 145).

Vemos assim que a preocupação com a institucionalização partidária ocupa papel proeminente na análise da democracia de 46, motivada pela busca de explicações para a crise da democracia em 64 . O conhecimento acumulado permite afirmar que, no nível do eleitorado, os partidos políticos encontravam-se razoavelmente estabilizados. Por outro lado, discussões sobre as causas da volatilidade, bem como sobre teorias do comportamento eleitoral também se fizeram presentes.

O debate mais forte com a literatura sobre volatilidade eleitoral surge, em verdade, na experiência democrática atual. O ocaso da ditadura militar nos anos 80, com a abertura partidária, a promulgação da Constituição em 1988 e as eleições diretas pra presidente em 1989 ensejaram uma grande literatura na Ciência Política preocupada

\footnotetext{
${ }^{27}$ A média nacional do período de 1945 a 1962 é $12 \%$ de volatilidade. No estado de São Paulo, a média é maior: $25 \%$.

${ }^{28}$ A referência aqui é Downs (1999).

${ }^{29}$ As referências aqui são Campbell et alii (1980) e Lazarsfeld et alii (1948).
} 
com o papel dos partidos políticos na arena eleitoral, suas estratégias e relações com o eleitorado. As pressuposições iniciais, dado o arcabouço empírico e analítico produzido pelos estudos de Reis, Lamounier, entre outros, criou a expectativa tácita de que a volatilidade seria alta. Seguem-se alguns estudos.

Nicolau (1998) estuda a volatilidade nas eleições para o legislativo federal e estadual de 1982 a 1994. Além de estabelecer correlações entre os diferentes índices encontrados, tanto entre os Estados, quanto numa perspectiva temporal, o autor discute relações causais, testando duas hipóteses: a de que o aumento no número de partidos e o aumento da migração partidária impactam positivamente na volatilidade eleitoral. Suas conclusões apontam a importância do fenômeno da última variável para explicar a volatilidade. Ou seja, alude-se a possibilidade de que o eleitor vota no candidato individual, independente de qual partido este se encontre.

Alguns autores defendem a tese de que os partidos brasileiros passam por processos de institucionalização. Dentre esses, destacam-se Peres e Braga. O primeiro propõe uma ampla revisão de vários conjuntos de literatura sobre instabilidade política, "pretorianismo", ingovernabilidade que incidiram, de uma maneira ou de outra, num julgamento sobre a democracia no Brasil. A intenção de Peres (2000) é mostrar que existe um "espectro da instabilidade" que ronda as discussões sobre o papel dos partidos no sistema político atual, espectro este que seria influenciado por visões dominantes do pensamento social brasileiro, da política comparada, das teorias de desenvolvimento político e do neo-institucionalismo. O objeto empírico do autor são os pleitos para a Câmara dos Deputados, entre 1982 e 1998, utilizando tanto a volatilidade partidária (ou seja, os partidos como nível de análise), quanto a volatilidade ideológica (por blocos de partidos, como defendeu Bartolini e Mair). As conclusões de Peres (2000: 151) são que:

"nosso sistema partidário ainda está em processo de institucionalização e sua instabilidade é relativamente elevada quando comparada aos sistemas europeus. Contudo, a estabilidade é significativa e indica claros avanços na capacidade dos partidos competirem por votos de maneira coerente, estruturando as preferências políticas e estabilizando o comportamento eleitoral segundo um ordenamento ideológico".

Braga (2006) busca elaborar um quadro analítico que apreenda a dinâmica do sistema partidário brasileiro de 1982 a 2002. No que concerne à volatilidade eleitoral, a autora defende a hipótese de que "as relações entre sistema partidário e preferências eleitorais não são mutuamente equivalentes. Nesse sentido, outros fatores, como a 
mudança no comportamento das elites, nas estratégias partidárias (...), explicam, em grande medida, o grau ou não de estabilidade do sistema partidário" (Braga, 2006: 2056). A tese da autora é que a evolução partidária brasileira deve ser entendida como a passagem "lenta e gradual" do bipartidarismo, que após 1979 deixou de ser compulsório, mas continuou a se revelar na prática, para o multipartidarismo, nos diferentes distritos eleitorais. As legendas oriundas do período ditatorial, notadamente o PMDB e o PDS (hoje PP), além do PFL e PSDB, fissões dessas, entraram no pós-82 com amplos recursos políticos e organizacionais, postergando a emergência de outros partidos competitivos em determinados estados. As mudanças do sistema partidário nos anos posteriores são vistas, pela autora, como movimentos em direção ao equilíbrio com a entrada de novos partidos, ou, nas suas palavras, "como o processo de estruturação do multipartidarismo".

Dentre as posições mais críticas ao nosso sistema partidário na sua relação com o eleitorado, destaca-se Kinzo (2007: 20). A autora assinala sua motivação:

"mesmo admitindo que os partidos e o sistema partidário no Brasil tenham tido um desempenho satisfatório no que tange tanto à sua função governamental como à sua função de servir os objetivos eleitorais da elite política, permanece uma questão a ser examinada: o quão efetivo eles são em seu papel de orientar os cidadãos na decisão do voto”.

Kinzo propõe a análise do sistema partidário sob o ponto de vista do eleitor, na forma como os laços partidários envolvem os cidadãos. Além do índice de identificação partidária, a autora utiliza o indicador de volatilidade eleitoral para examinar essa questão, e afirma que, diferentemente da argumentação de Peres (2000) e Braga (2006), a flutuação eleitoral no Brasil é alta e não tende a declínios com o passar do tempo. As estratégias dos partidos, condicionadas pela estrutura de incentivos dada pelas instituições político-eleitorais, não leva o eleitor a diferenciar as legendas partidárias (à exceção do PT). Os laços partidários constituídos seriam tênues e a disputa política passível de volubilidade.

Cabe ressaltar que os resultados dos indicadores, como seria de se esperar, pouco diferem de autor para autor. As interpretações divergentes, assim, são fruto ou do alcance da série temporal da volatilidade considerada, ou de julgamento sobre o que seria a volatilidade "aceitável" e o quanto o caso brasileiro foge do esperado, ou da avaliação com base em tendências de curto prazo. 
O trabalho de Bohn e Paiva (2009) apresenta uma especificidade importante para a proposta da presente pesquisa. As autoras calculam o índice de volatilidade eleitoral tanto para os cargos legislativos (deputado federal, estadual e senador) quanto executivos (presidente e governador), desagregada por unidades da federação, de 1982 a 2006. A comparação entre esses cargos leva as autoras a afirmarem que os pleitos majoritários são significativamente mais voláteis que os proporcionais, um resultado que seria contra-intuitivo, visto que as últimas apresentam muito mais opções de escolha para o eleitorado, sendo, portanto, mais fácil para este mudar a direção do seu voto. Bohn e Paiva aludem a possível explicação, lançando a agenda sobre pesquisas futuras: "cabe-nos analisar o quanto as mudanças na oferta eleitoral afetam a volatilidade eleitoral" (Idem). As autoras se referem à questão do formato de partidos, nas palavras de Pedersen, ou da coordenação pré-eleitoral, nas palavras de Cox (1997), que é principal variável que pretendo utilizar nas análises.

O trabalho de Lima (1996) é importante para a presente discussão por três motivos: seu objeto é a capital paulista, foca nos cargos majoritários ${ }^{30}$ e executivos e toca na questão do comportamento eleitoral e da representação política ${ }^{31}$. O objetivo do autor é buscar dissimilaridades entre as classes sociais no que diz respeito à volatilidade eleitoral, calculando a variação do índice conforme as áreas homogêneas da cidade. Os resultados do autor mostram que não existe um padrão social claro para a mudança na direção do voto: ora os mais abastados são mais volúveis, ora as classes mais populares.

Ainda focando na capital paulista, os sucessos eleitorais do PDS com Maluf na cidade foram objeto de análise de Pierucci e Lima (1991 e 1993). No pleito para governador em 1990, Maluf, a despeito de ser derrotado para Fleury do PMDB, fica em primeiro lugar na capital do estado nos dois turnos. Pierucci e Lima notam que esse desempenho, impensável aos analistas políticos até pouco tempo antes, foi possível com a incorporação, à tradicional base eleitoral conservadora (notadamente os bairros da Zona Leste e Norte próximos ao Centro), das regiões mais abastadas da cidade. A tese

\footnotetext{
${ }^{30}$ Cabe notar que o autor não faz muitas considerações a favor dessa escolha metodológica. Ao contrário, afirma que os dados para as eleições legislativas não estavam desagregados por zonas eleitorais, impossibilitando o uso que pretendia, e chama a atenção para o fato de que eleições para cargos executivos são carregadas de mais personalismo, podendo enviesar a análise (Lima, 1996: 27).

${ }^{31}$ A referência aqui é Manin (1995), que aponta para as mudanças sofridas pela representação política na contemporaneidade.
} 
dos autores é que esse movimento da classe média e classe alta é fruto de um voto útil com vistas a barrar o crescimento eleitoral da esquerda, representada pelo PT. Tanto em 1988, quanto em 1990, o grupo mais rico da cidade flutua seu voto, partindo do PSDB para se aproximar do PDS: "lealdade e consistência, fidelidade e enraizamento (...) fazem cada vez menos parte do comportamento eleitoral normal dos estratos médios superiores, mais bem instalados na cidade e mais bem informados" (Pierucci e Lima, 1991: 25). Entretanto, essa volatilidade eleitoral dos setores mais elevados socialmente permite, por definição, que a direita perca a hegemonia recém conquistada, desde que exista uma moderação na plataforma da esquerda.

A posição dos autores parece se modificar um pouco quando da eleição de Maluf para prefeito em 1992. A configuração crescente de sua votação, conforme os estratos sociais, faz os autores relembrarem-se da base social da ARENA nos anos 70. Assim, o que antes parecia volátil, podia ser na verdade o retorno do capital eleitoral conservador na capital:

"[ Em 88] era o primeiro ato de um realinhamento de bases eleitorais que a princípio pareceu meramente conjuntural, pois se tratava de algo muito espontâneo e veloz, um surto agudo de conservadorismo ativo ante a disparada petista de última hora. Hoje, olhando em retrospectiva, aparece como uma coligação desde abajo muito bem sucedida" (Pierucci e Lima, 1993: 96) ${ }^{32}$.

\section{Síntese}

Essa seção tem objetivo realçar alguns dos caminhos analíticos percorridos por parte da literatura que lidou com o conceito de volatilidade eleitoral no Brasil. Como forma de resumir esse pequeno balanço, no anexo se encontra um quadro com a síntese da literatura aqui discutida. A intenção não é perpassar toda a literatura produzida, mais chamar atenção para as discussões e as conclusões mais gerais que cada texto apresenta, buscando cobrir um leque de alguns caminhos analíticos percorridos.

\footnotetext{
${ }^{32}$ Limongi e Mesquita (2008: 53) também notam que a força eleitoral de Maluf e do PDS (hoje PP) nessas disputas e nas subseqüentes deixa de ser surpreendente se se nota a considerável base de apoio conservadora em São Paulo desde 1982.
} 


\section{Capítulo II - Ligação eleitor - partido}

Como vimos, o debate da volatilidade está assentado, em grande medida, em discussões no nível sistêmico dos partidos e dos eleitores. No entanto, muitos de seus aspectos fazem referência, por vezes implícita, ao comportamento individual dos votantes. Esta seção tem por objetivo abordar mais detidamente esse ponto, voltando-se para a literatura das teorias do comportamento eleitoral. Costuma-se dividi-las em três diferentes paradigmas: a abordagem sociológica, a psico-sociológica e a da escolha racional. Discutirei alguns aspectos de cada uma dessas teorias, as compreensões que trazem sobre a relação entre partido-eleitor no tempo e certos desenvolvimentos na literatura brasileira. Dois são os objetivos principais: discutir as implicações das diferentes teorias do comportamento eleitoral na visão que se tem sobre o eleitor volátil e o estável, ressaltando a predominância dos conceitos oriundos da sociologia e da psico-sociologia no debate sobre volatilidade, e sugerir os ganhos analíticos que a incorporação de instrumentos da escolha racional podem trazer para se pensar o fenômeno da volatilidade.

\section{Sociologia Eleitoral}

A visão sociológica do voto foi sistematizada nos anos 40 por trabalhos dirigidos por Lazarsfeld em Columbia e, desde então, influencia fortemente as discussões sobre comportamento eleitoral. A suposição desses estudos, de acordo com Figueiredo (1991: 43), está na afirmação de que "não são os indivíduos e sim os coletivos sociais que imprimem dinâmica à política; e o que precisa ser explicado são os resultados agregados de ações coletivas". Nas palavras de Castro (1992: 14)

"a idéia é de que os fatores histórico-estruturais e culturais globais conformam as características sociais, econômicas e políticas de uma sociedade, gerando determinadas clivagens sociais que se expressam através de partidos específicos, com os quais setores do eleitorado se identificam". 
O comportamento político teria então como causa primordial variáveis sociais, contextuais, macro: classe social, religião, lugar de residência, gênero, etc. são a unidade de explicação ${ }^{33}$.

O centro da argumentação sobre a relação entre clivagens sociais e partidos políticos, tal como formulada por Lipset e Rokkan e que marca o debate da volatilidade, contém forte paralelo com a perspectiva sociológica do comportamento eleitoral.

Dos primeiros trabalhos da teoria sociológica do voto destaca-se The People's Choice, escrito por Lazarsfeld, Berselson e Gaudet. A obra busca compreender o comportamento político por meio da formação de opiniões. Qual é o processo social que explica a decisão do voto? A campanha determina sua direção? Os eleitores flutuam ou mudam de intenção de voto?

A tese encampada por Lazarsfeld e outros é de que predisposições sociais dos indivíduos já direcionam suas preferências políticas, previamente às questões da campanha vigente. Isso ocorre mesmo sem consciência dos eleitores, que muitas vezes afirmam nos primeiros períodos da campanha que não decidem de antemão qual partido sufragar. As explicações para a influência dos grupos sociais repousam, grosso modo, em dois registros: o primeiro é a noção de que comportamentos agregados não podem ser reduzidos à mera soma de atos individuais, antes teriam propriedades próprias. $\mathrm{O}$ outro ponto é a influência dos líderes de opinião, que são capazes de constranger o comportamento dos membros dos grupos (famosa teoria do two-step flow). Assim, os autores acreditam que "a person thinks, politically, as he is, socially. Social characteristics determines political preference" (Lazarsfeld et alii, 1948: 27).

Um importante conceito relacionado à força do grupo é o de pressões cruzadas. Como nas sociedades modernas a complexificação social tem importante papel, é de se esperar que indivíduos pertençam a grupos de orientação política divergente. Assim, essas pressões cruzadas podem levar alguns cidadãos a apresentar comportamentos políticos inconsistentes. Dito de outra forma, a argumentação consiste em ressaltar que

${ }^{33}$ Pode-se dizer que algumas abordagens trazem o mecanismo de passagem do nível macro para micro, como por exemplo, as interações sociais, ou a consciência de classe, mas, de modo geral, essa corrente está fortemente baseada em deduções do comportamento individual a partir de variáveis agregadas. Para uma defesa epistemológica do mecanismo como explicação causal e do individualismo metodológico ver Elster (1994). 
configurações estruturais-sociais são determinantes para a possível existência de uma unidimensionalidade no comportamento político, assim como de uma estruturação das preferências eleitorais.

Assim, a caracterização que os autores fazem do eleitor volátil é de tom crítico e negativo: "the notion that the people who switch parties during the campaign are mainly the reasoned, thoughtful, conscientious people who were convinced by the issues of the election is just plain wrong" (Lazarsfeld et alii 1948: 63). As pessoas que decidem seu voto à última hora, ou que mudam a direção do mesmo, ou que apresentam pouco interesse pelas eleições e por isso não comparecem às urnas agem assim porque não apresentam vínculos fortes com comunidades sociais. São marginalizados socialmente, pode-se dizer. Os eleitores constantes, ao contrário, "were reported to be more selfassured, better informed, more cooperative, and broader in their interest" (Lazarsfeld, 1948: 70).

Vê-se, assim, que a explicação para o eleitor instável está calcada na ausência dos fatores que essa teoria postula como sendo determinantes do comportamento eleitoral: o pertencimento aos grupos sociais e suas interações. Ademais, a visão sobre o fenômeno da volatilidade possui caráter fortemente normativo, no sentido de que o cidadão "ideal” para a democracia deveria apresentar comportamento eleitoral estável.

Outro conjunto de literatura, em parte de inspiração marxista, foca mais fortemente na importância eleitoral da clivagem de classe. Marx, na sua obra 18 de Brumário de Luís Bonaparte, analisa os partidos e os agrupamentos políticos da França do século XIX na sua relação com os grupos e as classes sociais. Lipset (1975: 231), em outro registro, diz que "em todas as democracias modernas, o conflito entre diferentes grupos é expresso através dos partidos políticos que representam basicamente uma tradução democrática da luta de classes ' ". Assim, essa abordagem ressalta a correlação existente entre estratificação sócio-econômica e apoio a diferentes ideologias políticas. Novamente aqui cabe ser relembrada a associação entre essa teoria do comportamento eleitoral e as abordagens da área da volatilidade eleitoral: nesta, é constantemente afirmado que a clivagem política mais importante é a classista (cf. Bartolini e Mair, 1990).

Na literatura nacional, a perspectiva sociológica do comportamento eleitoral fezse (e faz-se) muito importante. Como alguns exemplos focados no caso de São Paulo, 
têm-se o trabalho de Simão (1956) e Weffort (1965) sobre estruturas sociais e partidos na república de 46. No primeiro, a tese defendida é de que PTB e PCB, partidos de cunho trabalhista e socialista, respectivamente, encontraram maior apoio eleitoral nas regiões de bairros operários. No segundo, consistia-se em entender, de um ponto de vista de inspiração marxista e no modelo de consciência de classe, a força de Adhemar de Barros e Jânio Quadros na capital paulistana.

Nos anos 70, as pesquisas organizadas por Lamounier e Cardoso e Reis utilizaram-se dos arcabouços da sociologia eleitoral para a compreensão das disputas políticas daquele período, bem como os livros organizados pelo IDESP (Instituto de Estudos Econômicos, Sociais e Políticos) durante os anos 80, que retrataram as bases eleitorais do PMDB e a impressionante estabilidade geográfica das de Jânio Quadros.

No pós-88, além dos já discutidos trabalhos de Pierucci e Lima (1991, 1993) sobre o crescimento eleitoral da direita na cidade de São Paulo, Singer (1990) analisa a performance de Collor na periferia, Novais (1996) propõe uma divisão da cidade de acordo com sua geografia eleitoral e Limongi e Mesquita (2008) reconstituem a história eleitoral com base nos partidos concorrentes e nos perfis de apoios recebidos.

De modo geral, a literatura sociológica foca nos condicionantes sociais do comportamento eleitoral e defende que determinadas clivagens ou grupos sociais moldam a relação partido-eleitor por meio de relações e laços de natureza razoavelmente perene. O comportamento volátil ou flutuante é explicado, então, no plano individual, pela ausência de pertencimento ou reconhecimento a grupos sociais, e/ou, no plano coletivo, como fruto de situações de grandes mudanças estruturais nas quais a representação política perde suas bases tradicionais.

As discussões teóricas da sociologia eleitoral motivam dois testes analíticos, a serem realizados na parte empírica deste trabalho. Primeiro, verificaremos se mudanças na direção partidária do voto estão associadas a níveis sociais dos indivíduos. Segundo, analisaremos se os partidos se diferenciam na sua base social de apoio, e se essa diferenciação se coaduna com as divisões ideológicas atribuídas aos partidos. Ou seja, se agremiações mais à esquerda estão assentadas nos mais pobres, em comparação relativa com as legendas mais à direita. 


\section{A escola de Michigan e a psico-sociologia}

A corrente psico-sociológica do comportamento eleitoral, também chamada escola de Michigan, se constrói, em parte, como uma crítica a alguns pressupostos da abordagem sociológica e, em outra, recebendo influência de desenvolvimentos na área de psicologia social e política. Ressalta a importância do indivíduo e, especificamente, sua apreensão, compreensão e avaliação do mundo político. Uma obra marca seu período inicial, nos anos 60: The American Voter, escrito por Campbell, Converse, Miller, e Stokes.

Logo no início do texto, Campbell e outros afirmam que "the project represented a shift in emphasis from explanation in sociological terms to the exploration of political attitudes that orient the individual voter`s behavior in an immediate sense" (Campbell et alii, 1980: 16). A crítica se volta contra a dedução do comportamento político baseada em pressupostos ontológicos da sociologia. Os macro-fatores como classe social, religião, raça e as variáveis institucionais, como sistema partidário e sistema eleitoral, influenciariam indiretamente a decisão do voto. Todos passam por uma espécie de filtro cognitivo do indivíduo, onde na ponta se encontra o sistema de crenças de cada eleitor. Segundo Figueiredo (1991: 23), para essa teoria, “o sistema atitudinal não é cativo de grupos ou classes sociais". No entanto, isso não evita, obviamente, que condicionantes sociais interfiram no campo psicológico dos indivíduos de modo geral, e no comportamento eleitoral de modo específico. Antes, "os sentimentos do eleitor sobre partidos, problemas e candidatos não surgem por geração espontânea (...), formam-se pela interação entre a estrutura psicofísica do eleitor e seu ambiente físico e social" (Bone e Ranney, 1966: 22).

Como exemplo, na literatura nacional, de estudos que parte dessas proposições, tem-se a coletânea editada por Reis (1978), onde o comportamento eleitoral brasileiro foi estudado em diferentes contextos municipais por meio de entrevistas, visando capturar determinantes sociais e psicológicos da direção do voto.

O conceito-chave que sintetiza as influências psicológicas sobre a política é a Identificação Partidária (IP). A inscrição da IP nos indivíduos, por meio do processo de socialização, consiste numa adesão atitudinal aos partidos políticos: "Generally, this tie is a psychological identification, which can persist without legal recognition or evidence of formal membership" (Campbel et alii, 1980: 121). A funcionalidade do sistema 
democrático moderno residiria então não no indivíduo racionalmente engajado na política, mas na criação de vínculos de identidade entre partidos e cidadãos. Mais do que isso, a IP configura ainda "an important factor in assuring the stability of the party system" (Idem: Ibidem). Esse fator de estabilidade do sistema partidário é fruto da estabilidade mesma da IP. A orientação recebida no período de socialização implica que a ligação psicológica entre indivíduos e partidos assume "great stability between elections" (Idem: 121).

A disputa eleitoral, logo, pode ser entendida como uma campanha por mobilização dos eleitores identificados com cada partido de um lado, e uma busca por aqueles com fraca ou nenhuma identificação. Um sistema político consolidado, que perfaz uma situação na qual a maioria de seus cidadãos possua IP, resultaria em pequena flutuação no resultado eleitoral de eleição para eleição.

Falando mais detidamente do eleitor volátil, a caracterização que a escola de Michigan faz deste tipo de comportamento é pejorativa, crítica. Lima (1996: 22) observa que "uma das origens (...) [do] conceito negativo da volatilidade está nos estudos desenvolvidos nas décadas de 50 e 60 pelos pesquisadores da Universidade de Michigan (...). A volatilidade foi associada aos eleitores periféricos”. Quando falam do eleitor que se diz independente, e que também é o que mais muda seu voto, Campbell et alii (1980: 143) afirmam que "the ideal of the independent citizen, attentive to politics, (...) who weighs the rival appeals of a campaign and reaches a judgment that is unswayed by partisan prejudice" não é encontrado em suas pesquisas. Antes, "they have somewhat poorer knowledge of the issues, their image of the candidates is fainter".

Empiricamente, como afirma Figueiredo (1991: 39) “é a variável educação que comanda a relação entre classe e identidade partidária devido a sua importância na formação dos níveis de conceituação da política". O nível educacional, diretamente ligado com a capacidade cognitiva, é o fator mais importante a explicar o desenvolvimento de IP. Portanto, os indivíduos de menor educação tendem, de acordo com essa teoria, a apresentar menor IP e maior volatilidade eleitoral. Do ponto de vista do governo democrático, a existência de muitos eleitores voláteis e de pouca ou sem IP 
(os dois termos são praticamente sinônimos) é visto como uma dificuldade para seu bom funcionamento ${ }^{34}$.

No que se refere ao Brasil, esses dois conjuntos de proposições teóricas, IP e sistema de crenças, permearam os primeiros estudos eleitorais brasileiros, que buscavam compreender as motivações psicológicas do voto ao MDB e as possibilidades de apoio a um futuro regime democrático. As evidências apontavam que grande parcela da população possuía IP (principalmente com o MDB), mas os dados empíricos também sublinhavam as bases rudimentares em que as preferências partidárias estavam alicerçadas: ao invés de coerência quanto aos assuntos políticos, os autores concluem que a identificação se dava em base de imagens toscas e difusas ${ }^{35}$.

No final da transição e na abertura do quadro partidário, as expectativas colocadas por boa parte da literatura nacional era a de que a movimentação das elites no sentido de dispersão das agremiações partidários traria dificuldades ao comportamento político das massas, pois estas perderiam a "coerência" imposta pelo sistema bipartidário forçado. O momento eleitoral, então, seria marcado por uma crescente volubilidade (Lamounier, 1994: 39), pois os eleitores não agiriam guiados por laços partidários.

Mais recentemente, autores como Kinzo (2004; 2007), preocupados eminentemente com a questão da representação, procuram estudar a capacidade dos partidos em criar laços e imagens no eleitorado, ressaltando a debilidade na consecução desse objetivo; Carreirão e Kinzo (2004), discutindo a identificação partidária, levantam a interessante hipótese de que esta poderia ocorrer pela via negativa: grande parcela dos eleitores rejeita partidos, e, logo, não os sufragam. Singer (2000) defende a famosa hipótese da importância do voto ideológico no comportamento eleitoral brasileiro, entendido esse como uma identificação intuitiva captada por auto-localização numa escala esquerda-direita. Castro (1992) utiliza o conceito de sofisticação política para

\footnotetext{
${ }^{34}$ Converse (1979) estabeleceu o conceito de sistema de crenças para compreender a consistência do comportamento político dos cidadãos (para uma discussão bibliográfica desse conceito, ver Rennó, 2001). As pesquisas empíricas ressaltavam que a grande maioria do eleitorado não se guiava por um sistema de crenças estruturado em nível ideológico clássico, como esquerda x direita, liberal x conservador, etc., antes seguia ordenações idiossincráticas.

${ }^{35}$ Cabe notar que, diferentemente do que propõe a literatura clássica de Michigan, os achados no Brasil afirmam que pessoas de menor educação tendiam a ter maior grau de identificação partidária.
} 
apreender os diferentes tipos de eleitores, concentrando-se na aquisição, no uso e na qualidade das informações políticas por eles mobilizadas. Silveira (1996) compara o comportamento do eleitor brasileiro atual com o passado, e propõe a tese de que à diferença de outrora, o eleitorado hoje não é mais cativo de grupos políticos, apresentando comportamentos voláteis, flutuantes e instáveis, devido principalmente a mudanças na estrutura social. No entanto, semelhantemente ao passado, esse comportamento é pautado por fatores não-racionais, impulsionados agora pela importância da televisão e do marketing eleitoral.

Vemos, assim, que o paradigma sócio-psicológico influenciou o debate brasileiro, principalmente por meio das visões "psicologizantes" da identificação partidária, ideologia, apreensão do mundo político, capacidade cognitiva e sofisticação política. Nas visões mais correntes estabelece-se que os resultados eleitorais brasileiros seriam altamente imprevisíveis, pois os níveis de IP baixaram desde o fim da ditadura e os níveis educacionais apresentaram pouca melhora, dificultando elevação no nível de sofisticação política e aumentando, portanto, a volatilidade eleitoral.

\section{A escolha racional e o comportamento eleitoral}

Modelos de comportamento político baseados escolha racional se diferenciam dos anteriores por ressaltarem o caráter instrumental da competição eleitoral. Aqui, as preferências dos eleitores não são formatadas numa esfera psicológica, herdada de um esfera pré-política, como no modelo Michigan, ou constrangidas pelo o grupo social, como na teoria sociológica. Antes, a escola da escolha racional afirma que eleitores votam de acordo com seus interesses pessoais, seja julgando o desempenho passado do governo (voto retrospectivo), seja apostando na sua performance futura (voto prospectivo).

A visão inicial e principal da escola racional sobre comportamento eleitoral foi dado por Downs na Teoria Econômica da Democracia, livro de 1957. O autor buscou compreender o comportamento de partidos, do governo e dos eleitores de modo análogo ao funcinamento do mercado econômico. Logo, Downs (1999) caracteriza os partidos no momento eleitoral como produtos oferecidos aos eleitores, que escolheriam àqueles mais adequados aos seus gostos, como consumidores. "A função política das eleições numa democracia (...) é selecionar um governo. Portanto, comportamento racional vinculado às eleições é comportamento orientado para esse fim e nenhum outro" 
(Downs, 1999: 29). Os partidos e os políticos desejam cargos, e formulam políticas para receber os votos dos cidadãos. As políticas e as plataformas eleitorais são os diferenciais que cada partido procuraria mostrar aos "consumidores-cidadãos", que tomariam a decisão sobre que comportamento tomar (comparecer à votação e decidir a direção do voto) com base em cálculos de eficiência.

Ao incluir a incerteza e a informação incompleta no modelo teórico, Downs deve explicar como os eleitores obtêm e processam as informações necessárias para a tomada de decisão. Ou seja, visto que os cidadãos não têm total conhecimento sobre as propostas dos políticos/partidos, nem domínio sobre o resultado futuro de suas ações, a teoria deve postular um mecanismo que possibilite ao eleitor, racionalmente, a tomada de direção do voto. Nesse ponto aparece a ideologia e a Identificação Partidária. Nas palavras do autor, "a incerteza permite que os partidos desenvolvam ideologias como armas na disputa do poder" (Downs, 1999: 117). Assim, ela aparece como um instrumento de diferenciação entre os partidos: "Muitos eleitores descobrem que as ideologias partidárias são úteis porque eliminam a necessidade de que eles relacionem cada questão a suas próprias filosofias" (Idem: 119). O mesmo processo ocorre com a IP.

A causa comumente atribuída pela rational choice à IP é diversa, portanto, da escola de Michigan. Ao invés do postulado de sua formação no processo de socialização, imputado no indivíduo de forma razoavelmente estável ao longo do tempo, Downs concebe a IP como um atalho de informação usado pelo eleitor racional. Após uma série temporal de eleições vivenciadas, de informações apreendidas, o eleitor começa a perceber que alguns partidos estão sistematicamente mais próximos de sua preferência do que outros. Logo, poupa-se de maiores esforços futuros e passa a "confiar" no partido escolhido.

Assim, pode-se dizer que um contexto político no qual os partidos mantêm suas plataformas mais ou menos estáveis durante longo período de tempo, a volatilidade eleitoral seria pequena, visto que os eleitores não teriam incentivos para mudar sua identificação e preferência partidária já racionalmente formatada. À diferença do modelo da psico-sociologia, no entanto, aqui a ligação estável entre partidos e eleitores não se estrutura a revelia do comportamento político dos partidos. 
Uma das vertentes da escolha racional apresenta visão diversa sobre a motivação da manutenção ou mudança da direção do voto. O conhecido modelo do voto econômico considera que uma variável chave para determinar a direção do voto é o desempenho econômico do governo. Figueiredo (1991: 67) assim resume o argumento "se a economia vai bem, os governantes ganham mais votos; se, contrariamente, a economia vai mal, a oposição se beneficia”. A relação entre partidos e eleitores é, dentro dessa perspectiva, tênue: os segundos pouco utilizariam dos atalhos fornecidos pelas imagens dos primeiros, antes decidiriam seu voto com base no seu "bolso", ou no "bolso" de todos. Assim, não existe indicações a priori, para essa teoria, de que a volatilidade deveria ser alta ou baixa, até porque, mesmo uma situação na qual o governo é bem avaliado, o crescimento na votação do partido em exercício impacta na volatilidade da mesma forma que a punição eleitoral de um governo de péssimo desempenho econômico.

Kramer (1971: 140-1), ao estudar a variação na votação dos partidos para Câmara dos Deputados nos EUA, conclui que "economic fluctuations, in particular, are important influences on congressional elections, with economic upturn helping the congressional candidates of the incumbent party, and economic decline benefitting the opposition”. Na literatura nacional, Carreirão (2002) se destaca como defensor dessa tese. Analisando o comportamento eleitoral nas eleições presidenciais brasileiras de 1989, 94 e 98, uma das conclusões de Carreirão (2002: 208) é "os dados analisados parecem suficientes para indicar que o 'voto econômico' (...) foi uma das motivações centrais do eleitor nas três eleições presidenciais brasileiras recentes". Mais recentemente, Rennó e Spanakos (2006: 33), afirmam que “intenções de voto no Brasil são influenciadas pela economia seguindo um padrão previsto pela teoria do voto retrospectivo".

O padrão geográfico dos votos no PT no pleito presidencial de 2006 também foi interpretado pela vertente do voto econômico: o programa de transferência de renda Bolsa-Família, o aumento expressivo do salário mínimo e outras iniciativas governamentais teriam sido as causas, segundo alguns autores, para a forte penetração do PT em municípios pobres do Nordeste, por exemplo. (Ver, dentre outros, Nicolau e Peixoto, 2007) 
Algumas vertentes da escolha racional não eliminam variáveis sociológicas de suas explicações, apenas a minimizam. Na questão da identificação partidária, por exemplo, Fiorina (1981) afirma que de fato, em algumas situações, o processo de socialização pode gerar IP sem prévio conhecimento da política, mas essa identificação estaria subordinada ao controle contínuo das políticas partidárias. Como sintetizam Carreirão e Kinzo (2004: 133) "se a socialização do indivíduo previamente à sua vida adulta tem um peso na identificação partidária, peso ainda maior tem a avaliação que o indivíduo faz da experiência acumulada como eleitor ao longo de sua vida adulta". Huckfeldt e Sprague (1995) defendem análise contextual do comportamento político, conjugando abordagens da escola sociológica com a da escolha racional, ressaltando processos de comunicação, troca de informação, redes e vizinhança na conformação das preferências políticas, mantendo supostos de individualismo metodológico e racionalidade instrumental.

Przeworski (1989) levanta outra hipótese, que inspira esta pesquisa. Ao discutir as estratégias eleitorais dos partidos de esquerda europeus no começo do século XX, o autor discute a mobilização do eleitorado operário e a correspondência entre partido e classe social. A questão é: qual é o impacto de plataformas eleitorais que contemplavam reivindicações de outras classes sobre o sucesso eleitoral dos partidos e sobre a composição de sua base operária? O dilema está na existência de um suposto trad-off entre apelos à classe média e votação entre os trabalhadores: quanto mais os partidos esquerdistas utilizassem da primeira estratégia, mais perderiam eleitores da classe trabalhadora. O autor propõe, logo, uma conjugação das abordagens sociológicas e racionais.

Mantendo-se coerente com a linha de argumentação do paradigma, o fenômeno da volatilidade eleitoral é visto menos como ausência de alguma qualidade por parte do eleitor que de uma mudança de curso estimulada por cálculos racionais. Para Figueiredo (1991:93) “a flutuação na direção do voto é função da capacidade dos partidos em suprir os diversos segmentos sociais com políticas que atendam primeiramente às demandas de curto prazo e, secundariamente, os projetos políticos de longo prazo". Como a IP não é fruto de imposições psicológicas nem de grupos sociais, mas sim de cálculos racionais de informação, o eleitor não se mantém fiel a partidos a menos que suas preferências sobre políticas públicas sejam, ao menos parcialmente, atendidas. 
Logo, a escolha racional ressalta dois mecanismos diferentes para explicar a manutenção/mudança do voto: de um lado, o modelo espacial clássico derivado de Downs implica, no longo prazo, certa estabilidade eleitoral, dado a distribuição mais ou menos constante dos partidos e eleitores num contínuo ideológico; de outro lado, no modelo econômico, a estabilidade é fruto da avaliação que o eleitor faz do desempenho e dos atos do governo, principalmente de seus impactos econômicos.

\section{Síntese}

Esta seção sobre comportamento eleitoral visa ressaltar as bases teóricas que fundamentam as premissas sobre o comportamento do eleitor subjacentes às teorias sobre a volatilidade. As discussões advindas do debate que chamei de matriz européia estão calcadas na sociologia e psico-sociologia eleitoral. As expectativas criadas para o caso brasileiro não eram otimistas: aqui, a ausência de estruturas partidárias assentadas em clivagens sociais e de níveis elevados de identificação partidária implicariam em alta volatilidade e inconsistência do resultado eleitoral.

No entanto, alguns aspectos da escolha racional podem trazer elementos interessantes para se compreender o caso brasileiro. Como notam Carmines e Huckfeldt (1998), algumas assunções trazidas pela rational choice impactaram a sociologia e a psicologia política, fazendo com que estas tivessem que repensar seus paradigmas.. Defenderei que a dinâmica da competição eleitoral pode levar a uma estruturação da posição dos partidos e eleitores num contínuo ideológico, perfazendo um cenário de considerável estabilidade eleitoral. Ademais, muito da flutuação pode ser atribuída a mudanças na oferta de candidaturas, e tende a ser entre partidos contíguos no espaço político. Ou seja, o comportamento dos eleitores é um produto da interação entre estratégias das elites e suas preferências, sendo que estas últimas não são independentes da ação das primeiras.

\section{O debate americano sobre competição eleitoral}

A visão da escolha racional sobre o comportamento eleitoral influenciou a produção de estudos que tocam na questão da volatilidade ou do eleitor flutuante em registro teórico diverso do debate tradicional apresentado no capítulo anterior. Trata-se da literatura sobre competição eleitoral, política distributiva, uma discussão 
eminentemente norte-americana, na qual o comportamento do eleitor é tematizado como sendo swing (volátil) ou core (partidário), e a discussão gira em torno das estratégias de ligação entre partidos e cidadãos. Aqui, focaremos especificamente na contribuição de Gary Cox.

De modo geral, as literaturas sobre volatilidade eleitoral européia e a norteamericana sobre swing voter não se comunicam. De um lado, as questões teóricas gerais subjacentes são diversas: na primeira temos a preocupação com o papel dos partidos na democracia nas condições contemporâneas, a questão da representação e da identificação entre partidos e eleitores; na segunda, trata-se de estudar, teorica e empiricamente, como partidos e eleitores se comportam estrategicamente dado as regras eleitorais e a estrutura da competição.

Proponho um diálogo entre essas discussões. Acredito que uma ponte entre as perspectivas pode trazer ganhos analíticos. De fato, em ambos os debates as referências às preocupações do "outro lado" estão presentes. Cox, por exemplo, ao discutir as estratégias ótimas dos partidos para maximizar votos, - focar-se nos seus eleitores partidários ou nos eleitores flutuantes, afirma que esse problema é importante também porque toca na questão da representação política: como se forma o link entre partidos e eleitores e a quem os partidos buscam representar? (Cox, 2010: 343). Outro exemplo é dado por Cox e Amorim Neto (1997), que defendem que um modelo adequado para a compreensão do quadro partidário deve integrar variáveis da literatura sobre clivagem com elementos advindos de argumentos institucionalistas. Lane e Ersson (1997) e Bartolini e Mair (1990), assentados na tradição européia, afirmam a necessidade de se considerar os aspectos instrumentais envolvidos na dinâmica eleitoral, e não apenas dimensões expressivas. Esses são apenas exemplos de que como, a despeito de estarem assentadas em arcabouços e pressupostos teóricos dessemelhantes, as duas perspectivas, creio, são passíveis de comunicação recíproca.

No livro Making Votes Count, Cox discute a relação entre partidos e eleitores do ponto de vista de um jogo de coordenação. Como se sabe, em teoria dos jogos, o jogo de coordenação ocorre quando os atores ganham quando cooperam, mas cada um tem preferências diversas sobre qual das alternativas "cooperativas" seguir. O clássico exemplo didático levantado é o do casal que deseja se encontrar, mas deve escolher entre boxe, opção preferida do homem, e espetáculo de dança, alternativa desejada pela 
mulher. O dilema está em se coordenar para tomar uma decisão e evitar o pior resultado, qual seja, não se encontrar. Há conflito de interesse entre as duas alternativas "cooperativas".

No que diz respeito ao jogo eleitoral, existem dois dilemas de coordenação, intra-elites políticas e destas com os eleitores. Os políticos são office-seeking, mas, ao mesmo tempo, têm preferências por políticas; os eleitores têm identificações partidárias, mas principalmente interesses por políticas públicas. Logo, dependendo da situação institucional (sistema partidário e eleitoral) ambos os atores têm leques de estratégias diversas a adotar. Os partidos podem adotar estratégias que, a despeito de trazer vantagens pessoais, podem levar à eleição de adversários ideológicos; eleitores podem votar nos seus partidos preferidos, mas assim contribuir para a vitória de concorrentes menos desejados. Numa situação como a brasileira, com multipartidarismo, estrutura federativa de poder e diferentes regras eleitorais presidindo os pleitos, esse jogo de coordenação se complexifica sobremaneira.

O interessante de uma proposta desse tipo, para a presente discussão, é introduzir um caráter estratégico para o momento eleitoral. Mesmo considerando que existem elementos ideológicos presentes, seja pelo conceito de clivagens (como na literatura clássica de volatilidade) seja por posições espaciais (como na literatura de inspiração downseana), a disputa eleitoral abarca comportamentos estratégicos dos eleitores e dos partidos.

Com isso podemos trazer outros subsídios para se pensar a volatilidade eleitoral e o debate sobre o tema no Brasil. As discussões sobre a institucionalização do quadro partidário, sobre a força das legendas no momento eleitoral e sobre os laços entre cidadãos e partidos podem ganhar novos patamares ao incorporar elementos do registro teórico que estamos aqui discutindo. Uma das questões pode ser: qual deve ser o objeto empírico do estudo sobre volatilidade: as eleições para o legislativo ou para o executivo? Qual o papel do lançamento de candidaturas para se compreender a volatilidade?

Retornando para a exposição de alguns pontos da teoria de Cox, o autor estabeleceu três tipos de ações estratégias empreendidas pelos atores no momento eleitoral: coordenação, mobilização e persuasão (Cox, 2005). A primeira, discutida acima, se subdivide em dois tópicos: coordenação entre as elites políticas e entre os 
eleitores. A primeira diz respeito à entrada no jogo eleitoral, ou seja, ao lançamento de candidatura. Os partidos enfrentam o dilema de, ao lançarem plataformas semelhantes, dividirem o eleitorado e, dependendo do sistema eleitoral, favorecer candidatos adversários. Ao mesmo tempo, cada um dos partidos prefere, obviamente, ser o "ponto focal" do equilíbrio: daí o dilema da coordenação. Os eleitores enfrentam estrutura semelhante: cada um, individualmente, deve pautar seu comportamento tendo em vista o dos demais, de modo a não "desperdiçar seu voto".

A mobilização eleitoral diz respeito à atividade partidária de convencer seus eleitores a comparecerem à votação e a manterem seu voto sincero. A persuasão, por fim, é a atividade de mudar as preferências dos eleitores: os partidos buscam aumentar suas fileiras incorporando eleitores neutros ou os partidários dos adversários.

Assim, o conjunto do eleitorado (num sistema bipartidário) é dividido como se segue: eleitores partidários de $\mathrm{A}$, partidários de $\mathrm{B}$ e neutros. O jogo eleitoral se dá em torno dessa situação. Os eleitores neutros, por definição, são swing voters, ou seja, voláteis. Mudam a direção de seu voto em cada eleição. Uma das discussões que mobilizou a literatura diz respeito a qual deve ser a estratégia ótima adotada por partidos desejosos de ganharem a eleição: investimento no grupo de eleitores partidários, nos core voters, ou nos voláteis, nos swing voters?

Dentre outros, Stokes (2005) defende a segunda estratégia. Sua discussão tem como interesse substantivo o jogo eleitoral em novas democracias que possuem máquinas partidárias. O modelo formal da autora busca mostrar que o partido "clientelista" deve, no momento eleitoral, concentrar sua estratégia na persuasão de eleitores não identificados com ele. No caso, mantida a premissa da rational choice, persuasão nada mais é que compra de voto. O partido deveria assim proceder porque, segunda a autora, as ameaças de defecção (não votar no partido) por parte dos identificados, caso não sejam o alvo do "suborno", não é crível: por serem ideologicamente identificados com o partido, seu comportamento eleitoral não é pautado por benefícios de curto prazo por ele oferecidos. Assim, os partidos não deveriam desperdiçar recursos com seus core voters.

Cox (2010) defende a opção oposta. Seu argumento é de que os modelos de estratégia eleitoral estão focados apenas na ação de persuasão, e não levam em conta a coordenação e a mobilização eleitoral. A estratégica destinada ao core voter seria mais 
importante porque de um lado impede ou minimiza que partidos do mesmo espectro ideológico lancem candidatos, por meio da diminuição de apoio eleitoral esperado que estes partidos teriam, ou impede, tendo eles entrado na disputa, que sejam bem sufragados. No que diz respeito à mobilização, Cox chama atenção para o fato de que os partidos devem convencer os eleitores a participarem da votação, e, ainda que isto seja mais premente em países de voto não-obrigatório, também está presente quando o custo de votar não é homogeneamente distribuído pela população. No modelo do autor, a mudança de preferência, persuasão, é tida como secundária. Isto se deve, em parte, ao fato de ser um modelo estático, buscando entender os parâmetros de uma única eleição. De outro lado, essa opção também diz respeito ao paradigma da escolha racional: as preferências são tratadas como exógenas. Os modelos não discutem como elas são formadas, ou sua evolução no tempo.

Idema (2009) apresenta um outro ponto importante, propondo uma nova visão sobre os swing voters. Seu argumento é de que a volatilidade dos eleitores é espacialmente circunscrita entre sub-conjuntos de partidos. A analogia com o mercado econômico é utilizada pelo autor: os consumidores, mesmo quando não possuem preferências firmes sobre uma marca, realizam uma espécie de primeiro filtro: descartam os produtos que não comprariam, para depois escolher um dentre os restantes. Com os eleitores, o raciocínio é semelhante.

A não identificação com nenhum partido não implica em possibilidade de voto em qualquer um dos postulantes. Existiriam distinções que afastariam os eleitores de determinados partidos, e os predisporiam a votar em outros. O espaço no qual os eleitores se movimentam é restritivo ${ }^{36}$. Assim, cada eleitor volátil não estaria, necessariamente, disponível para todos os partidos. Acredito que essa visão pode ser útil para se pensar o caso brasileiro, constituído por multipartidarismo e por índices de identificação partidária não elevados ${ }^{37}$. Diante de muitas opções para votar, o eleitor brasileiro que não tem uma preferência eleitoral clara não se comportaria, necessariamente, de maneira instável, sem nenhum padrão. Antes, pode-se levantar a

\footnotetext{
${ }^{36}$ Esse argumento faz um contraponto importante à idéia de que a identificação partidária (com apenas uma legenda), tal como mensurada em um survey, pode ser tomada como principal proxy de estabilidade eleitoral.

${ }^{37}$ Ver, dentre outros, Veiga (2007).
} 
hipótese que o eleitor possui preferência por determinados blocos ideológicos, que conformariam a decisão de seu voto no longo prazo.

Por certo, as discussões sobre volatilidade, na sua forma padrão, não partem dessas discussões. Naquelas, as preferências são frutos de clivagens sociais e políticas e se refletem em partidos a elas ancorados. Do ponto de vista da literatura sobre comportamento eleitoral, os paradigmas sociológicos e psico-sociológicos são os mais apropriados para essa visão. A volatilidade seria fruto da dissolução desses laços, e conseqüentemente, da ausência de identidades mais estáveis por parte do eleitorado. A despeito dessa diferença, acredito que aqui também existe um ponto de encontro entre as discussões sobre swing e core voter e sobre volatilidade eleitoral. Isso porque nos modelos do primeiro grupo, quais seriam os eleitores partidários? No texto de Stokes fica explícito que esses são os identificados com os partidos, e que essa relação não tem nada ou quase nada a ver com os benefícios de curto prazo. Em Cox podemos encontrar elementos para uma consideração importante. Ao defender a hipótese de que a ação ótima dos partidos é fazer promessas e destinar benefícios aos seus eleitores identificados, podemos considerar que isso contribui também para manter esse grupo de apoio. Em outras palavras, as ligações identitárias, sociológicas e psicológicas do eleitor com os partidos podem não ser condição suficiente para a manutenção dessa relação no tempo, ou, em outras palavras, para baixos índices de volatilidade; o retorno concedido pelos partidos, por meio de políticas, leis, performance governamental, etc. pode ser também condição necessária para tal.

Essa é a perspectiva adotada por Diaz-Cayeros, Estévez e Mangaloni (2007). Uma pergunta que guia os autores é: se os eleitores core são reiteradamente ignorados por promessas e benefícios ofertados pelos seus partidos, por que deveriam manter sua preferência partidária? Os autores então defendem que a identificação partidária é condicional ao comportamento dos políticos, às plataformas e promessas realizadas, e às políticas públicas executadas.

Assim, a ligação eleitor-partido no tempo, das preferências políticas, pode ser analisada dentro da escolha racional por meio da ação dos partidos visando "criar" seu eleitorado, dentro, obviamente, de determinados parâmetros. Essa perspectiva foi aventada por Przeworski, como apresentado na seção anterior. 
$\mathrm{O}$ autor conjuga arcabouços da sociologia e da questão das clivagens sociais com elementos racionais e estratégicos. Ao discutir os diferentes pesos que classe social assume na determinação do comportamento eleitoral, em diferentes contextos europeus, o autor defende a tese de que as clivagens e as linhas divisórias da competição eleitoral são ditadas pela ação dos partidos políticos. Logo, mesmo que a situação de classe seja uma condição objetiva, Przeworski afirma que para ela se tornar um conflito políticoeleitoral é necessária a mediação dos partidos políticos, que mobilizam diferentes estratégias para conquistar apoio dos eleitores (outras dimensões objetivas que também podem ser politizadas são etnia, religião, raça). Essas estratégias, no entanto, são limitadas pelas condições objetivas e subjetivas vividas pelos cidadãos. Poderíamos dizer que o movimento de Przeworski é, em parte, inspirado pelas intuições de Schumpeter (1984), que afirmara, invertendo o vetor da soberania popular, que não são os cidadãos que escolheriam os políticos, mas os políticos que escolheriam os cidadãos. Essa inspiração é conjugada a supostos sociológicos ou marxistas do conflito social.

A persuasão do modelo de Cox pode então ser vista como estratégia partidária para formar seu eleitorado, por meio da transferência de benefícios. Cox, em determinado momento, afirma que:

"in general, parties can persuade by repositioning themselves along the left-right spectrum, by convincing voters that they are more competent at providing Valence goods, by slinging mud at their opponents, and so forth. In the models under consideration here, the method of persuasion is offering transfers." (Cox, 2010: 348).

Os core voters de hoje são os persuadidos de ontem. Essa perspectiva dinâmica também ressoa na crítica de Przeworski (1989: 146) a Downs, quando aquele afirma que "as estratégias escolhidas pelos líderes partidários hoje produzem condições sob as quais terão de tomar decisão na eleição seguinte. A inadequação da teoria de Downs sobre a competição partidária deve-se à hipótese de que os partidos deparam com um público exógeno. Ao examinarmos as estratégias partidárias sob uma perspectiva histórica, como um processo, não podemos considerar cada eleição como um evento sem antecedentes e sem conseqüências posteriores".

\section{Síntese}

Vimos, nesta seção, um conjunto de textos que trata do eleitor flutuante em registro diverso da literatura tradicional de volatilidade. Uma das propostas desta 
pesquisa é levantar os ganhos heurísticos que um diálogo com os pressupostos da literatura sobre competição eleitoral, de inspiração da escolha racional, pode trazer para o debate sobre volatilidade eleitoral, notadamente por meio da noção de coordenação intra-elites e coordenação dos eleitores, e por meio das estratégias de persuasão e mobilização de core voter ou swing voter. Logo, quero ressaltar que o uso que pretendo fazer aqui tem ênfase substantiva e empírica diversa desta perspectiva "americana": não se trata de buscar modelos formais, mas antes discutir a institucionalização do sistema partidário brasileiro. Foge à minha capacidade oferecer uma teoria completa. Apenas pretendo ressaltar que as decisões sobre lançamento de candidaturas e a "construção" (ou persuasão) de eleitores, principalmente quando os partidos estão no governo, são as principais variáveis que apresento para a compreensão da volatilidade eleitoral. 


\section{Capítulo III - Pressupostos teóricos e procedimentos metodológicos adotados}

Após a discussão bibliográfica e teórica sobre volatilidade e competição eleitoral, busco apresentar aqui os procedimentos teórico-normativos e metodológicos que guiarão a análise empírica no próximo capítulo. Na primeira seção deste capítulo, apresento uma rápida discussão sobre a relação entre a volatilidade e a teoria democrática, depois apresentarei discussões metodológicas sobre o índice de volatilidade de Pedersen; em seguida proporei os cargos majoritários como unidade de análise; na seção seguinte apresentarei a hipótese e de que forma ela será trabalhada, para então apresentar a estrutura dos dados a serem analisados.

\section{Democracia e competição eleitoral}

A democracia política é o regime baseado, essencialmente, em eleições competitivas e periódicas para a escolha dos dirigentes políticos. Essa definição, de matriz schumpeteriana, acrescida à dimensão da inclusão de Dahl (1997), que diz respeito ao nível de abrangência dos direitos políticos na população, constitui o ponto de partida central da teoria democrática.

Mas, o que são "eleições competitivas"? O que significa dizer que a relação entre os diferentes partidos e os diferentes cidadãos, no momento eleitoral, é de característica competitiva? Essas questões são cruciais para um entendimento teórico normativo e positivo - do objeto deste trabalho.

A base normativa dos estudos de volatilidade está ancorada na seguinte linha de raciocínio: uma democracia institucionalizada exige um nível elevado de estabilidade na direção do voto do eleitor. Partidos devem contar com bases eleitorais razoavelmente estáveis. Para além do significado preciso dos adjetivos "elevado" e" razoavelmente", o que cabe aqui destacar é que o foco se volta para a estabilidade do vínculo entre partido e eleitor.

A discussão sobre teoria democrática de Bartolini (1999) pode nos ajudar a trazer outros elementos. Para o ponto que nos interessa neste trabalho, o autor coloca o dilema teórico crucial: a competição eleitoral democrática exige algum nível considerável de "disponibilidade" de eleitores e de abertura na "entrada" partidária. Vejamos. 
Imagine-se um cenário onde exista completa estabilidade na direção partidária do voto. Todos os votantes se identificam com algum partido, e estes têm profundas raízes na sociedade. Em conseqüência, o resultado eleitoral sempre é conhecido de antemão. Pode-se dizer que tal situação perfaz um contexto democrático?

Acredito que nenhum analista responderia afirmativamente. Como afirma Bartolini, uma condição necessária para accountability e responsiveness dos eleitos para como os cidadãos é que "voters are willing to punish and reward; that is, they are available to modify their electoral choice" (p. 454). A ausência de potencialidade de volatilidade, em outros termos, prejudica a competição democrática.

Ademais, o autor também endereça a importância da "contestability" e “decidability" da oferta partidária. O leque de opções de escolha do eleitorado não deve ser estritamente fechado (as barreiras à entrada não podem ser elevadas) e os partidos devem se diferenciar entre si, ou seja, elaborar plataformas políticas divergentes.

Trago esses elementos de caráter normativo para explicitar dimensões teóricas subjacentes ao debate de volatilidade. Mudanças na direção do voto e no quadro de competidores não são fenômenos alheios a uma democracia institucionalizada. Antes o contrário: fazem parte do seu cerne.

A hipótese empírica defendida aqui é que a magnitude do índice de volatilidade eleitoral do Estado de São Paulo, mesmo quando exibindo números elevados, expressa na verdade uma relativa estabilidade eleitoral. Esse quadro se mostra quando se observa que grande parte da volatilidade é causada por mudanças na oferta partidária, na “contestability", na expressão de Bartolini. Estratégias eleitorais dos partidos modificam o leque de opções do eleitor, perfazendo resultados eleitorais aparentemente instáveis, segundo minha hipótese.

Poder-se-ia argumentar que mudanças na oferta partidária são expressões de um sistema partidário não institucionalizado. Num cenário ideal, os agrupamentos partidários seriam constantes na apresentação de plataformas. O caso brasileiro seria, assim, um exemplo de fluidez partidária. 
Contudo, não se deve perder de vista o cenário inverso, Mair (2009), por exemplo, discute as implicações de um sistema partidário cartelizado ${ }^{38}$ para o funcionamento do sistema representativo como um todo. O que nos interessa aqui é a passagem na qual o autor afirma que os sistemas europeus multipartidários estariam passando por processos por ele denominados de "bipolarismo": "by bipolarism I refer here to the tendency for parties in multiparty systems to group together to offer alternative governments and pre-electoral coalitions, thus given voters the opportunity to choose between alternative teams of leaders even within the context of fragmented multiparty politics" (Mair, 2009: 8).

O ponto avaliativo feito pelo autor é o de que as vantagens normativas advindas de um sistema "consociativo", a saber, maior inclusão de diferentes demandas, estariam sendo minimizadas pelo "conluio" efetuado pelos partidos cartelizados.

O comentário de Mair aponta para uma característica positiva da dinâmica da competição partidária no Brasil: a bipolarização entre PT e PSDB, que organiza o quadro partidário nacionalmente, não ocorre sem a presença constante de plataformas alternativas, nos diferentes níveis e cargos de competição.

O ponto a ser destacado é o de que a volatilidade eleitoral causada pela mudança nas ofertas de candidaturas, que defendo impactarem fortemente a volatilidade eleitoral, podem ser vistas como desejáveis para o funcionamento do sistema representativo ${ }^{39}$.

Entretanto, a despeito dessas considerações, penso que a estrutura institucional brasileira não está isenta de acarretar dificuldades para a institucionalização partidária brasileira. A estrutura federativa e os diferentes padrões de inserção partidária implicam, muitas vezes, em coligações eleitorais heterogêneas: partidos podem ser aliados em alguns distritos, mas adversários em outros. Ademais, a "divisão do trabalho

\footnotetext{
${ }^{38}$ Essa expressão faz referência à tipologia atual dos partidos defendida por Katz e Mair (1995, 2009), apresentada no primeiro capítulo.

39 No campo da teoria democrática, Manin (1987) defende que o embate entre partidos e candidatos constitui uma das bases da legitimidade democrática, possibilitando a formulação e reformulação de preferências e vontades políticas. Em outras palavras, a possibilidade de "novos" partidos competitivos disputarem os cargos tende a forçar cada legenda "constante" a formular e reformular plataformas políticas próprias.
} 
partidário-eleitoral" entre cargos majoritários e proporcionais pode implicar em legislativos com alta fragmentação partidária, interferindo na formação de coalizões governamentais e impactando na capacidade do eleitor de julgar o desempenho do governo.

Esses fatores incentivam a produção de novos estudos voltados para essa temática. Concordo com Nicolau (2010: 235) quando este afirma que "não podemos abandonar as boas questões que mobilizaram os pesquisadores ao longo destes anos (...). Afinal, o que podemos dizer sobre o processo de institucionalização dos partidos no Brasil?”. Este estudo pretende se inserir nesta questão maior, procurando trazer novos subsídios empíricos e teóricos. Por certo, conclusões e inferências que se podem fazer para os outros distritos brasileiros são desafios empíricos a ser realizados.

\section{Índice de volatilidade de Pedersen}

A discussão da volatilidade e da flutuação eleitoral, como vimos, utiliza empiricamente o indicador formulado por Pedersen. Sua fórmula é:

$$
\mathrm{VT}=\Sigma \mid(\text { Pit2 }- \text { Pit1 }) \mid / 2
$$

Onde VT: Volatilidade total; Pit2: porcentagem de votos do partido i em t2 e Pit1: porcentagem de votos do partido i no t1. O algoritmo consiste na mudança líquida da força eleitoral dos partidos em dois pontos do tempo. É líquida porque duas mudanças em sentidos opostos, por exemplo, de um eleitor do partido A para o B, e de outro, do B para o A, se cancelam. Logo, segue que o resultado do índice de volatilidade é o limite mínimo das mudanças das preferências partidárias expressas em dois momentos no tempo.

Pensando numa situação hipotética: na eleição inicial T1, o partido A consegue $40 \%$ dos votos, o partido B $30 \%$ e o C também 30\%. No pleito seguinte, T2, metade dos eleitores do partido A, que perfazem $20 \%$ do total de eleitores, flutuam em direção ao partido $\mathrm{B} ; 33 \%$ dos votantes de $\mathrm{B}$, ou $10 \%$ do total, mudam para $\mathrm{C}$; o mesmo se dando de C em direção ao partido A. O cenário final, em T2, fica: A: 30\%, B: $40 \%$ e C: $30 \%$. Os quadros 1 e 2, abaixo, resumem ambos cenários. O índice de volatilidade, por ser uma medida mínima de flutuação, resultaria em 10\% de volatilidade, quando na verdade, como mostra o quadro $3,40 \%$ do total de eleitores mudaram de voto entre T1 e 
T2 (ver os valores marcados em negrito). Isso se deve ao fato do cancelamento de mudanças recíprocas de voto na direção contrária.

\begin{tabular}{cc}
\multicolumn{2}{c}{ Quadro 1 - Eleição em T1 } \\
\hline \hline Partidos & Votos \\
\hline A & 40 \\
B & 30 \\
C & 30 \\
\hline \hline
\end{tabular}

Fonte: Elaboração Própria

\begin{tabular}{cc}
\multicolumn{2}{c}{ Quadro 2 - Eleição em T2 } \\
\hline \hline Partidos & Votos \\
\hline A & 30 \\
B & 40 \\
C & 30 \\
\hline \hline
\end{tabular}

Fonte: Elaboração Própria

Quadro 3 - Flutuação real do voto

\begin{tabular}{lcclr}
\hline \hline T1/T2 & A & B & C & Total \\
\hline A & 20 & $\mathbf{2 0}$ & - & 40 \\
B & - & 20 & $\mathbf{1 0}$ & 30 \\
C & $\mathbf{1 0}$ & - & 20 & 30 \\
Total & 30 & 40 & 30 & 100 \\
\hline \hline
\end{tabular}

Fonte: Elaboração Própria

Outro problema presente no índice é que, em geral, o cálculo não leva em consideração a variação do comparecimento eleitoral. Os eleitores que votam em uma eleição não são os mesmos que participam da seguinte. Os motivos para isso são vários: novos eleitores se alistam, alguns se abstêm no primeiro pleito, outros no segundo, eleitores mudam de distrito ou morrem, etc. Ademais, nos estudos sobre volatilidade, muitas vezes não há referências ou justificação quanto ao tratamento a ser dado aos votos em branco ou anulados.

Essas propriedades metodológicas do índice de volatilidade foram notadas pela literatura. Todas estão relacionadas com a questão da inferência e da falácia ecológica. Trata-se de fazer considerações sobre o comportamento individual a partir de dados agregados. Tendo em vista a teoria que embasa a questão da volatilidade, pode-se questionar se a agregação dos dados consiste realmente num problema. Afinal, aqui, pode-se argumentar, o interesse consiste em averiguar a força, a estabilidade e a consistência dos partidos no momento eleitoral no que diz respeito a frações do eleitorado, e não a cada eleitor individualmente. Lipset e Rokkan, por exemplo, não estariam interessados no fenômeno tomado agregadamente, ao discutir clivagens e sistema partidário?

Lane e Ersson (1997) discutem essa questão detidamente. Diferenciam a estabilidade "superficial" (surface stability), medida pela volatilidade líquida 
(Pedersen), da estabilidade estrutural, mensurada de forma desagregada, no nível individual. Afirmam que existe uma tensão na relação entre o nível micro (o eleitor) e o macro (o sistema partidário) na discussão que caminha a partir do estudo de Lipset e Rokkan. A clivagem, para os autores, é o que conecta o primeiro ao segundo, de forma estável ou instável. Ao analisar dados de survey sobre mudança partidária, e dados elaborados pelo índice de volatilidade de Pedersen, em alguns países europeus no pósGuerra até os anos 90, os autores mostram que a medida agregada representa, na média, cerca de $50 \%$ da instabilidade estrutural, capturada por meio de entrevistas individuais. Logo, podemos concluir, o índice de volatilidade apresenta um valor consideravelmente distante das mudanças eleitorais realmente ocorridas.

Bartolini e Mair (1990) apresentam conclusão diferente. Primeiramente, afirmam que mesmo o índice agregado de volatilidade eleitoral abarca duas interpretações diferentes: de um lado, pode ser visto como uma propriedade sistêmica, de outro, como um indicador de mudanças individuais acumuladas. Os autores ressaltam, portanto, que o mesmo procedimento metodológico é passível de visões diferenciadas, dada a referência conceitual utilizada. (Bartolini e Mair, 1990: 24-5). Assim, do primeiro ponto de vista, as complicações concernentes à inferência ecológica não estariam presentes, dada a ênfase da discussão posta sobre o sistema partidário, seu formato e sobre o comportamento estratégico dos partidos. De outro lado, nas visões sobre o comportamento dos eleitores, o "espectro" da falácia ecológica está presente. Entretanto, diferentemente de Lane e Larsson, os autores, utilizando-se tanto de dados de survey, quanto de raciocínios lógicos provenientes da teoria da probabilidade, defendem que o índice de volatilidade de Pedersen representa uma aproximação razoável da flutuação individual (Idem: 34).

Tais ponderações pedem algumas considerações. Primeiramente, conforme destacado por Lane e Ersson (1997: 184) os resultados de pesquisas sobre mudança eleitoral individual auferidos por entrevistas são, muitas vezes, consideravelmente divergentes entre si. Por exemplo, é conhecido o efeito "bandwagon": em pesquisas pós-eleitorais, os partidos vencedores tendem a receber mais declarações do que votos efetivamente obtidos na eleição. $\mathrm{O}$ indicador possibilitado pelo comportamento expresso nas urnas, deste ponto de vista, é confiável. Segundo, o olhar sobre o índice, bem como sobre qualquer tipo de dado, depende do debate teórico que se deseja realizar. Estudos que se voltam para as discussões sobre volatilidade e 
institucionalização do sistema partidário, no Brasil como alhures, devem respeitar os diversos níveis e dimensões de análise que a medida comporta. Assim, avaliações sobre o comportamento de eleitores, sejam tomados individualmente, sejam agrupados, por meio de clivagens, e sobre a força dos partidos, sejam unitariamente, sejam ajuntados em blocos ideológicos ou em outras divisões, são realizadas sem muitas vezes as devidas pormenorizações. A alta volatilidade do caso brasileiro, por exemplo, como defendida por grande parte da literatura, significa que nosso sistema partidário é incipiente e fluído? Ou que os eleitores não apresentam laços ou compromissos com partidos individuais? Qual é o papel das clivagens nessa ligação entre o micro e o macro? E das estratégias eleitorais dos partidos?

Defendo, nesta pesquisa, que o índice de volatilidade eleitoral não pode ser devidamente utilizado sem considerações de natureza teórico-conceitual sobre o seu significado para os debates que estamos mobilizando. Lane e Ersson, por exemplo, advertem para a necessidade de se formular um modelo teórico que congregue tanto as assunções da perspectiva mais sociológica de Lipset e Rokkan quanto as advindas de uma visão centrada em "tactics and strategy of electoral campaigning" (Lane e Ersson, 1997: 190). Assim, as lealdades dos eleitores a partidos, e o caráter expressivo das clivagens sociais, não devem ser tomados como únicos fatores para se compreender a volatilidade eleitoral. O comportamento estratégico, tanto das elites quanto dos eleitores, também deve ser levado em conta.

Bakke e Sitter (2005) defendem argumento semelhante, ao estudar o sistema partidário na Hungria, Polônia, República Checa e Eslováquia, buscando entender as diferenças entre os níveis de estabilidade do sistema partidário entre esses países do Leste Europeu. A tese dos autores é a de que as estratégias partidárias dos diversos espectros ideológicos, as fusões e fissões entre os partidos, as participações em governos e plataformas eleitorais moldam os sistema partidários, configurando um quadro mais ou menos instável. Logo, a volatilidade não pode ser entendida apenas como uma expressão da fragilidade do quadro partidário.

Barnes et alii (1985), analisando o caso espanhol, um outro caso da terceira onda de democratização, argumentam que a formação de um quadro ideológico mais ou menos estável, no nível do eleitorado, pode ocorrer mesmo que o sistema partidário não possua fortes ligações com a sociedade civil e não seja baseado em clivagens sociais 
históricas. A estrutura da competição, pode-se completar, pode criar a institucionalização dos partidos. Esse é o ponto também defendido neste trabalho.

\section{A unidade de análise}

Os estudos de política comparada com freqüência afirmam que o Brasil apresenta um dos sistemas eleitorais mais desfavoráveis à construção de imagens partidárias estáveis e coesas, ao voto partidário, em suma, ao fortalecimento dos partidos. (cf., dentre outros, o clássico Carey e Shugart, 1995). Essas assertivas são feitas tendo em vista a regra eleitoral para os cargos legislativos: a representação proporcional de lista aberta, com média-alta magnitude. No entanto, muitas vezes não é

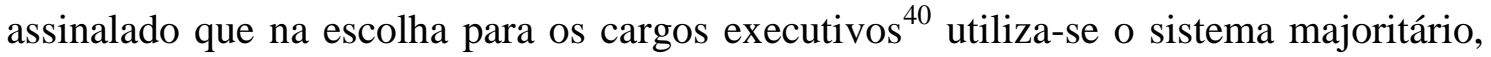
com pluralidade ou com segundo turno. Os impactos dessa dupla configuração institucional foi pouco notado pela literatura ${ }^{41}$.

As análises sobre o quadro partidário brasileiro em geral, e sobre a volatilidade eleitoral em particular, se pautam, quase que exclusivamente, em análises das disputas legislativas. Por certo, existem motivos para tal: (1) nessas eleições o custo de entrada é baixo, facultando a quase todos os partidos a participação; (2) dada a alta magnitude, não existirem incentivos para o voto estratégico ${ }^{42}$; (3) mas principalmente, acredito, essa escolha deriva da apropriação do debate tal como ele surge na literatura européia, que, de fato, utiliza as eleições legislativas como unidade de análise. Não poderia ser diferente, visto que o parlamentarismo é o sistema de governo predominante naquele continente, e, logo, as eleições para o legislativo nacional configuram, também, a formação do executivo.

No entanto, o caso brasileiro foge a esse modelo. Neste trabalho, defendo que as análises sobre o quadro partidário-eleitoral brasileiro devem se pautar na centralidade da disputa para os cargos majoritários. A estrutura de incentivos gerada pelas instituições

\footnotetext{
${ }^{40}$ A exceção a essa dicotomia é o cargo de senador.

${ }^{41}$ Uma exceção recente é Cortez (2009). Nicolau e Schmitt (1995) afirmam que mesmo as características do sistema eleitoral proporcional não levam necessariamente à fragmentação partidária.

${ }^{42}$ Praça (2007) estuda essa questão para a eleição de vereadores em São Paulo, afirmando que, de fato, a estrutura institucional desse tipo de pleito não possibilita o comportamento estratégico, ou a coordenação eleitoral.
} 
políticas brasileiras confere prioridade às disputas para o executivo, tanto aos partidos e candidatos, quanto aos eleitores.

Sendo os partidos office e/ou policy seeking, sua melhor estratégia é maximizar as chances de vitória nos pleitos de Presidente, governador e prefeito, pois é sabido que os recursos legislativos e orçamentários encontram-se nas mãos do Executivo ${ }^{43}$. Do ponto de vista dos eleitores, também existem indicações teóricas e empíricas nesse sentido. Carey (1997: 72) afirma que "where executives and legislatures are both popularly elected, executive elections tend to be more salient to voters than legislative elections". Singer (2000: 18) afirma, numa nota de rodapé, "como se sabe, no Brasil, a eleição presidencial tem um papel estruturador do sistema partidário".

Se a intenção é verificar em que medida os partidos políticos estão institucionalizados, em que grau existe um alinhamento com o eleitorado, etc., pode-se afirmar que o objeto analítico privilegiado deve ser os cargos mais importantes para os partidos, para o eleitorado e para o sistema político como um todo.

O movimento que proponho, de centralidade da competição para o executivo, se assemelha, em que pese diferenças de grau, ao proposto por Lavareda no debate sobre o sistema partidário de 1946. Ao discutir as teses sobre o período, conforme assinalamos anteriormente, o autor afirma que:

"as evidências que teriam corroborado as diferentes hipóteses (...) foram colhidas, na esmagadora maioria dos casos, apenas de eleições disputadas sob a regra de representação proporcional (...). Ficaram assim excluídas de observação detalhada as eleições majoritárias, dentre essas, as eleições presidenciais, as quais, afora a óbvia importância que decorre da massa de poder tradicionalmente concentrada no nível executivo no Brasil, cumprem, adicionalmente, o especial papel de serem os principais momentos de nacionalização da política” (Lavareda, 1991: 26).

Não se trata de desconsiderar a importância política e analítica das disputas legislativas. O ponto que quero levantar é: a preocupação teórica central que está por trás do debate da volatilidade eleitoral, qual seja, relação partido-eleitor, representação

\footnotetext{
${ }^{43}$ Cortez (2009) discute a "divisão do trabalho partidário" estimulada pela configuração das instituições políticas.
} 
política, institucionalização partidária e democrática, encontra, no Brasil, uma aplicação empírica mais acurada nas disputas para executivo.

Uma das visões que contribuem para minimizar as disputas majoritárias das análises sobre o quadro partidário brasileiro é a da que essa competição é permeada por fatores personalistas dos candidatos, não indicando verdadeiramente a força dos partidos. No entanto, como corretamente chama atenção Cortez (2009: 32), se partidos são definidos como organizações que buscam os votos dos cidadãos, logicamente não se pode afirmar que a dinâmica das eleições majoritárias, as mais importantes, diga-se novamente, atua à margem da estrutura dos partidos: "é de se esperar que partidos que disputam eleições majoritárias recorram a formatos diversos daquelas organizações que competem apenas na arena legislativa”.

Aldrich (1995) ajuda a trazer elementos interessantes. O autor defende que o formato e as características dos partidos individuais e do sistema partidário como um todo são instituições endógenas, fruto da ação dos políticos individuais. As ambições desses políticos, entretanto, não são partidárias em si, mas sim têm como metas políticas e cargos. Os partidos são apenas meios, e como tais, são passíveis de receber diversas configurações. Ademais, é crucial para as estratégias de ação dos atores políticos nesse campo a configuração político-institucional geral. O sistema de governo, o modo de organização interna do Legislativo, a estrutura federativa, etc., modelam os objetivos dos políticos, e, logo, incidem sobre o formato do sistema partidário.

As estratégias eleitorais e o tipo de linkage que os partidos estabelecem com os cidadãos no Brasil assumem contornos e conteúdos diferentes quando se trata de cargos proporcionais e quando se trata de cargos majoritários. No que se refere ao primeiro, um conceito que recentemente vem recebendo atenção da literatura nacional é o de “conexão eleitoral". Trata-se de um argumento desenvolvido para compreensão da ação legislativa dos congressistas americanos, dada a estrutura de incentivos da arena eleitoral. A visão clássica é que políticos buscariam recursos distributivos para seus distritos eleitorais, como forma de maximizar a probabilidade de reeleição. Alguns autores adaptam esse modelo para o Brasil, argumentando que no momento eleitoral os partidos políticos brasileiros não são muito diferentes de uma constelação de agentes individuais com comportamento paroquial. (cf. Ames, 1995a e 1995b; Pereira e Muller, 2003). 
Assim, Pereira e Muller (2003) defendem que, dada a estrutura das relações Executivo-Legislativo fortemente centralizada nos partidos, e dada a "conexão eleitoral" na arena parlamentar, os partidos políticos brasileiros seriam "fortes na arena legislativa e fracos na arena eleitoral". Cabe sublinhar que para realizar essa afirmação os autores se concentram nas disputas legislativas.

Acredito que essa afirmação representa um desafio para uma maior compreensão teórica e analítica dos partidos brasileiros, e da sua relação com o eleitorado. No presente trabalho, meu foco é no jogo eleitoral da arena executiva, e da discussão sobre volatilidade nesse cenário. Meu argumento é o de que a estabilidade eleitoral é considerável, mais alta do que a literatura normalmente supõe. Pesquisas futuras podem aclarar a relação entre as disputas executivas e legislativas, e em que medida os líderes partidários não tem capacidade efetiva de coordenar a competição na arena proporcional.

\section{Hipótese e interpretação.}

A hipótese que procurarei defender nesse trabalho é o de que a volatilidade eleitoral no Estado de São Paulo não revela um quadro instável e caótico, no qual os partidos pouco importariam para a decisão do eleitor. Antes, procurarei ressaltar que a dinâmica partidário-eleitoral no longo e no curto prazo revela razoável estabilidade. No longo prazo, a flutuação eleitoral deve ser compreendida como inserida em três contextos diferentes: a redemocratização dos anos 80; a remodelagem do quadro partidário provocada pela vitória e decadência do governo Collor; e a bipolaridade nacional construída nos anos 90 e 2000 entre PT e PSDB.

Os fatores de curto prazo dizem respeito às decisões de entrada dos partidos em cada pleito específico. Essas decisões são estratégias partidárias condicionadas por diversos fatores: a probabilidade de chance de vitória, a intenção de não ajudar a eleger adversários ideológicos, a busca de formação de uma imagem política de longo prazo, a busca por maximizar votos em outros pleitos (legislativos concomitantes, e as outras nos dois anos seguintes), etc. O ponto a ser ressaltado é o de que os eleitores têm seu comportamento restrito pela oferta de candidaturas, que formata o espaço político da competição. 
A estratégia metodológica adotada aqui será a separação analítica do índice de volatilidade em duas partes: a flutuação induzida ou necessária pela alteração do lançamento de candidaturas e a flutuação das preferências propriamente dita.

Para tanto, analisaremos como seria o índice de volatilidade se os partidos fossem constantes na entrada do jogo eleitoral. Trata-se, portanto, de uma abordagem contrafactual.

Uma análise contrafactual permite aprimorar as teorias explicativas. Trata-se de fazer inferências sobre uma relação de causa-efeito por meio de cenários hipotéticos (Fearon, 1991; Tetlock e Belkin, 1996). No caso ora em tela, o argumento contrafactual será usado como forma de averiguar em que medida a flutuação do voto capitada pelo índice de Pedersen é formada por mudanças no leque partidário ofertado ao eleitor, que impactam necessariamente na volatilidade. Levando em consideração que os cidadãos se manifestam apenas de acordo com o quadro que lhes é apresentado pelas elites políticas, a contrafactualidade é utilizada como forma de mensurar a volatilidade "descontando" as variações das candidaturas apresentadas pelos partidos. Trata-se, portanto, de uso de uma forma simples da metodologia contrafactual.

Como exemplo, imagine-se o seguinte caso, semelhante ao discutido acima: numa eleição T1, competiram o partido A, B e C, com a seguinte distribuição dos votos:

\begin{tabular}{cc}
\multicolumn{2}{c}{ Quadro 4 - Eleição em T1 } \\
\hline \hline Partidos & $\%$ Votos \\
\hline A & 40 \\
B & 30 \\
C & 30 \\
\hline \hline
\end{tabular}

Fonte: Elaboração Própria

Já no pleito T2, o partido C se retira, e D entra no pleito:

\begin{tabular}{cc}
\multicolumn{2}{c}{ Quadro 5 - Eleição em T2 } \\
\hline Partidos & $\%$ Votos \\
\hline A & 30 \\
B & 40 \\
D & 30 \\
\hline \hline
\end{tabular}

Fonte: Elaboração Própria 
O índice de volatilidade de Pedersen, nesse caso, seria de $40 \%$. No entanto, os eleitores de $\mathrm{C}$ em $\mathrm{T} 1$ foram impossibilitados de repetir sua preferência partidária em T2, e os eleitores de D de votarem sinceramente em T1. O índice de volatilidade, assim, é composto tanto de flutuação entre as legendas constantes quanto de mudanças de voto necessárias pelas decisões de entrada partidárias. Se considerássemos apenas as mudanças de voto dos partidos constantes, a volatilidade seria de $10 \%$. Assim, $30 \%$ dos eleitores flutuantes nesse cenário hipotético assim o são pelo movimento das elites partidárias.

Powell e Tucker (2009) dividem o índice de volatilidade de Pedersen em duas medidas: uma que abarca os partidos constantes e outra que diz respeito a legendas que participam apenas de um dos dois pleitos utilizados no cálculo do índice. Os autores afirmam que esses fenômenos dizem respeito a duas questões teóricas diferentes, e que estas são embaralhadas quando se utiliza a medida tradicional de Pedersen. O objetivo de Powell e Tucker é mostrar que a volatilidade em novas democracias (no caso, o Leste Europeu) é fruto, em grande medida, do aparecimento e desaparecimento de partidos, revelando as dificuldades de institucionalização do quadro partidário.

Utilizarei aqui a volatilidade dos partidos "flutuantes" para averiguar o quanto o índice de Pedersen calculado para os casos analisados se deve à entrada e saída de legendas. No entanto, a interpretação substantiva que darei é diversa da de Powell e Tucker (2009), por motivos expostos ao longo deste trabalho ${ }^{44}$. O procedimento matemático é o seguinte: $\mathbf{V F}=(\mathbf{P v}+\mathbf{P n}) / 2$,

Onde, $\mathrm{VF}=$ Volatilidade dos partidos "flutuantes"; $\mathrm{Pv}=$ proporção de votos dos partidos "velhos", ou seja, que participaram apenas da eleição do tempo 1, Pn= proporção de votos dos partidos "novos", ou seja, que participaram apenas da eleição do tempo 2.

Assim, o cenário da volatilidade contrafactual é formado por:

$$
\mathrm{VC}=\mathrm{VT}-\mathrm{VF},
$$

\footnotetext{
${ }^{44}$ Ademais, os autores utilizam eleições legislativas como objeto de análise, diferentemente desta pesquisa, focada nas eleições para o executivo.
} 
Onde VC = Volatilidade contrafactual; VT= Volatilidade Total (de Pedersen); $\mathrm{VF}=$ Volatilidade dos partidos "flutuantes". Esse seria o índice de volatilidade se os partidos fossem constantes na entrada, em cada par de eleições.

O "índice de volatilidade contrafactual" é útil para mostrar o quanto do nível de instabilidade eleitoral é fruto necessário das estratégias de entrada dos partidos, supondo-se que os eleitores se mantenham constantes.

\section{Ideologia e comportamento eleitoral}

Proponho neste trabalho que partidos e eleitores podem ser elencado em um contínuo ideológico unidimensional, e que esta dimensão é importante para a compreensão dos resultados eleitorais.

Existe um debate na literatura nacional sobre a importância da ideologia para entender o comportamento dos partidos políticos brasileiros. $\mathrm{Na}$ arena legislativa, Figueiredo e Limongi (1999: 75) afirmam que "podemos falar tranquilamente em partidos de direita, de centro e de esquerda". Zucco (2009) e Leoni (2002), por outro lado, considerando dados referentes a mais de um governo, defendem que o comportamento legislativo das legendas partidárias é pautado mais pela posição governo-oposição do que pela ideologia.

$\mathrm{Na}$ arena eleitoral, Singer (2000) defende que os eleitores brasileiros apresentam uma intuição ou sentimento ideológico, e que sua auto-localização na escala direitaesquerda encontra reflexo na direção partidária de seu voto. Mainwaring, Meneguello e Power (2000: 69), por seu turno, afirmam que "o caso brasileiro no período pós-1985 move-se em direção oposta à experiência da Europa Ocidental, sobre a qual Lipset baseou sua afirmação [de que eleitores de baixa renda votam principalmente em partidos de esquerda, e os de mais alta renda nos partidos de direita]".

Vê-se, assim, que existe grande debate nesse ponto. Esta dissertação segue a discussão e reelaboração efetuada por Sartori (1982) do modelo de Downs (1999), e defende que a dinâmica e a estrutura da competição eleitoral leva a um alinhamento unidimensional dos partidos. Os partidos, ao elaborarem distinções mútuas, com base em suas imagens e posições de políticas, conformam o espaço da competição política: “a competição [eleitoral] pressupõe um terreno comum no qual dois partidos (pelo menos) falam aos mesmos eleitores" (Sartori, 1982: 371). 
Assim, a aplicabilidade do modelo ideológico para o caso brasileiro (paulista, mais especificamente) não se baseia na compreensão, percepção ou avaliação do conjunto do eleitorado sobre as questões políticas e ideológicas. As elaborações cognitivas efetuadas pelos cidadãos devem ser objeto de outros trabalhos. Aqui, adotam-se dois pontos.

O primeiro ressalta a proeminência dos partidos, vis-à-vis os eleitores, na conformação dos parâmetros do jogo eleitoral. Os primeiros têm certa liberdade para ditar os temas em disputa, os objetos de contenda política. Esse é um dos principais pontos da contribuição de Schumpeter (1984) para uma visão empírica da democracia.

Evidentemente, as elites políticas não têm total grau de liberdade em suas ações. Schumpeter bebeu em boa medida em certas visões da psicologia de massas, que ressaltavam a irracionalidade do comportamento das massas. Hoje se sabe que essa caracterização carrega grandes exageros. No entanto, isso não pode levar ao descarte da idéia da primazia dos partidos.

O outro ponto a ser destacado é a não associação direta que existe entre as opiniões e avaliações dos eleitores sobre os partidos e a política de um modo geral, e a direção partidária de seu voto. Como bem sintetizou Sartori (1982: 370), existe uma diferença entre "as opiniões e a percepção geral da política registrada pelas entrevistas e a escolha eleitoral real". Esse ponto procura fazer um contraponto a Stokes (1965), quando este critica a aplicação empírica do modelo espacial de Downs baseado em resultados de surveys nos quais os eleitores expressavam não enxergar o mundo político em termos ideológicos e unidimensionais.

Entretanto, o ponto aqui levantado ressalta que decisão do voto é resultado de uma série de filtros cognitivos realizados pelo eleitor (para ficar na metáfora da escola de Michigan, da qual Stokes fazia parte). Suas opiniões mais gerais sobre o mundo político têm relação indireta com o voto depositado na urna. Assim como não se pode inferir do resultado eleitoral as motivações do sufrágio, não se pode deduzir críticas dirigidas a um modelo abstrato baseadas unicamente em opiniões dos cidadãos captadas em entrevistas. O modelo ideológico aqui levantado diz respeito apenas à lógica da competição eleitoral. 
Ao contrário de Sartori (1982), no entanto, que defende que as noções de esquerda e direita são rótulos razoavelmente vazios, mantenho um dos aspectos substantivos da noção de ideologia: a correlação dos votos dos partidos de diferentes espectros com a posição sócio-econômica dos eleitores. Em outras palavras, mantenho a expectativa teórica de que partidos de esquerda devem receber mais votos de eleitores mais pobres, enquanto que os localizados à direita obtenham maior apoio dos mais abastados.

Essa abordagem é tradicional na sociologia eleitoral e na noção de clivagem social da literatura sobre volatilidade. Em ambas, o que é ressaltado é a importância do constrangimento exercido pelos grupos sociais na direção do voto do eleitor. No longo prazo, a clivagem apontada por grande parte da literatura como a mais importante é a classista: as diferentes posições sócio-econômicas de eleitores e partidos modelariam seus comportamentos políticos.

Como ressalta Kitschelt (2000: 846), no entanto, este padrão teórico de associação entre posição social e localização ideológica é similar também no modelo espacial, ancorado na teoria da escolha racional. As preferências representadas nesse modelo estariam ligadas ao conflito esquerda-direita, e o posicionamento dos eleitores é fruto de seus interesses dados exogenamente ao modelo. O exógeno, no caso, é quase sempre a posição na divisão econômica da sociedade.

Assim, a despeito das suas diferenças, a literatura sobre clivagens sociais e volatilidade, e as teorias sociológicas e racionais do comportamento eleitoral levam a prescrições teóricas semelhantes: eleitores e partidos se relacionam intermediados por sua posição na estratificação social.

Evidentemente, esses são modelos de relação partido-eleitor abstratos e gerais. A adequação empírica sofre diversas intervenções de mecanismos diferentes, dentre eles: (1) o voto econômico, ou seja, comportamento eleitoral baseado em avaliações do desempenho do governo ou das políticas públicas, e a "compra" de apoio por políticas públicas, portanto, em alguma medida não totalmente correlacionado com posição ideológica/espacial (Powell Jr. e Whitten, 1993; Cox e MucCubbins, 1986) (2) a estrutura partidária, uma variável pouco levada em consideração para o estudo da competição eleitoral, principalmente no Brasil, mas importante se se quer analisar a relação partido-eleitor. Como exemplo, pode ser destacado Guarnieri (2011), que 
procura mostrar como as diferentes estruturas internas dos partidos brasileiros influenciam nas suas decisões de entrada nas eleições, e Calvo e Murillo (2004), que endereçam a importância da organização dos partidos na eficácia eleitoral de políticas públicas.

Em suma, a intenção nesta seção é defender e explicitar em que sentido a noção de ideologia será utilizada na análise dos resultados eleitorais e da volatilidade eleitoral, e ressaltar "variáveis intervenientes" importantes para formatar o espaço de competição política.

\section{Estrutura dos dados}

Neste trabalho, utilizo dois tipos de dados: o percentual de votos válidos e o nível de educação do eleitorado. Ambos foram fornecidos pelo TSE (Tribunal Superior Eleitoral) ao subprojeto "Política e Comportamento Eleitoral", abarcado no projeto do CEM (Centro de Estudos da Metrópole), sediado no Cebrap (Centro Brasileiro de Análise e Planejamento). A variável educação é chave em diversas perspectivas discutidas ao longo deste trabalho: para as teorias da modernização e do desenvolvimento político, o eleitorado com baixa educação, pobre e marginalizado socialmente tende a comportamentos políticos radicalizados. Para as teorias sociológica e psico-sociológica do comportamento eleitoral, cidadãos com menor nível educacional são mais propensos à mudança de voto, devido à sua frágil inserção em grupos que condicionam comportamentos políticos e/ou à sua particular (tosca e inconstante) apreensão cognitiva do mundo político. Por outro lado, pode-se afirmar que visões que ressaltam a importância do clientelismo em cidades pequenas levam a crer que eleitores pobres situados nessas localidades seriam constantes em seu comportamento eleitoral. Essas diferentes visões sobre a relação entre características sociais dos eleitores e estabilidade/instabilidade da direção do voto serão testadas empiricamente para o caso paulista.

Os votos são trabalhados em três níveis de agregação: o estado de São Paulo, as cidades que o compõe, e as seções eleitorais (urnas). Devido à disponibilidade dos dados, os dois últimos são possíveis apenas a partir de 94 . O estado é hoje composto por 645 municípios, sendo que em 1994, primeiro ano da presente pesquisa, o era por 625. Segue abaixo o número de urnas em cada pleito: 
Tabela 1 - Número de Seções consideradas

\begin{tabular}{lcccccccc}
\hline \hline Ano eleitoral & 1994 & 1996 & 1998 & 2000 & 2002 & 2004 & 2006 & 2008 \\
\hline Número & 42019 & 13128 & 44673 & 13951 & 49414 & 17005 & 66281 & 20301 \\
\hline \hline
\end{tabular}

Fonte: Banco de dados Eleitorais CEM/CEBRAP

A identificação das urnas no tempo é possível por meio de um código de identificação. Assim, pode-se trabalhar com as informações referentes a esse nível de agregação em qualquer dos pleitos contemplados dessa pesquisa, desde que a mesma não seja excluída pelo TSE. Além disso, foi possível também obter informação, por meio de um arquivo cedido pelo Tribunal Eleitoral, sobre transferência de urnas, ou seja, seções eleitorais que foram agregadas, desagregadas ou alteraram seu código entre 2000 e 2009. Dessa forma, foi possível minimizar as perdas de urnas e eleitores.

A desagregação por urnas possibilita minimizar o efeito da falácia ecológica. Como colocado no início deste capítulo, esse é um dos principais debates metodológicos sobre o índice de Pedersen. Um dos exercícios que farei será a comparação da volatilidade agregada pelo Estado (ou pelo município, no caso das eleições de prefeito) com aquela calculada sobre as urnas.

O nível de educação foi obtido pelas informações constantes no Cadastro Eleitoral. Trata-se de um banco de dados organizado pelo TSE com informações sobre o eleitorado, tais como o nível educacional, a data de nascimento, o sexo, entre outras, fornecidas pelo cidadão no momento do alistamento eleitoral ou de transferência de seu local de votação. O banco aqui utilizado foi atualizado no início de 2009. De acordo com sua escolaridade, cada eleitor recebeu os seguintes valores:

Quadro 6 - Codificação de Escolaridade no Cadastro Eleitoral

0 Não informado

1 Analfabeto

2 Lê e escreve

3 Fundamental incompleto

4 Fundamental completo

5 Ensino Médio incompleto

6 Ensino Médio completo

7 Superior incompleto

8 Superior completo

Fonte: Banco de dados Eleitorais CEM/CEBRAP 
Assim, o procedimento adotado nesta pesquisa consistiu na soma do valor de escolaridade de todos os eleitores em cada urna e posterior divisão dessa soma pelo total de eleitores aptos a votar. Assim, tem-se a escolaridade média de cada seção.

Os valores assumidos nos diferentes anos em São Paulo são:

Tabela 2 -Distribuição da Educação por seção

\begin{tabular}{lrrrrrrrr}
\hline \hline Ano Eleitoral & 1994 & 1996 & 1998 & 2000 & 2002 & 2004 & 2006 & 2008 \\
\hline Média & 4,12 & 4,44 & 4,1 & 4,43 & 4,12 & 4,46 & 4,23 & 4,51 \\
Desvio-Padrão & 0,73 & 0,78 & 0,71 & 0,77 & 0,71 & 0,75 & 0,7 & 0,75 \\
\hline \hline
\end{tabular}

Fonte: Banco de dados Eleitorais CEM/CEBRAP

Alguns esclarecimentos quanto aos dados utilizados nessa pesquisa. Em primeiro lugar, o Banco do Cadastro de Eleitores é do ano do início de 2009, e portanto, diz respeito à inscrição e distribuição dos eleitores tais como se encontravam naquele momento. Logo, devo assumir que a educação média das urnas manteve-se mais ou menos constante de 94 a 08 . O segundo diz respeito à perda de seções e, logo, de votos, quando se junta informações, tais como votos e educação, devido à extinção e criação de urnas no passar dos anos. No anexo encontra-se o percentual de votos válidos que se mantiveram. Por fim, tem-se o problema da falácia ecológica, no sentido de que uma urna com alta educação, por exemplo, não implica que todos seus eleitores tenham essa característica.

Os níveis educacionais serão utilizados em duas questões analíticas: a) verificar se as taxas de volatilidade têm relação com o nível educacional dos eleitores; b) verificar se partidos têm bases sociais/educacionais identificáveis e/ou diferenciadas. Para realizar ambos os procedimentos, farei dois testes empíricos: para cada par de eleição (no caso do teste a) e eleição individual (no caso do teste b) ordenarei crescentemente as urnas de acordo com o nível educacional, e separarei por quartis em número igual de seções. O primeiro quartil contém as $25 \%$ das urnas de menor escolaridade, o segundo as $25 \%$ seguintes, e assim sucessivamente. Dessa forma, compararei os índices de volatilidade e os votos dos partidos nos diferentes quartis. $\mathrm{O}$ outro teste consiste na correlação entre ambas as medidas e o nível educacional por urna. Neste último procedimento, para efeito de comparação entre os valores de associação encontrados nos diferentes tempos e espaços, utilizarei os coeficientes não padronizados de uma análise de regressão linear simples: como variável dependente 
será utilizada o índice de volatilidade em um modelo, e a porcentagem de votos dos partidos em outro; e educação média da urna será a variável independente utilizada. Isso é necessário, pois, como ressaltam alguns autores (Achen, 1977; King, 1986: 674-5; Filho e Júnior, 2009) o coeficiente de correlação de Pierson é sensível ao tamanho da amostra, podendo, por isso, assinalar coeficientes de magnitude diferentes para associações semelhantes, devido a diferenças no número de casos considerados.

Devido à estrutura dos dados, necessariamente agregados, todas as análises que serão feitas não se aplicam ao comportamento do eleitor individualmente. Análises de inferência ecológica, de padrões contextuais, e outros exercícios podem ser realizados em futuras oportunidades.

As unidades do índice de Pedersen aqui utilizadas são as votações dos partidos individuais, desconsiderando votos brancos e nulos. As referências aos blocos ideológicos serão feitos na análise do contexto de cada disputa, e não na configuração formal do índice de volatilidade, como proposto por Bartolini e Mair (1990). A intenção deste trabalho é averiguar o que a volatilidade está revelando: se um eleitorado inconstante, volúvel e idiossincrático, e, como contrapartida, um sistema partidário fluído e não enraizado; ou se antes, efeitos de estratégias eleitorais de partidos, que atuam sobre um eleitorado razoavelmente constante do ponto de vista ideológico.

A unidade de análise escolhida são as disputas para os de governador no Estado de São Paulo, de prefeito da capital e os resultados do pleito presidencial no Estado. O recorte temporal vai de 1982 a 2008, cobrindo o período da redemocratização até o último pleito municipal realizado. No entanto, por razões da disponibilidade de dados desagregados por urna, a análise se concentrará no período pós 1994. Cabe notar que este recorte "técnico" coincide com uma importante questão substantiva deste trabalho: o sistema partidário brasileiro toma, a partir das eleições presidenciais de 94, um novo, e até agora estável, formato: a polaridade PT-PSDB, que estrutura a dinâmica partidário-eleitoral brasileira.

\section{Caso escolhido}

O cenário eleitoral paulista ao mesmo tempo reflete e influencia o quadro nacional. Reflete porque reproduz, não sem especificidades importantes que serão discutidas, a configuração partidário-eleitoral federal. Influencia pelo seu peso histórico, 
econômico e pelo tamanho do seu eleitorado. Em 2006, cerca de $22 \%$ dos aptos a votarem nacionalmente se encontravam em São Paulo. Ademais, é nele que se formaram as duas principais agremiações partidárias que estruturam a competição para o executivo nacional: o PT, formado em 1980 tendo com embrião o novo movimento sindical da Grande São Paulo, e o PSDB, fruto de uma dissensão do PMDB em 1988. Esses aspectos justificam um estudo centrado nesse estado.

No que diz respeito à estrutura do sistema partidário-eleitoral no período aqui estudado, além da presença forte de PT e PSDB, outro fator a ser destacado é que uma força representante da direita (o PP) constantemente disputou os cargos de governador e prefeito da capital, abrindo duas possibilidades de pesquisa: (1) verificar se esses três partidos têm bases eleitorais distintas e condizentes com sua posição no espectro ideológico, e (2) verificar como se deu a perda de força do PP e a construção da polaridade PT-PSDB no Estado de São Paulo, no que diz respeito à volatilidade por diferentes níveis de escolaridade.

Assim, este trabalho constitui o que Gerring (2004: 342) define como estudo de caso: "an intensive study of a single unit for the purpose of understanding a larger class of (similar) units”. Dessa forma, a hipótese e a metodologia são aqui aplicadas para o Estado de São Paulo e suas cidades, mas têm a pretensão de serem testadas e aprimoradas em outras unidades da federação, de modo à melhor compreender as características da competição partidário-eleitoral no Brasil. 


\section{Capítulo IV - Eleições e Volatilidade em São Paulo}

Neste capítulo apresento a análise empírica das eleições para governador de São Paulo, entre 1982 e 2006, os resultados das presidenciais neste estado, de 1989 a 2006, e prefeito da capital, de 1985 a 2008, com ênfase no período pós 1994, discutindo a questão da volatilidade eleitoral. Diversos testes, expostos no capítulo III, serão realizados para verificar até que ponto o eleitor paulista e paulistano pode ser caracterizado como volátil.

O conceito e o índice de volatilidade eleitoral incide sobre a dinâmica temporal da relação partido-eleitor, e, de acordo com a visão dominante da literatura comparada e nacional, apresenta no Brasil valores elevados, indicando que os partidos não conseguiriam criar raízes estáveis no eleitorado. Contrariamente, a interpretação que busco oferecer nesta dissertação procura sublinhar a relativa estabilidade encontrada nos resultados eleitorais em São Paulo.

\section{Eleições presidenciais 1989-2006}

As eleições presidenciais brasileiras assumiram dois formatos diferentes no período atual da Nova República: o primeiro vigorou, na verdade, em uma única eleição, na inaugural, de 1989; e o segundo ditou a competição eleitoral no período seguinte, de 1994 a 2006.

O pleito presidencial de 1989 representou o ápice de certos diagnósticos sobre o sistema partidário brasileiro: mais de 20 candidatos concorreram, todos os grandes partidos lançaram plataformas, o PMDB, maior partido até então, amealhou míseros 4\% dos votos, e a vitória coube a um político e principalmente um partido outsiders. Logo, o quadro parecia corroborar avaliações sobre a fragilidade dos partidos no Brasil.

No entanto, o resultado eleitoral de 1989 em nada ajuda a compreender a dinâmica partidário-eleitoral posterior. A partir de 1994, como já notado por parte da literatura (Limongi e Cortez, 2010; Melo, 2007), as eleições presidenciais brasileiras são caracterizadas pela proeminência de PT e PSDB, seguidos por terceiras forças variáveis. Defendo que essa hegemonia é fruto de duas ordens de fatores: ambos os partidos foram 
capazes de impedir o estabelecimento de outros com ambições e fôlego de longo prazo, e, em cada eleição, lograram manter parcela de seu eleitorado constante. Deve-se ter em mente que este quadro mais amplo é crucial para o entendimento da volatilidade eleitoral nestes pleitos.

Abaixo se encontra as tabelas com os índices de volatilidade eleitoral de Pedersen para as eleições presidenciais no Estado de São Paulo. Primeiramente o valor agregado para todo o Estado de São Paulo:

Tabela 3 -Volatilidade eleitoral Pedersen - Presidente - Nível do Estado de São Paulo - \%

\begin{tabular}{ccccc}
\hline \hline 1989-1994 & $1994-1998$ & $1998-2002$ & $2002-2006$ & Média \\
\hline 55 & 14,7 & 35 & 34,7 & 34,8 \\
\hline \hline
\end{tabular}

Fonte: Banco de dados Eleitorais CEM/CEBRAP

Dois pontos chamam atenção: (1) o elevado patamar da flutuação entre 89-94, que faz sentido tendo em vista a reorganização do quadro partidário que ocorreu entre esse período; (2) mas também os não baixos índices nos dois últimos pares, que parecem não corroborar o argumento da estabilidade da bipolaridade da eleição presidencial.

Como dito no capítulo anterior, disponho dos dados eleitorais por urna. Assim, é possível descer o cálculo da volatilidade para esse nível de agregação. Esse procedimento, ainda que não elimine totalmente os problemas da inferência ecológica, pode revelar movimentações do eleitorado não captadas pelo índice de volatilidade agregado no nível do Estado. Abaixo se encontra tabelas com os resultados da volatilidade média por seção eleitoral e por município, em cada par. Note-se que não dispomos dos dados referentes a 1989. 
Tabela 4 - Volatilidade eleitoral - Presidente - Nível das seções eleitorais- \%

\begin{tabular}{lcccc}
\hline \hline & $1994-1998$ & $1998-2002$ & $2002-2006$ & Média \\
\hline Média & 16,8 & 34,7 & 36,1 & 29,2 \\
Máximo & 91,3 & 76,8 & 67,3 & 78,5 \\
Mínimo & 4,4 & 6 & 6 & 5,5 \\
D.P. & 5 & 6,7 & 7,8 & 6,5 \\
Mediana & 16,2 & 34,9 & 36,4 & 29,2 \\
$\mathrm{~N}$ & 40994 & 43560 & 47307 & \\
\hline \hline
\end{tabular}

Fonte: Banco de dados Eleitorais CEM/CEBRAP

Tabela 5 - Volatilidade eleitoral - Presidente - Nível dos municípios -

\begin{tabular}{lcccc}
\multicolumn{5}{c}{$\%$} \\
\hline \hline & $1994-1998$ & $1998-2002$ & $2002-2006$ & Média \\
\hline Média & 19,4 & 35,3 & 31 & 28,5 \\
Máximo & 55,8 & 51 & 54,6 & 53,8 \\
Mínimo & 9 & 13,1 & 9,7 & 10,6 \\
D.P. & 6,2 & 5,8 & 8,4 & 6,8 \\
Mediana & 18,1 & 35,5 & 31,7 & 28,4 \\
$\mathrm{~N}$ & 625 & 645 & 645 & \\
\hline \hline
\end{tabular}

Fonte: Banco de dados Eleitorais CEM/CEBRAP

A observação das tabelas revela que, de modo geral, não é grande a diferença entre os índices de Pedersen calculados com o máximo e o mínimo de agregação possíveis. As médias dos dados referentes às urnas pouco se distanciam das volatilidades agregadas ao nível estadual. No que diz respeito aos resultados municipais do índice, as médias do par 94-98 e 02-06 discrepam em relação ao Estado como um todo. Essas observações sugerem que (1) o nível de agregação importa para o cálculo da volatilidade, mas (2) não é unívoco que um nível mínimo de agregação produzirá, necessariamente, maior índice de volatilidade.

Por último, uma observação sobre a distribuição dos dados: nas seis observações, a mediana é muito semelhante à média, revelando uma distribuição simétrica.

Após a apresentação dos dados, passamos a questões analíticas. 


\section{Volatilidade contrafactual}

O objetivo nesta seção é procurar distinguir o quanto da volatilidade se deve à mudança de preferências do eleitor e quanto ela é condicionada pela alteração da oferta partidária. Evidentemente, os dois fenômenos estão relacionados, posto que a oferta de candidaturas depende das expectativas dos partidos quanto ao comportamento dos eleitores, mas essa separação analítica pode trazer ganhos interessantes.

As "entradas" e "saídas" de partidos grandes e médios entre 89 e 06 não foi pequena. Dessa forma, o eleitor teve a possibilidade de não se restringir à bipolaridade PT-PSDB, mas, ao mesmo tempo, foi impossibilitado muitas vezes de manter sua preferência partidária em dois pontos do tempo seguidos. Abaixo se encontra um quadro com a participação de partidos médios e grandes no pleito presidencial:

Quadro 7 - Eleições Presidenciais - Candidaturas por Partidos

\begin{tabular}{llllll}
\multicolumn{7}{c}{ Selecionados } \\
\hline \hline PT & 1989 & 1994 & 1998 & 2002 & 2006 \\
PDT & $\mathrm{X}$ & $\mathrm{X}$ & $\mathrm{X}$ & $\mathrm{X}$ & $\mathrm{X}$ \\
PSB & $\mathrm{X}$ & $\mathrm{X}$ & & & $\mathrm{X}$ \\
PCB/PPS & $\mathrm{X}$ & & $\mathrm{X}$ & $\mathrm{X}$ & \\
PSDB & $\mathrm{X}$ & $\mathrm{X}$ & $\mathrm{X}$ & $\mathrm{X}$ & $\mathrm{X}$ \\
PMDB & $\mathrm{X}$ & $\mathrm{X}$ & & & \\
PTB & $\mathrm{X}$ & & & & \\
PL & $\mathrm{X}$ & & & & \\
PFL/DEM & $\mathrm{X}$ & & & & \\
PDS/PP & $\mathrm{X}$ & $\mathrm{X}$ & & & \\
\hline TOTAL & 9 & 5 & 3 & 4 & 3 \\
\hline \hline
\end{tabular}

Fonte: TSE

Vê-se que ocorreu uma razoável movimentação do quadro de lançamento de candidaturas. Partidos médios e grandes entraram e saíram da competição. Note-se a queda drástica do número de competidores entre 89 e 94, processo este que se completa em 98 .

Logo, os eleitores puderam e/ou foram forçados, ao longo de 89-06, a alterar sua escolha eleitoral, sem que isso constitua própria ou necessariamente em volatilidade do eleitor. Digamos que um determinado eleitor tem preferência pelo PTB ou PL. Se este for o caso, ele só pode expressá-la em 1989. Ou, de outra forma, pense-se em um eleitor 
do PSB: ele só teve uma oportunidade de votar em seu partido, em 2002. Nas demais oportunidades ele teve que votar em sua segunda (ou terceira, ou quarta, etc.) preferência. Mais genericamente, se um partido está presente em T1, mas não em T2, então seus eleitores serão forçados a mudar seu voto em T2. De outro lado, para partidos que entram em T2, seus eleitores foram obrigados a votar em outros partidos em T1. Logo, dependendo da oferta de candidaturas, pode-se observar volubilidade eleitoral mesmo em um cenário em que eleitores têm preferências partidárias estáveis. Obviamente, não estou dizendo que isto aconteceu nesta ou naquela eleição, estou apenas chamando atenção para as duas facetas do fenômeno e notando que, para além do problema da falácia ecológica, o índice de Pedersen precisa ser interpretado com cuidado.

Assim, pode-se retirar, do índice de volatilidade apresentado acima, os votos dos partidos que "flutuaram" em cada par de eleições. Trata-se do índice de volatilidade contrafactual, tal como apresentado no capítulo III. Os apoiadores desses partidos entram necessariamente no índice de volatilidade, mas por fatores que escapam de sua discricionariedade: não puderam repetir sua preferência partidária em dois pontos do tempo por decisão partidária de entrada/retirada de candidatura.

Abaixo se encontram os índices de volatilidade contrafactual, compostos pela mudança de voto apenas dos partidos que apresentaram plataformas nas duas eleições de cada par. Estão excluídos, então, os votos dos eleitores que alteraram sua preferência "forçosamente" pelas decisões de entrada dos partidos.

Tabela 6 - Cenário Contrafactual -Volatilidade eleitoral Presidente - Nível do Estado de São Paulo - \%

\begin{tabular}{ccccc}
\hline \hline $1989-1994$ & $1994-1998$ & $1998-2002$ & $2002-2006$ & Média \\
\hline 51 & 6,3 & 26,1 & 17,5 & 25,6 \\
\hline \hline
\end{tabular}

Fonte: Banco de dados Eleitorais CEM/CEBRAP 
A análise deve seguir a comparação com os resultados da tabela 3: naquela estão os índices formados a partir dos votos em todos os partidos. Nessa, apenas dos partidos constantes. A diferença entre as duas mostra os eleitores que alteraram seu voto em função da mudança na oferta partidária.

A observação do valor médio dos quatro pares considerados em ambas as tabelas mostra que o cenário contrafactual reduz em cerca de $26 \%$ o índice de volatilidade. No entanto, o impacto da entrada e saída de partidos com votação relevante não foi similar em todos os pares de eleição. Notadamente, nota-se a pequena redução em 89-94. Tratase de mais uma evidência da excepcionalidade do pleito vencido por Collor.

Considerando as médias da volatilidade de Pedersen e da volatilidade contrafactual sem o primeiro par, $89-94$, tem-se que a primeira fica em torno de $28,1 \%$, enquanto a segunda alcança 16,6\%. Logo, a flutuação eleitoral necessariamente condicionada pela mudança da oferta partidária atinge $40 \%$ do índice total entre os pares 94-98, 98-02 e 02-06, nos resultados paulistas das eleições presidenciais brasileiras.

Das observações pontuais de cada par, chamam atenção: (1) a alta estabilidade eleitoral entre 94-98 nos dois cenários; (2) a alta flutuação entre os partidos constantes em 98-02 (valor de 26\% na tabela 6); (3) o alto impacto da mudança do quadro de candidaturas em $02-06$, com a volatilidade caindo de 34,7 para $17,5 \%$.

Logo, de fato ocorreram mudanças eleitorais tanto entre 1998 e 2002 quanto entre 2002 e 2006. No entanto, elas foram de caráter diferente: a primeira foi de maior impacto, e ocorreu notadamente entre os partidos que se mantiveram nos pleitos. Essas informações sugerem que a volatilidade eleitoral entre esses três pleitos se constituiu tanto por mudanças mútuas de voto entre PT e PSDB quanto pela força de novos partidos. Pelos resultados eleitorais nacionais e paulistas sabe-se que terceiras forças não foram capazes de quebrar a hegemonia de ambos os partidos. Algumas seções abaixo se dedicam a verificar se a transferência de apoio entre PSDB e PT configurou alterações nas respectivas bases eleitorais. 


\section{Volatilidade por educação}

O objetivo nesta seção é verificar se existe uma associação entre volatilidade nas eleições presidenciais e escolaridade. Como foi notado na construção teórica, a teoria do desenvolvimento político, que baliza parte da análise comparada da institucionalização do sistema partidário brasileiro, e algumas teorias do comportamento eleitoral motivam a visão de que eleitores de baixa educação são mais propensos a serem inconstantes. Assim, realizei dois testes: para cada par de eleições, elenquei todas as urnas em ordem crescente, da menor para a maior educação, e dividi em quartis. Logo, o primeiro quartil constitui-se nas $25 \%$ urnas com menor educação no Estado de São Paulo; o segundo quartil, nas $25 \%$ seguintes, e assim sucessivamente. Depois, calculei o índice de volatilidade de Pedersen para cada quartil. O segundo teste consiste num modelo de regressão linear simples, com a volatilidade como variável dependente, e a educação por urna como variável independente. O objetivo é ver o sinal e a força do coeficiente dessa variável, e compará-lo em todos os anos e com os testes da volatilidade de governador e prefeito. Devido à disponibilidade dos dados, essas análises empíricas apenas são possíveis a partir de 1994.

Tabela 7 -Volatilidade eleitoral - Presidente - Quartis educacionais - \%

\begin{tabular}{lccc}
\hline \hline Ano/Quartil & $1994-1998$ & $1998-2002$ & $2002-2006$ \\
\hline 1 quartil & 17,1 & 34,9 & 29,2 \\
2 quartil & 16,1 & 35,5 & 34,2 \\
3 quartil & 14,4 & 35,6 & 38,5 \\
4 quartil & 12,2 & 31,3 & 40,3 \\
\hline \hline
\end{tabular}

Fonte: Banco de Dados Eleitorais CEM/CEBRAP

Tabela 8 - Regressão Linear Simples - Volatilidade Eleitoral Pedersen / Educação - Presidente

\begin{tabular}{lccc}
\hline \hline Ano/Informações do Modelo & $1994-1998$ & $1998-2002$ & $2002-2006$ \\
\hline Coeficiente da V.I. & $-2,709$ & $-3,187$ & 4,291 \\
Erro-Padrão & 0,032 & 0,042 & 0,047 \\
Significância & $* * *$ & $* * *$ & $* * *$ \\
$\mathrm{R} 2$ & 0,151 & 0,115 & 0,151 \\
$\mathrm{~N}$ & 39950 & 43526 & 47307 \\
\hline \hline Variável Dependente: Volatilidade Eleitoral de Pedersen & & \\
Variável Independente: Média de Educação & & \\
Unidade: Seção Eleitoral & & \\
Significância: *** p<0,01 & & \\
Fonte: Banco de Dados Eleitorais CEM/CEBRAP &
\end{tabular}


A tabela 7 mostra o índice de volatilidade em cada quartil, nos três pares de eleição. Note-se que em 94-98 a flutuação tem queda linear quando se passa das seções de menor para as de maior educação, e, no último período analisado, 02-06, o padrão se inverte: o quartil de menor educação é o que apresentou menor volatilidade eleitoral. $\mathrm{O}$ par 98-02 não apresentou essa tendência direta, no entanto, o coeficiente da regressão exposto na tabela 8 revela que a escolaridade está negativamente associada à volatilidade, assim como em 94-98.

A força dessa relação em 02-06 é a mais alta dos três pares estudados, com o parâmetro do modelo de regressão atingindo 4,3, com sinal positivo. Logo, não se pode afirmar que eleitores com menor educação são inerentemente mais voláteis, ou viceversa. A mudança de voto parece ter mais relação com a dinâmica da competição eleitoral, as características e as forças dos partidos apresentados, do que com características sociais dos eleitores.

\section{Contrafactual por educação}

Tabela 9 - Cenário Contrafactual - Volatilidade eleitoral - Presidente Quartis educacionais - \%

\begin{tabular}{lcrc}
\hline \hline Ano/Quartil & 1994-1998 & 1998-2002 & 2002-2006 \\
\hline 1 quartil & 7,2 & 24,6 & 13,2 \\
2 quartil & 7 & 25,8 & 17 \\
3 quartil & 6,4 & 26,9 & 20,6 \\
4 quartil & 5 & 25,2 & 23,3 \\
\hline \hline
\end{tabular}

Fonte: Banco de Dados Eleitorais CEM/CEBRAP

Tabela 10 - Regressão Linear simples - Cenário Contrafactual / Educação Presidente

\begin{tabular}{lccc}
\hline \hline Ano/Informações do Modelo & $1994-1998$ & $1998-2002$ & $2002-2006$ \\
\cline { 1 - 3 } Coeficiente da V.I. & $-1,859$ & $-0,823$ & 3,99 \\
Erro-Padrão & 0,037 & 0,04 & 0,041 \\
Significância & $* * *$ & $* * *$ & $* * *$ \\
R2 & 0,058 & 0,009 & 0,165 \\
$\mathrm{~N}$ & 39950 & 43526 & 47307 \\
\hline \hline
\end{tabular}

Variável Dependente: Volatilidade Eleitoral Contrafactual

Variável Independente: Média de Educação

Unidade: Seção Eleitoral

Significância: $* * * \mathrm{p}<0,01$

Fonte: Banco de Dados Eleitorais CEM/CEBRAP 
Os índices de volatilidade contrafactual, ou seja, os valores da flutuação do voto como seriam se as opções partidárias permanecessem constantes, revelam que as diferenças entre os grupos educacionais são aplainadas: tanto os coeficientes do modelo de regressão linear simples quanto os valores por quartis de escolaridade mostram uma maior homogeneidade na relação entre volatilidade e escolaridade do que a encontrada nos testes com o índice de Pedersen, considerando todas as legendas. Esse dado revela que os partidos que mobilizaram o eleitorado mas não apresentaram plataforma em dois pleitos seguidos obtiveram inserção educacional específica, seja nos mais educados, seja nos menos.

\section{Votos por educação}

O objetivo aqui é levantar indícios sobre as bases sociais dos partidos. Verificaremos se os índices de volatilidade expostos acima expressam alterações na inserção social das legendas. Como vimos, o debate da volatilidade está assentado na noção de clivagens sociais, e a literatura sobre o Brasil reiteradamente afirma que os partidos não possuem lastro nos diferentes grupos da sociedade. Procura-se mostrar aqui, ao contrário, que PT e PSDB, os principais contendores de 94 a 06, se ancoram em grupos educacionais definidos, e que esse padrão não sofre alteração no tempo, no Estado de São Paulo.

Abaixo se encontram gráficos e tabelas de regressão sobre a relação entre voto no PT e PSDB e nível de escolaridade por urna. O primeiro exercício consiste numa divisão das urnas em quartis, ordenados crescentemente, das urnas de menor educação até as de maior, e a porcentagem de votos dos partidos nesses quartis. A atenção deve estar voltada para a comparação da disposição da reta entre os pleitos. No que se refere ao segundo teste, trata-se de um modelo de regressão simples, no qual a variável dependente é a porcentagem de votos do PT ou do PSDB, e a variável explicativa é o nível médio de escolaridade das urnas. Como dito no capítulo III, a intenção aqui é verificar a força e o sentido dessa relação, bem como se ocorreram mudanças ao longo do tempo.

Abaixo se encontram o gráfico e a tabela referentes ao PT: 


\section{Gráfico 1}

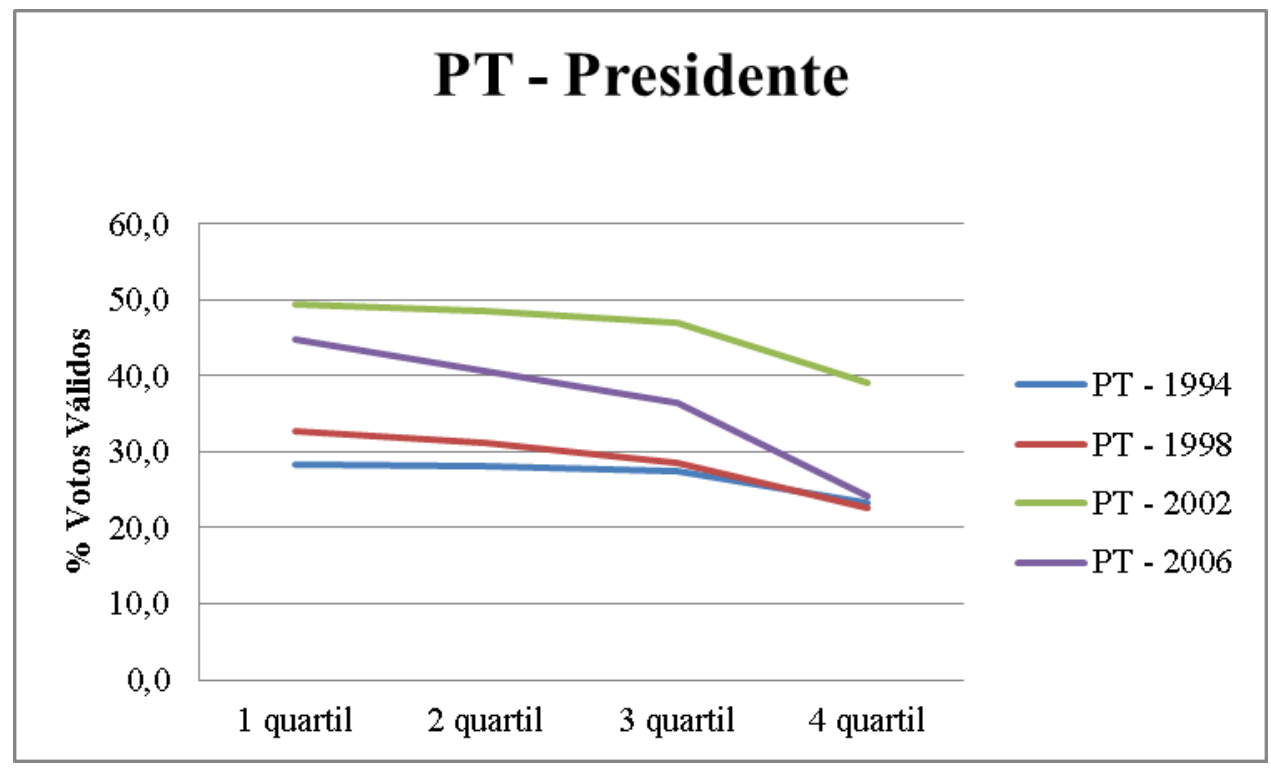

Tabela 11 - Regressão linear simples - PT / Educação - Presidente

\begin{tabular}{lcccc}
\hline \hline Ano/Informações do Modelo & 1994 & 1998 & 2002 & 2006 \\
\hline Coeficiente da V.I. & $-2,7$ & $-5,207$ & $-6,004$ & $-11,226$ \\
Erro-Padrão & 0,069 & 0,069 & 0,06 & 0,063 \\
Significância & $* * *$ & $* * *$ & $* * *$ & $* * *$ \\
R2 & 0,038 & 0,117 & 0,178 & 0,317 \\
$\mathrm{~N}$ & 38852 & 43527 & 46203 & 66281 \\
\hline \hline
\end{tabular}

Variável Dependente: \% Votos do PT

Variável Independente: Média de Educação

Unidade: Seção Eleitoral

Significância: *** $\mathrm{p}<0,01$

Fonte: Banco de Dados Eleitorais CEM/CEBRAP

Os dados mostram uma relação interessante: não apenas o PT esteve mais associado às urnas de menor educação em todo o período considerado, como também aumentou sua inserção entre esse grupo. O coeficiente da regressão é inequívoco: conforme ocorrem as disputas de 94, 98, 02 e 06, aumenta o impacto da variação da educação no voto do PT.

As diferenças entre o primeiro e o último quartil dispostos no gráfico também revelam esse padrão: em 94, foi de 5,2\%, em 98 e 02, foi de cerca de $10 \%$, e no último pleito, de 06 , foi de $20,5 \%$. 
Logo, o padrão de apoio do PT nas eleições presidenciais de 94-06 em São Paulo é condizente com o modelo sociológico ou espacial do comportamento eleitoral: sendo o competidor efetivo situado mais à esquerda, o partido de fato recebeu mais votos dos menos educados. Cabe notar que essa relação pode ter se aprofundado após o exercício do governo central a partir de 2003. Entretanto, é importante sublinhar que mesmo anteriormente, quando a legenda era oposição, a relação entre nível educacional e voto era a mesma. Assim, levantam-se indícios no sentido de sustentar a idéia de que o core voter do PT no Estado de São Paulo seja o eleitor menos educado.

Abaixo se encontra os mesmos dados referentes ao PSDB:

\section{Gráfico 2}

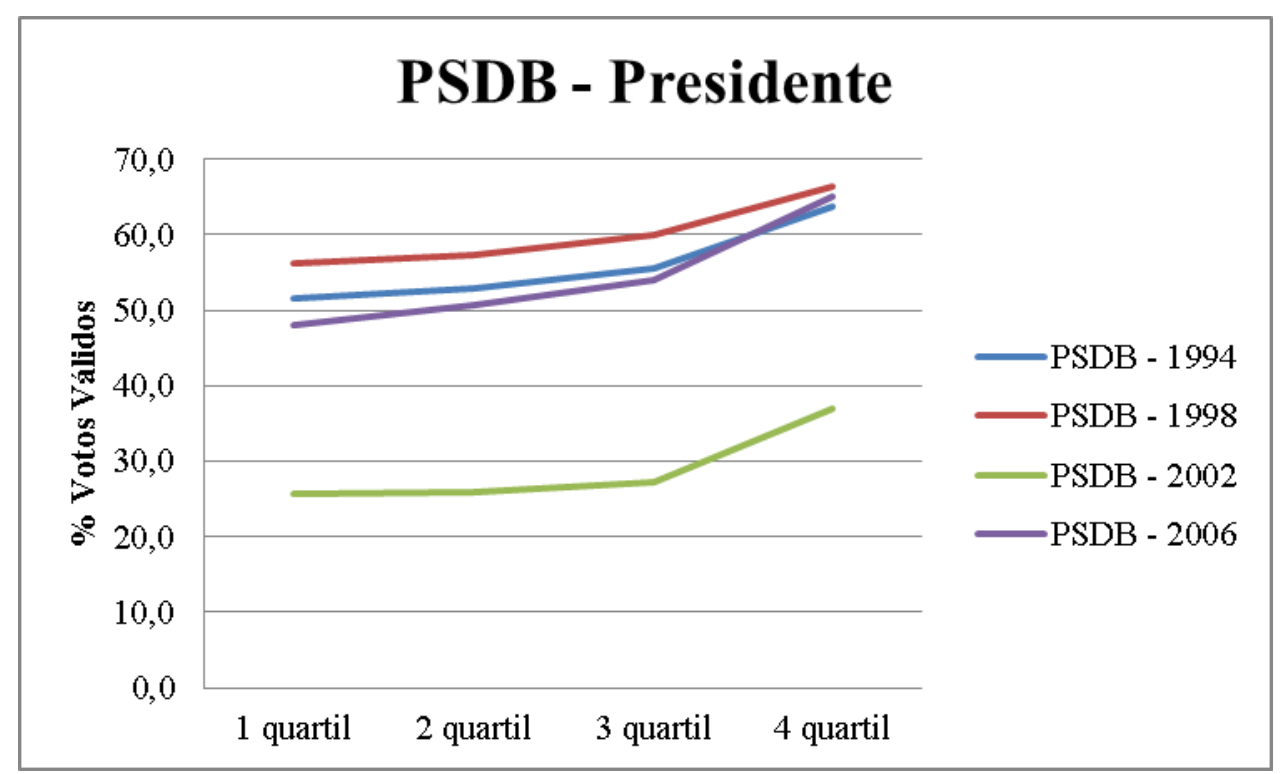

Tabela 12 - Regressão linear simples - PDSB / Educação - Presidente

\begin{tabular}{lcccc}
\hline \hline Ano/Informações do Modelo & 1994 & 1998 & 2002 & 2006 \\
\hline Coeficiente da V.I. & 6,701 & 5,536 & 6,866 & 9,433 \\
Erro-Padrão & 0,074 & 0,07 & 0,065 & 0,069 \\
Significância & $* * *$ & $* * *$ & $* * *$ & $* * *$ \\
R2 & 0,175 & 0,127 & 0,196 & 0,22 \\
$\mathrm{~N}$ & 38852 & 43527 & 46203 & 66281 \\
\hline \hline
\end{tabular}

Variável Dependente: \% Votos do PSDB

Variável Independente: Média de Educação

Unidade: Seção Eleitoral

Significância: $* * * \mathrm{p}<0,01$

Fonte: Banco de Dados Eleitorais CEM/CEBRAP 
Os resultados para o PSDB apontam em sentido semelhante ao do PT, só que em direção contrária e em menor força. O partido recebeu, em todo o período estudado, mais votos entre as urnas de maior educação. No entanto, esse padrão de apoio se manteve mais estável que o do PT entre as quatro eleições, e também não seguiu um aumento linear de inserção no seu grupo com o passar do tempo, como mostrado pelos betas da regressão, e pelas diferenças entre o primeiro e o último quartil: em 94, 12\%; em $98,10 \%$; em $02,11 \%$ e em $06,17 \%$.

Aqui também a disputa de 2006 resultou na maior correlação com a escolaridade por urna. Enquanto no nível nacional o PSDB atingiu 41\%, no último quartil do Estado de São Paulo, o mais educado, o partido atingiu $65 \%$.

Os resultados encontrados nesta seção mostram que PT e PSDB têm bases eleitorais definíveis em São Paulo, e as mudanças que ocorreram nos apoios dos diferentes níveis resultam em aprofundamento desse padrão.

\section{Síntese}

Em suma, o quadro partidário-eleitoral brasileiro, no que diz respeito à volatilidade das eleições presidenciais para o contexto paulista, apresenta razoável estabilidade. A constituição do índice é fortemente influenciada pelas estratégias dos partidos, ao decidirem pelo lançamento ou retirada de candidaturas, perfazendo o quadro de opções ofertadas ao eleitor. Isso significa que, em parte, a dominância e a prevalência de PSDB e PT na disputa presidencial é devida à coordenação intra-elites políticas, por meio de coligações com outros partidos relevantes ou pelo impedimento de que estes lancem candidatos. Por outro lado, pode-se dizer também que o eleitor mantém certa estabilidade em suas preferências, majoritariamente voltadas e orientadas para o pólo PT-PSDB. O fracasso das empreitadas de PMDB e PDT em 94, e deste em 06, e a força insuficiente de PPS e PSB em 02, revelam que mesmo quando PT e PSDB não são capazes de "fechar" inteiramente as opções dos eleitores via coordenação préeleitoral, retém parcela majoritária do eleitorado.

Além disso, a distribuição educacional da flutuação eleitoral, tanto no que se refere ao índice de Pedersen, quanto ao da volatilidade contrafactual, não permite afirmar que determinados grupos sociais têm sistematicamente comportamento mais volátil que outros. A votação dos partidos por educação levanta indícios de que parte da 
mudança de preferência dos menos educados está relacionada à inserção cada vez maior do PT entre esse grupo, ao passo que o PSDB sempre manteve patamar similar de maior apoio entre os de maior escolaridade. Isso revela que a bipolaridade eleitoral encontra lastro sócio-econômico nos eleitores. Em 2006, no entanto, os dados aqui levantados indicam que se aprofundou a polaridade social dos votos desses partidos. Portanto, tendo em vista o debate levantado por Singer (2009) sobre o realinhamento eleitoral das eleições presidenciais brasileiras em 2006, a análise levada a cabo por esta dissertação indica que no Estado de São Paulo PT e PSDB já eram ancorados em seções de menor e maior educação, respectivamente, desde 1994. Em 2006, entretanto, essa relação ficou mais forte: o exercício do governo pelo PT reforçou a tendência de correlação entre posição ideológica e nível social dos votantes nas eleições presidenciais em São Paulo. Um exercício futuro interessante pode ser análise semelhante produzida em outras unidades da federação.

\section{Eleições para governador de São Paulo 1982 - 2006}

Os pleitos para governador, de 1982 a 2006, atravessaram três grandes momentos político-partidários da história recente do Brasil: a transição e abertura dos anos 80, a eleição e queda do presidente Collor, e o período de bipolaridade da disputa nacional entre PT e PSDB construído nos anos 90. Assim, esse é um bom caso para verificar o impacto das mudanças nacionais, contextuais e de longo prazo na volatilidade para governador de estado.

$\mathrm{Na}$ tabela abaixo, encontram-se os índices de volatilidade de Pedersen, agregados ao nível estadual:

Tabela 13 - Volatilidade Eleitoral Pedersen - Governador - Nível do Estado de São Paulo - \%

\begin{tabular}{ccccccc}
\hline \hline $1982-1986$ & $1986-1990$ & $1990-1994$ & $1994-1998$ & $1998-2002$ & $2002-2006$ & Média \\
\hline 15,3 & 41,3 & 61,4 & 40,2 & 31,4 & 28 & 36,3 \\
\hline \hline
\end{tabular}

Fonte: Banco de dados Eleitorais CEM/CEBRAP

A tabela revela dados interessantes. A reorganização do quadro partidário e o período Collor parecem ter impactado fortemente a volatilidade em 86-90 e 90-94, os pares com valores de Pedersen mais elevados. Isso se reforça levando em consideração 
o pequeno índice de 82-86, no começo da abertura partidária, e a flutuação eleitoral menor em 98-02 e 02-06,

No entanto, abaixo veremos que o peso desses fatores de longo prazo incidiram mais sobre a estratégia partidária pontual de entrada e saída da competição que nas preferências expressas dos eleitores.

Como na análise da disputa presidencial, abaixo se encontra o cálculo do índice de volatilidade desagregado por urna e município, de 1994 a 2006, de modo a verificar um possível viés de impacto do nível de agregação na constituição do mesmo:

Tabela 14 - Volatilidade eleitoral - Governador - Nível das seções eleitorais - \%

\begin{tabular}{lcccc}
\hline \hline & $1994-1998$ & $1998-2002$ & $2002-2006$ & Média \\
\hline Média & 41,9 & 31,7 & 32,1 & 35,2 \\
Máximo & 85,9 & 85,4 & 68,6 & 80 \\
Mínimo & 12,4 & 6,8 & 3,8 & 7,6 \\
D.P. & 8,3 & 9,3 & 6,7 & 8,1 \\
Mediana & 41,9 & 30,9 & 32 & 34,9 \\
$\mathrm{~N}$ & 40994 & 43560 & 47307 & \\
\hline \hline
\end{tabular}

Fonte: Banco de dados Eleitorais CEM/CEBRAP

Tabela 15 - Volatilidade eleitoral - Governador - Nível dos municípios - \%

\begin{tabular}{lcccc}
\hline \hline & $1994-1998$ & $1998-2002$ & $2002-2006$ & Média \\
\hline Média & 45,7 & 37,3 & 30,5 & 37,8 \\
Máximo & 70,9 & 61,8 & 53,2 & 61,7 \\
Mínimo & 21,1 & 14,3 & 9,8 & 15 \\
D.P. & 8,3 & 7,7 & 7,4 & 7,8 \\
Mediana & 45,4 & 37,2 & 30,4 & 37,6 \\
$\mathrm{~N}$ & 625 & 645 & 645 & \\
\hline \hline
\end{tabular}

Fonte: Banco de dados Eleitorais CEM/CEBRAP

De modo geral, a média e a mediana dos três pares de eleição são semelhantes à volatilidade agregada em todo o Estado. Destacam-se como resultados levemente discrepantes os pares 94-98 e 98-02 no nível dos municípios. 


\section{Volatilidade Contrafactual}

No que diz respeito às entradas de partidos grandes e médios, a tabela abaixo revela que, no agregado, ela foi razoavelmente constante no tempo. Nada obstante, as decisões de apresentação do PDS-PP são chave para compreensão da dinâmica eleitoralpartidária em São Paulo, conforme veremos abaixo.

Quadro 8 - Eleições para Governador de SP - Candidaturas por Partidos Selecionados

\begin{tabular}{llllllll}
\hline \hline & 1982 & 1986 & 1990 & 1994 & 1998 & 2002 & 2006 \\
\hline PT & $\mathrm{X}$ & $\mathrm{X}$ & $\mathrm{X}$ & $\mathrm{X}$ & $\mathrm{X}$ & $\mathrm{X}$ & $\mathrm{X}$ \\
PDT & $\mathrm{X}$ & & & $\mathrm{X}$ & $\mathrm{X}$ & & $\mathrm{X}$ \\
PSB & & & & & & $\mathrm{X}$ & $\mathrm{X}$ \\
PCB/PPS & & & & & & & \\
PSDB & $\mathrm{X}$ & $\mathrm{X}$ & $\mathrm{X}$ & $\mathrm{X}$ & $\mathrm{X}$ & $\mathrm{X}$ & $\mathrm{X}$ \\
PMDB & $\mathrm{X}$ & $\mathrm{X}$ & & & & $\mathrm{X}$ & \\
PTB & & & & & & & \\
PL & & & & & & & \\
PFL/DEM & $\mathrm{X}$ & $\mathrm{X}$ & $\mathrm{X}$ & & $\mathrm{X}$ & $\mathrm{X}$ & \\
PDS/PP & 5 & 4 & 4 & 4 & 5 & 6 & 5 \\
\hline TOTAL & & & & & & & \\
\hline \hline
\end{tabular}

Fonte: TSE

Os valores da flutuação eleitoral hipotética, qual seja, supondo-se que os partidos são constantes na apresentação de candidaturas, ajudam a compreender quanto da volatilidade se deve às mudanças de preferências determinadas pelas decisões de entrada dos partidos.

A tabela abaixo apresenta os valores da volatilidade contrafactual, ou seja, as mudanças de voto apenas entre os partidos constantes em cada par considerado:

Tabela 16 - Cenário Contrafactual - Volatilidade Eleitoral - Governador - Nível do Estado de São Paulo \%

\begin{tabular}{|c|c|c|c|c|c|c|}
\hline 1982-1986 & 1986-1990 & 1990-1994 & 1994-1998 & $1998-2002$ & $2002-2006$ & Média \\
\hline 14 & 22,5 & 25,6 & 22,5 & 19,7 & 12,6 & 19,5 \\
\hline
\end{tabular}

Fonte: Banco de dados Eleitorais CEM/CEBRAP

Os resultados revelam que quase $50 \%$ da volatilidade captada pelo índice de Pedersen é causada necessariamente pela alteração da oferta partidária. Cada par de 
eleições apresentou sua especificidade: enquanto que em 82-86 quase toda a flutuação se dá entre os partidos "constantes", em 90-94 cerca de 60\% esteve determinada pelas mudanças no leque de escolhas do eleitor.

Se levarmos em consideração apenas os resultados do pós 94, a partir do par 9498, o índice de Pedersen apresenta média de 33,2\%, enquanto que a volatilidade contrafactual tem média de 18,2\%. Logo, tem-se que $45 \%$ da flutuação eleitoral é consequência necessária das decisões de entrada dos partidos, de 1994 a 2006.

Para uma compreensão acurada da manutenção/flutuação do voto, faz-se necessário levar em consideração a atuação eleitoral do PP. O partido disputou cinco das sete eleições consideradas, não elegeu nenhum governador, mas por duas vezes atingiu a primeira posição no primeiro turno: em 1990 e 1998 (na primeira ocasião, sofreu a virada no segundo turno do PMDB; na segunda ocasião, do PSDB). O ponto a ser ressaltado consiste nas eleições consecutivas aos referidos pleitos. Em 1994, devido a decisões estratégicas internas, o partido não participa da competição estadual. Esse fato impossibilitou seus eleitores do pleito anterior de manterem sua preferência partidária eleitoral. O impacto foi tão grande que consistiu em $35 \%$ do índice de volatilidade de Pedersen em 90-94, e em 76\% da flutuação contrafactual. Já em 2002, fica patente o naufrágio eleitoral enfrentado pelo partido notadamente após o exercício da prefeitura paulistana em 97-00. Logo, observa-se mudança de preferência eleitoral, que culminará na ausência de candidatura do PP em 2006.

Em síntese, tanto a volatilidade constituída por decisões partidárias de entrada na competição quanto a flutuação fruto de mudança da direção do voto encontram no PPB/PP seu principal exemplo, no caso da eleição para governador do Estado de São Paulo.

Ao levarmos em consideração a contextualização histórico-político empreendida no início dessa seção, veremos que os índices de volatilidade não se alteraram muito entre os períodos de consolidação democrática no Brasil. Tão importante quanto esses fatores de longo prazo são as decisões estratégicas dos partidos pontuais de cada pleito. Evidentemente, a observação dos resultados eleitorais é suficiente para verificar que os períodos históricos estão associados com quedas e subidas de determinados partidos: por exemplo, a decadência do PMDB no começo dos anos 90, e a subida do PT nos 2000. Entretanto, o que é importante sublinhar é que o quadro partidário revela uma 
movimentação do eleitorado razoavelmente constante no tempo, fortemente impactado pelas decisões partidárias.

\section{Volatilidade governador por educação}

Para analisar a relação entre escolaridade e flutuação eleitoral, foram utilizados os mesmos procedimentos das disputas para presidente. Abaixo se encontram as tabelas, por quartil educacional e o modelo de regressão (com dados pós 94):

Tabela 17 -Volatilidade eleitoral - Governador - Quartis educacionais $\%$

\begin{tabular}{lrrr}
\hline \hline Ano/quartil & $1994-1998$ & $1998-2002$ & $2002-2006$ \\
\hline 1 quartil & 39,2 & 36,4 & 27,3 \\
2 quartil & 40,2 & 34,3 & 27,2 \\
3 quartil & 41,5 & 30,6 & 30,2 \\
4 quartil & 40,3 & 23 & 34,2 \\
\hline \hline
\end{tabular}

Fonte: Banco de Dados Eleitorais CEM/CEBRAP

Tabela 18 - Regressão Linear simples - Volatilidade Eleitoral Pedersen / Educação - Governador

\begin{tabular}{lccc}
\hline \hline Ano/Informações do Modelo & $1994-1998$ & $1998-2002$ & $2002-2006$ \\
\hline Coeficiente da V.I. & $-1,421$ & $-7,978$ & 2,276 \\
Erro-Padrão & 0,057 & 0,049 & 0,042 \\
Significância & $* * *$ & $* * *$ & $* * *$ \\
$\mathrm{R} 2$ & 0,015 & 0,379 & 0,057 \\
$\mathrm{~N}$ & 39950 & 43526 & 47307 \\
\hline \hline
\end{tabular}

Variável Dependente: Volatilidade Eleitoral de Pedersen

Variável Independente: Média de Educação

Unidade: Seção Eleitoral

Significância: *** $\mathrm{p}<0,01$

Fonte: Banco de Dados Eleitorais CEM/CEBRAP

Os dados mostram uma relação entre volatilidade e educação semelhante ao das eleições presidenciais: os dois primeiros pares com associações negativas, e o último correlacionado positivamente. Cabe notar aqui a alta magnitude do coeficiente negativo em 98-02. Os resultados por quartis educacionais mostram que esse par foi o que apresentou maior diferença entre o primeiro, de menor educação, e o último, o de maior. 
Abaixo se encontram os mesmos exercícios, mas com o índice de volatilidade contrafactual:

Tabela 19 - Cenário Contrafactual -Volatilidade eleitoral - Governador Quartis educacionais \%

\begin{tabular}{lrrc}
\hline \hline Ano/quartil & $1994-1998$ & $1998-2002$ & $2002-2006$ \\
\hline 1 quartil & 21,9 & 22,2 & 12,4 \\
2 quartil & 22,6 & 21 & 12 \\
3 quartil & 23,2 & 19 & 14,5 \\
4 quartil & 22,3 & 15,3 & 18,5 \\
\hline \hline
\end{tabular}

Fonte: Banco de Dados Eleitorais CEM/CEBRAP

Tabela 20 - Regressão Linear simples - Cenário Contrafactual / Educação Governador

\begin{tabular}{lccc}
\hline \hline Ano/Informações do Modelo & $1994-1998$ & $1998-2002$ & $2002-2006$ \\
\hline Coeficiente da V.I. & $-1,399$ & $-4,428$ & 0,943 \\
Erro-Padrão & 0,036 & 0,044 & 0,032 \\
Significância & $* * *$ & $* * *$ & $* * *$ \\
R2 & 0,035 & 0,185 & 0,017 \\
$\mathrm{~N}$ & 39950 & 43526 & 47307 \\
\hline \hline
\end{tabular}

Variável Dependente: Volatilidade Eleitoral Contrafactual

Variável Independente: Média de Educação

Unidade: Seção Eleitoral

Significância: $* * * \mathrm{p}<0,01$

Fonte: Banco de Dados Eleitorais CEM/CEBRAP

A distribuição educacional da volatilidade contrafactual, ou seja, apenas entre os partidos constantes, revela uma diminuição do peso da variação da educação na variação da flutuação eleitoral. No entanto, fica o destaque para os pleitos de 19982002: a cada aumento de uma unidade de escolaridade na média da urna, aumenta-se em $-4,4$ o valor predito da flutuação eleitoral entre os partidos constantes. Os resultados eleitorais ordenados por educação média da seção, conforme mostraremos nos gráficos abaixo, mostram que tanto PT quanto PSDB aumentaram sua inserção entre as urnas das mais baixas posições. 


\section{Votos por educação}

Ao longo de 94-06, três partidos se destacaram nas eleições para governador de São Paulo: PSDB, PP e PT; cabe um representante de um ponto no espectro ideológico. O objetivo dessa seção é verificar se esses partidos obtiveram maior inserção em grupos educacionais diferentes, se isso se manteve no tempo, e se esse padrão tem relação com a divisão ideológica que os analistas políticos freqüentemente a eles atribuem.

Novamente, as técnicas adotadas são as mesmas da análise das eleições para presidente, expostas acima. Inicialmente, os resultados sobre o apoio do PT:

\section{Gráfico 3}

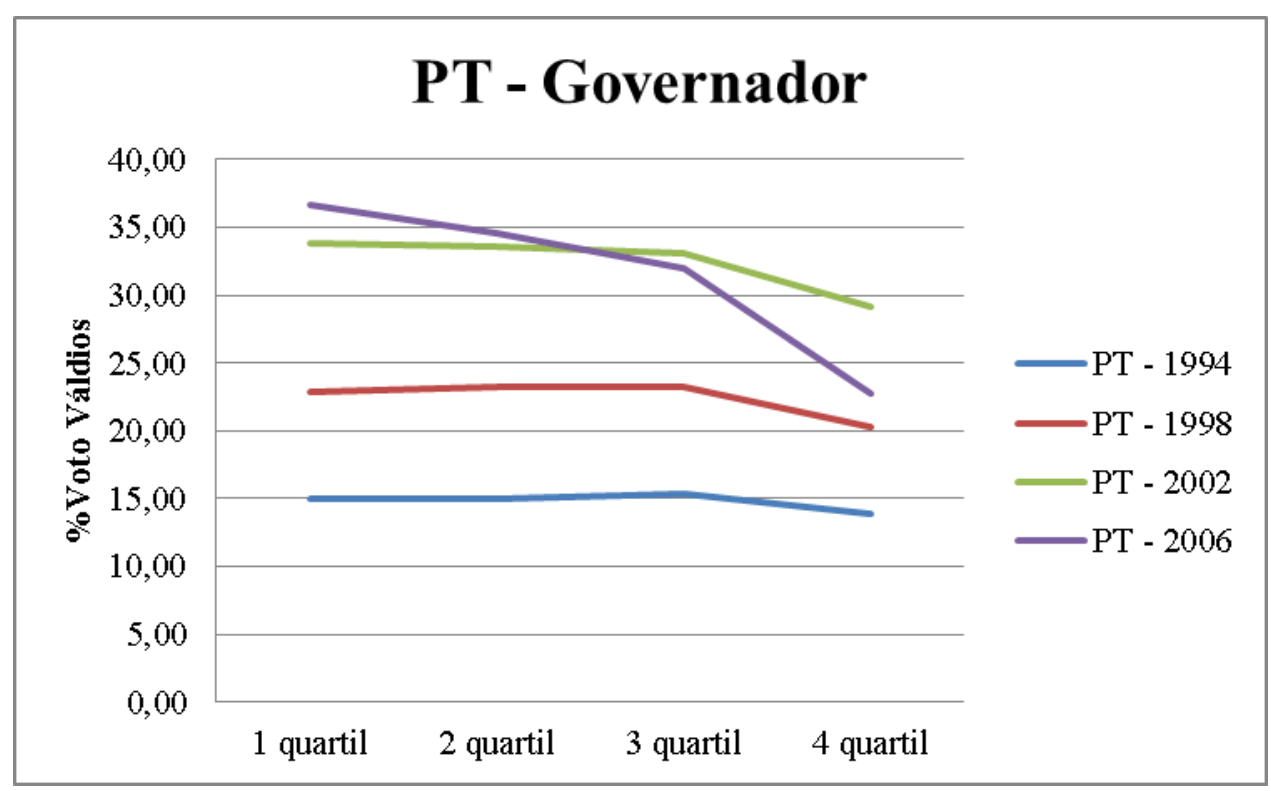

Tabela 21 - Regressão linear simples - PT / Educação - Governador

\begin{tabular}{lcccc}
\hline \hline Ano/Informações do Modelo & 1994 & 1998 & 2002 & 2006 \\
\hline Coeficiente da V.I. & $-0,444$ & $-1,206$ & $-2,584$ & $-7,547$ \\
Erro-Padrão & 0,054 & 0,056 & 0,06 & 0,064 \\
Significância & $* * *$ & $* * *$ & $* * *$ & $* * *$ \\
$\mathrm{R} 2$ & 0,002 & 0,01 & 0,038 & 0,17 \\
$\mathrm{~N}$ & 38852 & 43527 & 46203 & 66281 \\
\hline \hline
\end{tabular}

Variável Dependente: \% Votos do PT

Variável Independente: Média de Educação

Unidade: Seção Eleitoral

Significância: *** $\mathrm{p}<0,01$

Fonte: Banco de Dados Eleitorais CEM/CEBRAP 
Os dados mostram que o partido sempre foi mais sufragado entre as seções de menor educação. Mais do que isso, essa relação fica mais forte com o passar das disputas, atingindo coeficiente de $-7,5$ no modelo de regressão em 2006. Cabe notar o cruzamento das retas de 2002 e 2006: na comparação entre esses dois anos, embora a votação no agregado tenha sido semelhante, - 32\% -, em 2006 o partido foi mais votado nos dois primeiros quartis, os de menor escolaridade, enquanto que em 2002 recebeu mais apoio nos dois últimos grupos, os de maior escolaridade. A flutuação dos últimos grupos foi mais acentuada que a dos primeiros, configurando um cenário nas eleições estaduais paulista semelhante ao que ocorreu nos pleitos presidenciais tanto ao nível nacional, quanto ao nível estadual, como vimos acima.

Agora, passemos para os dados referentes à votação do PSDB:

\section{Gráfico 4}

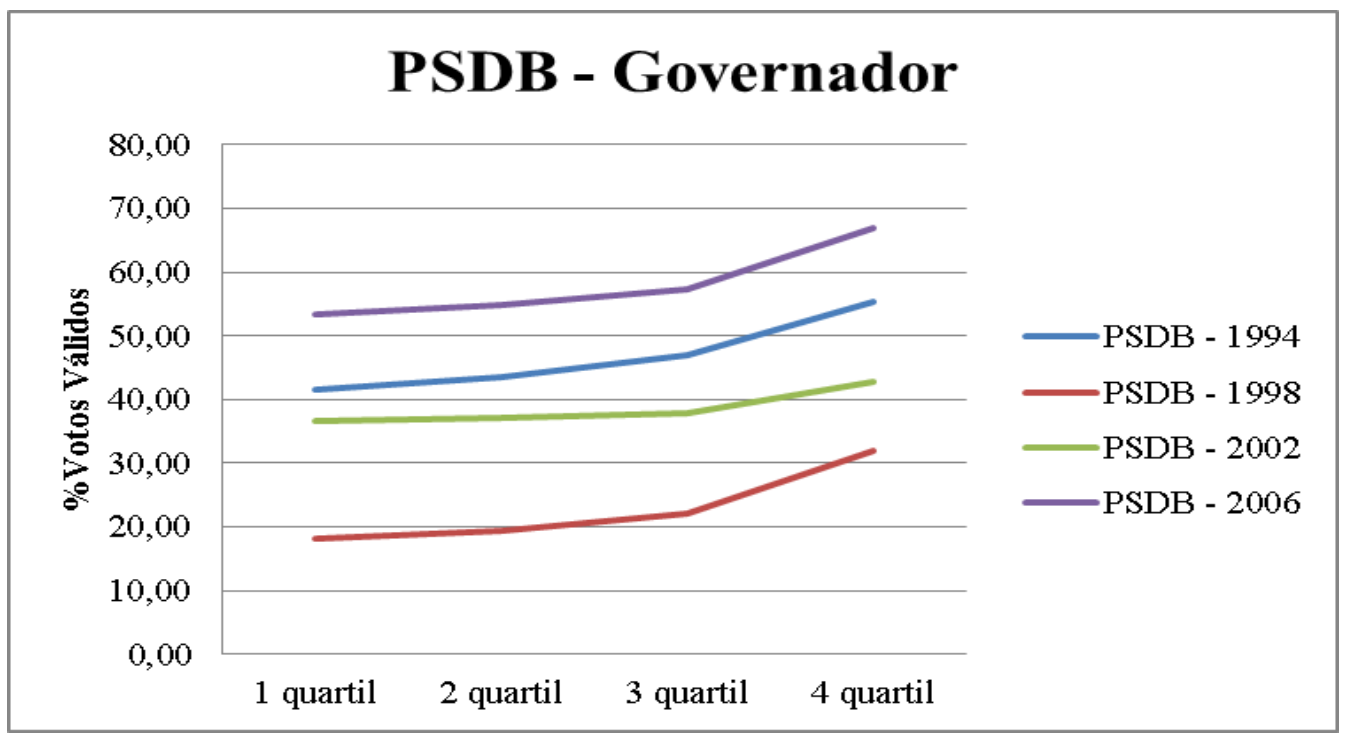

Tabela 22 - Regressão linear simples - PSDB / Educação - Governador

\begin{tabular}{lcccc}
\hline \hline Ano/Informações do Modelo & 1994 & 1998 & 2002 & 2006 \\
\hline Coeficiente da V.I. & 7,431 & 8,126 & 3,612 & 7,545 \\
Erro-Padrão & 0,069 & 0,051 & 0,058 & 0,073 \\
Significância & $* * *$ & $* * *$ & $* * *$ & $* * *$ \\
R2 & 0,23 & 0,369 & 0,078 & 0,136 \\
$\mathrm{~N}$ & 38852 & 43527 & 46203 & 66281 \\
\hline \hline
\end{tabular}

Variável Dependente: \% Votos do PSDB

Variável Independente: Média de Educação

Unidade: Seção Eleitoral

Significância: $* * * \mathrm{p}<0,01$

Fonte: Banco de Dados Eleitorais CEM/CEBRAP 
Os resultados do PSDB sinalizam que a base de apoio desse partido são as seções com maior escolaridade. À exceção de 2002, os coeficientes da regressão linear simples sempre atingiram valores acima de sete, indicando que cada aumento de uma unidade na escolaridade média por urna, aumenta-se em sete pontos percentuais o valor predito da votação do partido.

Por último, dados sobre o desempenho do $\mathrm{PP}(\mathrm{B})$, que conseguiu boas votações em 98 e 02:

\section{Gráfico 5}

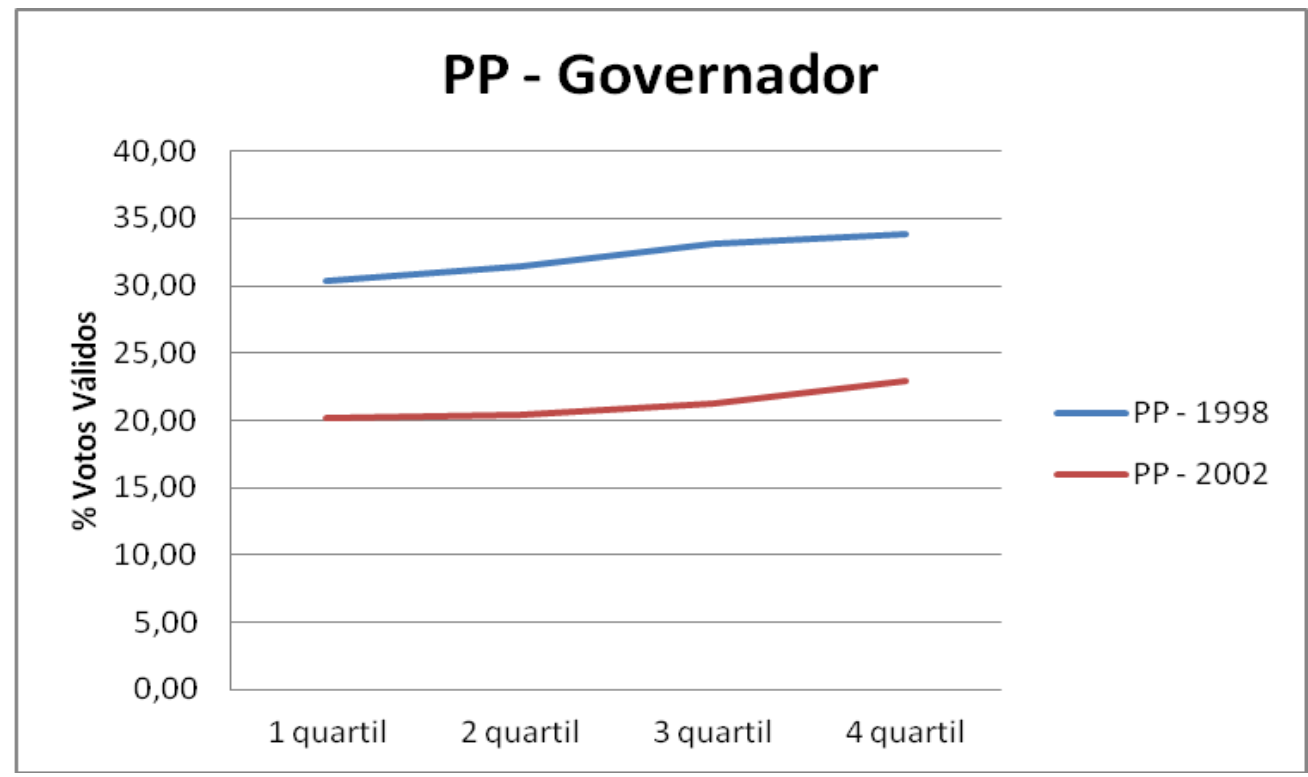

Tabela 23 - Regressão linear simples - PP / Educação - Governador

\begin{tabular}{lcc}
\hline \hline Ano/Informações do Modelo & 1998 & 2002 \\
\hline Coeficiente da V.I. & 1,019 & 1,314 \\
Erro-Padrão & 0,057 & 0,043 \\
Significância & $* * *$ & $* * *$ \\
$\mathrm{R} 2$ & 0,007 & 0,02 \\
$\mathrm{~N}$ & 43527 & 46203 \\
\hline \hline
\end{tabular}

Variável Dependente: \% Votos do PP

Variável Independente: Média de Educação

Unidade: Seção Eleitoral

Significância: $* * * \mathrm{p}<0,01$

Fonte: Banco de Dados Eleitorais CEM/CEBRAP 
Os resultados mostram que o partido foi mais votado conforme era maior a escolaridade. Apesar da pequena força dessa relação, ela foi contínua conforme se passa do primeiro para o quarto quartil.

Em síntese, os resultados do desempenho eleitoral por educação dos três maiores competidores para o governo estadual de São Paulo de 1994 a 2006 levanta indícios de que eles possuem tipos de eleitores partidários: o PT com os de menor escolaridade, o PSDB com os de maior, e o PP com leve inclinação para os mais educados.

\section{Síntese}

Nesta seção, pode-se observar que o quadro eleitoral-partidário paulista, que à primeira vista parecia instável, apresenta razoável coerência e estrutura. Os movimentos dos eleitores respeitam limites espaciais, e a volatilidade é fortemente determinada pela oferta de candidaturas e por coordenação estratégica dos eleitores.

A bipolarização crescente em torno de PSDB-PT deu-se por meio da erosão do PP-PDS-PPB e da perda da força eleitoral do PDT nos anos 90. Retornando o raciocínio histórico para o período 82-90, o que fica patente é outra queda eleitoral, agora do PMDB, fruto da perda de hegemonia dessa legenda com o governo federal de Sarney e o estadual de Quércia, culminando na fundação do PSDB e na abertura de um nicho eleitoral para o PT entre a população de classe mais baixa, que com o passar dos anos foi aprofundando sua inserção nessa camada da sociedade. Dessa forma, o padrão educacional deste partido não apresentou a mesma nitidez das disputas presidenciais no mesmo período. Enquanto o PSDB sempre obteve mais sufrágio entre as urnas de maior educação, o PT enfrentava forte competição na busca pelo eleitor de menor posição na escala social em 94 e 98, entre PMDB e PDT. Esses achados indicam que avaliações sobre a inserção eleitoral dos partidos em grupos sociais específicos deve levar em consideração a dinâmica temporal da competição, ou mais diretamente, a força e o padrão eleitoral pretérito de outras legendas.

Mais uma vez, assim como na eleição presidencial, a proeminência de PT e PSDB no tempo é fruto tanto das estratégias pré-eleitorais, na configuração das opções oferecidas ao eleitor, quanto das preferências deste, que os escolhe em detrimento de outras forças políticas. No caso da eleição pra governador, isso é ainda mais claro, visto que outros partidos nacionalmente grandes e médios não se furtaram a disputar esse 
pleito. Focando apenas no pós-94, tem-se o PDT que compete em 2006, o PSB disputa neste ano e em 2002 e o PMDB participa de todas as disputas analisadas, de 94 a 06. Afora o fato de que os candidatos apresentados, muitas vezes, serem de pouca expressão política, o que podemos observar é que aqui também, como na eleição presidencial, PSDB e PT foram capazes de manter e mobilizar um eleitorado constante, que lhes permitiu vantagem na competição eleitoral.

\section{Presidente e Governador por município}

O objetivo desta seção é discutir brevemente os resultados de volatilidade de Pedersen e volatilidade contrafactual das eleições para presidente e governador por tamanho de município. Para tanto, ordenei os pares de eleição, 1994-1998, 1998-2002 e 2002-2006, por ordem crescente de número de votos válidos no T2 (ou seja, 98, 02 e 06, respectivamente) e separei em quartis. Depois calculei ambos os tipos de volatilidade dentre desses quartis. O objetivo é verificar se existe uma tendência de maior ou menor flutuação eleitoral conforme os diferentes tipos demográficos de município.

Inicialmente, vejamos os dados para as eleições presidenciais:

Tabela 24 -Volatilidade eleitoral - Presidente - Nível dos Municípios de São Paulo - Quartis de tamanho - \%

\begin{tabular}{lccc}
\hline \hline Ano/No Votos Válidos & $1994-1998$ & $1998-2002$ & $2002-2006$ \\
\hline 1 quartil & 20,4 & 34,3 & 24,3 \\
2 quartil & 18,3 & 34,1 & 29,2 \\
3 quartil & 16,5 & 34,6 & 31,7 \\
4 quartil & 19,4 & 35,1 & 35,4 \\
\hline \hline
\end{tabular}

Fonte: Banco de Dados Eleitorais CEM/CEBRAP 
Tabela 25 -Cenário Contrafactual - Volatilidade eleitoral -

Presidente - Nível dos Municípios de São Paulo - Quartis de tamanho - \%

\begin{tabular}{lccc}
\hline \hline Ano/No Votos Válidos & $1994-1998$ & $1998-2002$ & $2002-2006$ \\
\hline 1 quartil & 6,4 & 26,6 & 12,4 \\
2 quartil & 5,4 & 26 & 16,1 \\
3 quartil & 5,1 & 25,8 & 17,7 \\
4 quartil & 9,1 & 26,1 & 17,6 \\
\hline \hline
\end{tabular}

Fonte: Banco de Dados Eleitorais CEM/CEBRAP

Os dados mostram que não existe uma tendência inequívoca de maior mudança da direção partidária do voto conforme o tamanho da cidade. Destaca-se uma leve tendência do último quartil, o das maiores cidades, em apresentar os maiores índices de volatilidade total.

Agora, os resultados para governador:

Tabela 26 -Volatilidade eleitoral - Governador - Nível dos Municípios de São Paulo - Quartis de tamanho - \%

\begin{tabular}{lccc}
\hline \hline Ano/No Votos Válidos & $1994-1998$ & $1998-2002$ & $2002-2006$ \\
\hline 1 quartil & 43,5 & 37,4 & 25,3 \\
2 quartil & 45,3 & 38,2 & 28,8 \\
3 quartil & 44,3 & 38,7 & 29,9 \\
4 quartil & 39,7 & 30,5 & 27,8 \\
\hline \hline
\end{tabular}

Fonte: Banco de Dados Eleitorais CEM/CEBRAP

Tabela 27 -Cenário Contrafactual - Volatilidade eleitoral Governador - Nível dos Municípios de São Paulo - Quartis de tamanho - \%

\begin{tabular}{lccc}
\hline \hline Ano/No Votos Válidos & $1994-1998$ & $1998-2002$ & $2002-2006$ \\
\hline 1 quartil & 22,9 & 27,9 & 12,6 \\
2 quartil & 24,7 & 28,6 & 15 \\
3 quartil & 24,1 & 28 & 16,3 \\
4 quartil & 22,4 & 18,5 & 13,5 \\
\hline \hline
\end{tabular}

Fonte: Banco de Dados Eleitorais CEM/CEBRAP

Os índices de volatilidade Pedersen e de volatilidade contrafactual nas eleições para governador estratificados por tamanho de município novamente não assinalam um viés por tipo de município. Aqui, os quartis tendem a se tornar mais homogêneos na volatilidade do cenário hipotético, contrafactual. 
Em síntese, os dados mostram que não se pode fazer nenhuma imputação quanto a características das cidades e maior ou menor volatilidade. A visão segundo a qual localidades menos desenvolvidas teriam maior propensão seja ao comportamento errático, efeito da incapacidade cognitiva de seus habitantes em manter uma coerência do mundo político, seja ao comportamento estável, fruto da situação "clientelista" que poderiam se encontrar, não encontra apoio nesses dados.

\section{Comparação governador presidente}

Para finalizar as análises da eleição nacional e estadual, realizo uma rápida comparação entre os índices de flutuação do voto entre esses pleitos nos mesmos pares de eleição, agregados ao nível estadual. O objetivo é mostrar que o mesmo eleitorado, durante os mesmos períodos eleitorais, apresenta volatilidade diferente quando se controla pela alteração do quadro partidário. Para tanto, reproduzo as tabelas 3, 13, 6 e 16 apresentadas anteriormente.

Tabela 3 -Volatilidade eleitoral Pedersen - Presidente - Nível do Estado de São Paulo - \%

\begin{tabular}{ccccc}
\hline \hline $1989-1994$ & $1994-1998$ & $1998-2002$ & $2002-2006$ & Média \\
\hline 55 & 14,7 & 35 & 34,7 & 34,8 \\
\hline \hline
\end{tabular}

Fonte: Banco de dados Eleitorais CEM/CEBRAP

Tabela 13 - Volatilidade Eleitoral Pedersen - Governador - Nível do Estado de São Paulo - \%

\begin{tabular}{ccccccc}
\hline \hline $1982-1986$ & $1986-1990$ & $1990-1994$ & $1994-1998$ & $1998-2002$ & $2002-2006$ & Média \\
\hline 15,3 & 41,3 & 61,4 & 40,2 & 31,4 & 28 & 36,3 \\
\hline \hline
\end{tabular}

Fonte: Banco de dados Eleitorais CEM/CEBRAP

A comparação se dá entre os quatro pares do pleito presidencial com os quatro últimos do estadual. Pode-se observar uma certa semelhança entre os índices de volatilidade eleitoral, tanto no que diz respeito à magnitude, à exceção de 94-98, quanto à tendência constante de queda.

No entanto, os índices de volatilidade contrafactual, reapresentados abaixo, revelam outro cenário: 
Tabela 6 - Cenário Contrafactual -Volatilidade eleitoral - Presidente - Nível do Estado de São Paulo - \%

\begin{tabular}{ccccc}
\hline \hline $1989-1994$ & $1994-1998$ & $1998-2002$ & $2002-2006$ & Média \\
\hline 51 & 6,3 & 26,1 & 17,5 & 25,6 \\
\hline \hline
\end{tabular}

Fonte: Banco de dados Eleitorais CEM/CEBRAP

Tabela 16 - Cenário Contrafactual - Volatilidade Eleitoral - Governador - Nível do Estado de São Paulo \%

\begin{tabular}{ccccccc}
\hline \hline $1982-1986$ & $1986-1990$ & $1990-1994$ & $1994-1998$ & $1998-2002$ & $2002-2006$ & Média \\
\hline 14 & 22,5 & 25,6 & 22,5 & 19,7 & 12,6 & 19,5 \\
\hline \hline
\end{tabular}

Fonte: Banco de dados Eleitorais CEM/CEBRAP

Tanto a magnitude da flutuação do voto nos pares correspondentes quanto a tendência de queda não são similares entre os cenários contrafactuais da volatilidade para presidente e governador. A primeira apresenta índices mais elevados, à exceção novamente do par 94-98, e não apresenta tendência linear de queda.

Em suma, para uma interpretação acurada do índice de volatilidade de Pedersen faz-se necessário levar em consideração as decisões de entrada dos partidos, e não apenas as relações de identidade entre partido e eleitor.

\section{Eleições para prefeito de São Paulo 1985-2008}

Desde a primeira eleição direta para prefeito de São Paulo pós ditadura militar, em, 1985, até 2008, cinco partidos diferentes ganharam as quatro eleições para a prefeitura de São Paulo, de todos os matizes ideológicos. Essa afirmação parece indicar uma instabilidade eleitoral crônica do eleitor paulistano. $\mathrm{O}$ objetivo aqui é traçar um quadro analítico mais acurado, que permita visualizar até que ponto essa indicação corresponde à realidade ou se, antes, a flutuação do resultado eleitoral para as eleições municipais de São Paulo deve-se mais às mudanças nas opções partidárias definidas pelas elites políticas aos eleitores do que propriamente às oscilações das preferências expressas no voto. 
Abaixo se encontra a tabela 25 com o índice de volatilidade de Pedersen para prefeito de São Paulo:

Tabela 28 - Volatilidade Eleitoral Pedersen - Prefeito - Nível da Cidade de São Paulo \%

\begin{tabular}{ccccccc}
\hline \hline $1985-1988$ & $1988-1992$ & $1992-1996$ & $1996-2000$ & $2000-2004$ & $2004-2008$ & Média \\
\hline 59,6 & 17,3 & 18,4 & 41,8 & 30 & 38,7 & 34,3 \\
\hline \hline
\end{tabular}

Fonte: Banco de dados Eleitorais CEM/CEBRAP

A média da volatilidade para prefeito de São Paulo é semelhante aos resultados das eleições presidenciais e de governador: $34,3 \%$. Cabe notar o alto índice do primeiro par, quando do fim do período da redemocratização, e o baixo valor em 92-96, quando início da construção da bipolaridade nacional entre PT e PSDB.

A tabela 26 mostra estatísticas descritivas da volatilidade calculada ao nível das seções eleitorais:

Tabela 29 - Volatilidade eleitoral - Prefeito - Nível das seções eleitorais -

\begin{tabular}{lcccc}
\multicolumn{5}{c}{$\%$} \\
\hline \hline Média & 42,4 & 33 & 40,8 & 38,7 \\
Máximo & 81,4 & 55,5 & 67,7 & 68,2 \\
Mínimo & 26,3 & 12,3 & 7,6 & 15,4 \\
D.P. & 4,2 & 4,4 & 9,2 & 5,9 \\
Mediana & 42,4 & 32,9 & 41,5 & 38,9 \\
$\mathrm{~N}$ & 13128 & 13769 & 16970 & \\
\hline \hline
\end{tabular}

Assim como nos dois níveis anteriores (eleição presidencial e para governador), os resultados médios e medianos da volatilidade calculada no nível mais desagregado possível pouco diferem do índice composto pelo nível municipal, o mais agregado no caso ora em tela.

A variação no quadro de candidaturas apresentadas foi grande. Abaixo se encontra o quadro 8 com os partidos participantes de 85 a 08 : 
Quadro 9 - Eleições Prefeito de São Paulo - Partidos Participantes

\begin{tabular}{|c|c|c|c|c|c|c|c|}
\hline & 1985 & 1988 & 1992 & 1996 & 2000 & 2004 & 2008 \\
\hline $\mathrm{PT}$ & $X$ & $X$ & $X$ & $X$ & $X$ & $X$ & $X$ \\
\hline PDT & & $X$ & & $X$ & & $X$ & \\
\hline PSB & $X$ & & & & $X$ & $X$ & \\
\hline PCB/PPS & & & & & & & $X$ \\
\hline PSDB & & $X$ & $X$ & $X$ & $X$ & $X$ & $X$ \\
\hline PMDB & $X$ & $X$ & $X$ & $X$ & & & \\
\hline PL & $X$ & $X$ & & & $X$ & & \\
\hline РTB & $X$ & $X$ & & $X$ & & & \\
\hline PFL/DEM & & & & & $X$ & & $X$ \\
\hline PDS/PP & & $X$ & $X$ & $X$ & $X$ & $X$ & $X$ \\
\hline SOMA & 5 & 7 & 4 & 6 & 6 & 5 & 5 \\
\hline
\end{tabular}

Fonte: TSE

O cenário das candidaturas apresentadas na disputa municipal paulistana mostra, à primeira vista, um quadro de pouca pré-coordenação eleitoral, de acordo com o conceito formulado por Cox (1997): partidos médios e grandes, algumas vezes possíveis aliados, não se furtaram a lançar candidaturas próprias no decorrer das disputas, não "fechando" as opções de escolha para o eleitor. Pode-se pensar em duas explicações para esse fenômeno: de um lado, a possibilidade aberta pela derrocada eleitoral do PP, na segunda metade dos anos 90; de outro, uma possível coordenação federativa intertemporal: como os pleitos municipais ocorrem na metade das disputas estaduais e nacionais, cria-se mais uma instância submetida ao jogo de coordenação entre os partidos: de um lado, acordos de apoio nas eleições majoritárias de dois anos seguintes, de outro uma tentativa de partidos médios busquem criar ou manter visibilidade eleitoral, almejando melhores desempenhos nos pleitos legislativos posteriores.

Entretanto, ao se observar o quadro acima, o que pode ser notado é que três partidos se destacam na apresentação recorrente de candidaturas: PT, PSDB e PP. Logo, a despeito do jogo de candidaturas, não é coincidência que essas legendas mantêm a proeminência na competição municipal paulistana.

Fazendo o cálculo da volatilidade contrafactual, cujos valores estão expostos na tabela abaixo, observa-se que cerca de $40 \%$ do índice de Pedersen, exposto na tabela 25 , se deve à movimentação dos partidos, impossibilitando o eleitor de repetir sua preferência. 
Tabela 30 - Cenário Contrafactual - Volatilidade Eleitoral - Prefeito - Nível da Cidade de São Paulo \%

\begin{tabular}{ccccccc}
\hline \hline $1985-1988$ & $1988-1992$ & $1992-1996$ & $1996-2000$ & $2000-2004$ & $2004-2008$ & Média \\
\hline 37,7 & 14 & 14,6 & 23,4 & 21,5 & 15,1 & 21 \\
\hline \hline \multicolumn{7}{c}{ Fonte: Banco de dados Eleitorais CEM/CEBRAP }
\end{tabular}

A comparação entre este cenário de volatilidade contrafactual e o índice total de Pedersen exposto acima revela especificidades de cada par de eleição: por exemplo, a pequena queda em 1988-1992 e 2000-2004, mostrando que nessas ocasiões a maior parte da mudança de votos se deu entre partidos constantes no par de disputas; e a grande diferença no último par, 2004-2008, revelando o peso da candidatura emergente do DEM.

Se se considerar apenas o período pós 96, os partidos flutuantes são responsáveis por $45 \%$ da volatilidade.

Abaixo se encontra a relação entre os dados de flutuação do voto e a educação média por seção eleitoral.

Tabela 31 - Volatilidade eleitoral - Prefeito - Quartis educacionais - \%

\begin{tabular}{lccc}
\hline \hline Ano/quartil & $1996-2000$ & $2000-2004$ & $2004-2008$ \\
\hline 1 quartil & 40,5 & 30,5 & 30,2 \\
2 quartil & 42,2 & 30,6 & 35,5 \\
3 quartil & 42,9 & 34 & 42,3 \\
4 quartil & 41,1 & 32,5 & 50 \\
\hline \hline
\end{tabular}

Fonte: Banco de Dados Eleitorais CEM/CEBRAP

Tabela 32 - Regressão Linear simples - Volatildade Eleitoral Pedersen / Educação - Prefeito

\begin{tabular}{lccc}
\hline \hline & $1996-2000$ & $2000-2004$ & $2004-2008$ \\
\hline Coeficiente da V.I. & $-0,353$ & $-0,06$ & 8,835 \\
Erro-Padrão & 0,047 & 0,049 & 0,065 \\
Significância & $* * *$ & $* * *$ & $* * *$ \\
$\mathrm{R} 2$ & 0,004 & 0 & 0,521 \\
$\mathrm{~N}$ & 13094 & 13735 & 16970 \\
\hline \hline
\end{tabular}

Variável Dependente: \% Volatilidade Eleitoral

Variável Independente: Média de Educação

Unidade: Seção Eleitoral

Significância: $* * * \mathrm{p}<0,01$

Fonte: Banco de Dados Eleitorais CEM/CEBRAP 
A distribuição educacional do índice de volatilidade para prefeito da capital mostra um padrão diferente do observado nos pleitos para presidente e governador. Aqui, os pares 96-00 e 00-04, que estão associados com baixa educação, apresentam impacto muito baixo, enquanto que em 04-08 a mudança de voto esteve fortemente relacionada a seções de alta escolaridade.

Esse mesmo exercício realizado para o cenário contrafactual, retirando os partidos que não participaram de duas eleições seguidas, revela que as seções de maior educação são as mais alteraram sua preferência eleitoral entre os partidos constantes, a ponto de inverter o sinal do coeficiente em 96-00 e 00-04.

Tabela 33 - Cenário Contrafactual - Volatilidade Eleitoral - Prefeito Quartis educacionais - \%

\begin{tabular}{lrrr}
\hline \hline Ano/quartis & $1996-2000$ & $2000-2004$ & $2004-2008$ \\
\hline 1 quartil & 18,3 & 21,6 & 10,1 \\
2 quartil & 22,2 & 21,5 & 13 \\
3 quartil & 25,2 & 25,2 & 16,9 \\
4 quartil & 27,8 & 25,6 & 21,7 \\
\hline \hline
\end{tabular}

Fonte: Banco de Dados Eleitorais CEM/CEBRAP

Tabela 34 - Regressão Linear simples - Cenário Contrafactual / Educação - Prefeito

\begin{tabular}{lccc}
\hline \hline & $1996-2000$ & $2000-2004$ & $2004-2008$ \\
\hline Coeficiente da V.I. & 4,01 & 1,034 & 4,659 \\
Erro-Padrão & 0,044 & 0,044 & 0,033 \\
Significância & $* * *$ & $* * *$ & $* * *$ \\
$\mathrm{R} 2$ & 0,383 & 0,037 & 0,542 \\
$\mathrm{~N}$ & 13094 & 13735 & 16970 \\
\hline \hline
\end{tabular}

Variável Dependente: Volatilidade Eleitoral Contrafactual

Variável Independente: Média de Educação

Unidade: Seção Eleitoral

Significância: *** p<0,01

Fonte: Banco de Dados Eleitorais CEM/CEBRAP

A interpretação que se pode dar para o fato das urnas mais escolarizadas estarem mais associadas com flutuação eleitoral, diferentemente do cenário para governador e presidente, é o fato do PT já encontrar maior inserção nas seções de baixa educação no começo da série aqui analisada. Os locais de maior educação média, por seu turno, alteraram sua preferência eleitoral entre PP, PSDB e DEM, sempre com comportamento contra o PT. 
As bases educacionais dos partidos podem ser encontradas abaixo:

\section{Gráfico 6}

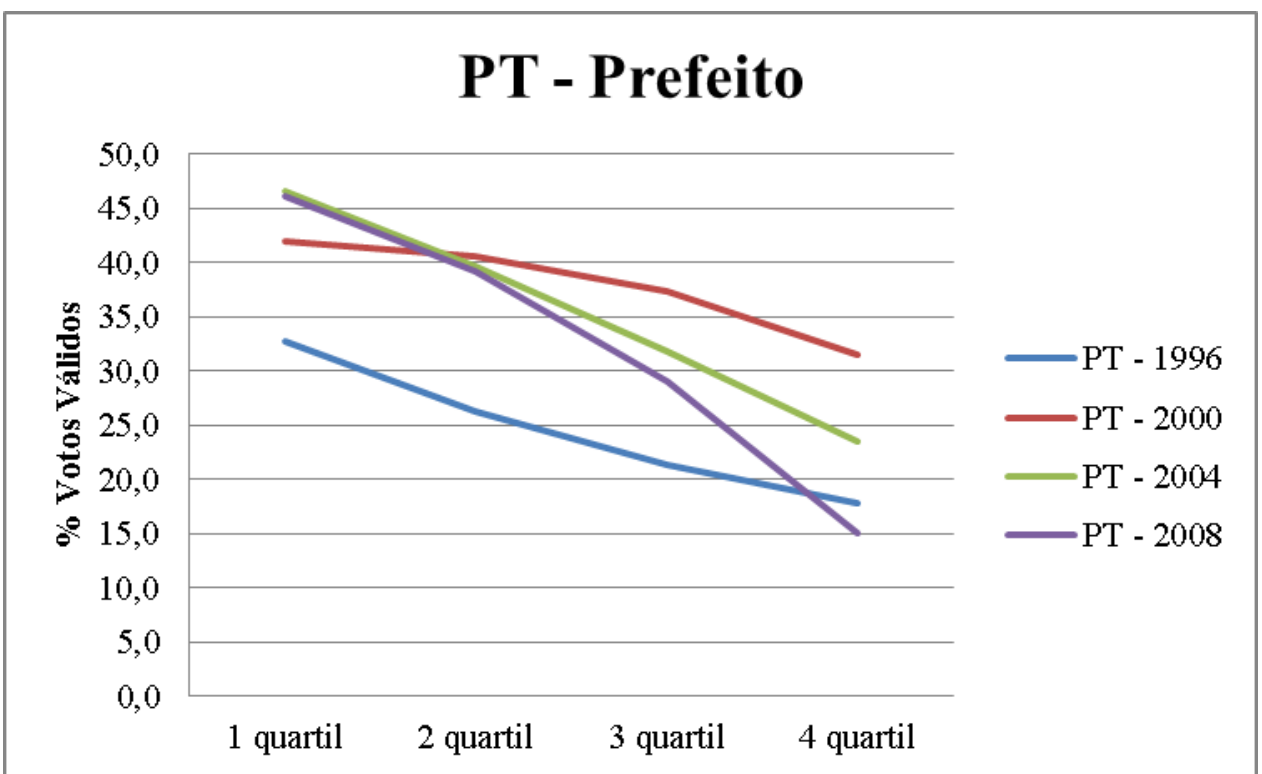

Tabela 35 - Regressão linear simples - PT / Educação - Prefeito

\begin{tabular}{lcccc}
\hline \hline & 1996 & 2000 & 2004 & 2008 \\
\hline Coeficiente da V.I. & $-6,898$ & $-5,479$ & $-11,376$ & $-15,641$ \\
Erro-Padrão & 0,061 & 0,054 & 0,097 & 0,13 \\
Significância & $* * *$ & $* * *$ & $* * *$ & $* * *$ \\
R2 & 0,498 & 0,433 & 0,449 & 0,416 \\
$\mathrm{~N}$ & 13094 & 13735 & 16970 & 20301 \\
\hline \hline
\end{tabular}

Variável Dependente: \% Votos do PT

Variável Independente: Média de Educação

Unidade: Seção Eleitoral

Significância: $* * * p<0,01$

Fonte: Banco de Dados Eleitorais CEM/CEBRAP

Os betas das regressões e a disposição das linhas no gráfico não deixam dúvidas: o apoio do PT na cidade de São Paulo é fortemente influenciado pela distribuição educacional, de modo que o partido recebe muitos votos nas seções de menor educação vis-à-vis as de alta educação. 
Gráfico 7

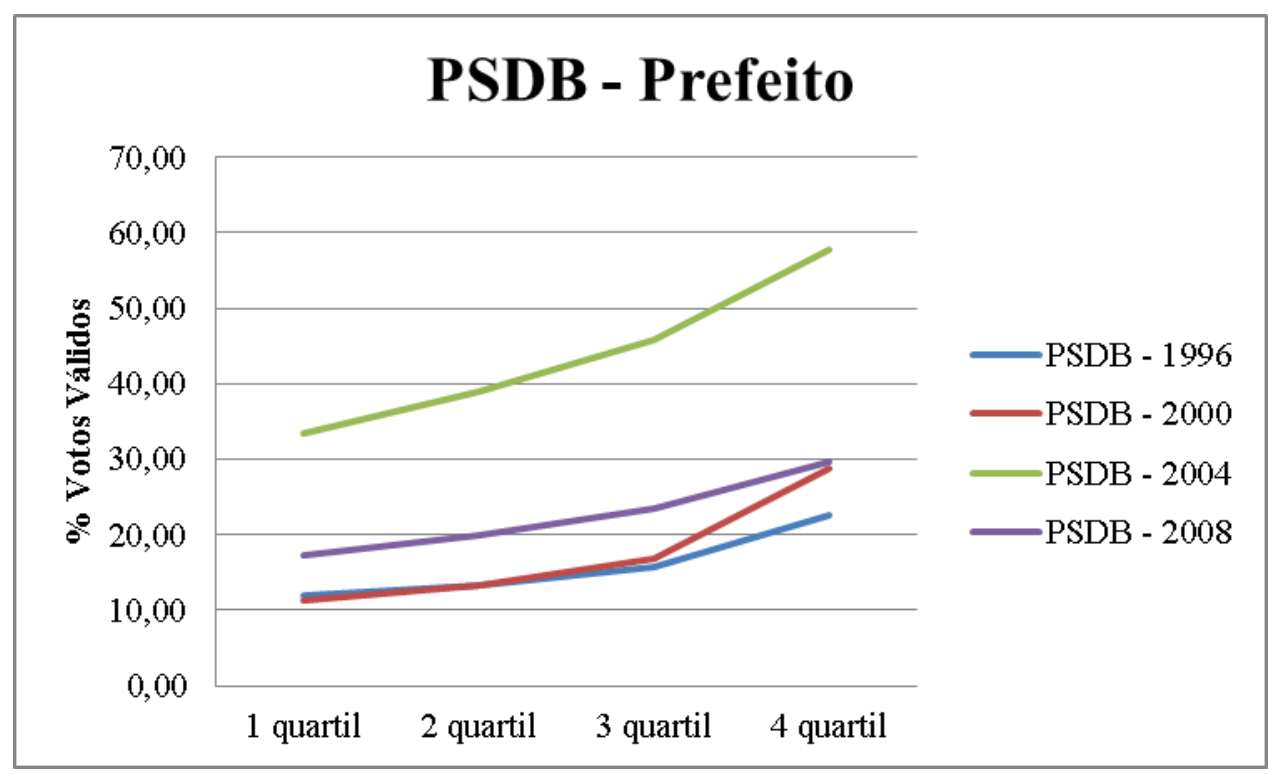

Tabela 36 -Regressão linear simples - PSDB / Educação - Prefeito

\begin{tabular}{lcccc}
\hline \hline & 1996 & 2000 & 2004 & 2008 \\
\hline Coeficiente da V.I. & 5,423 & 9,39 & 12,47 & 6,264 \\
Erro-Padrão & 0,033 & 0,044 & 0,07 & 0,051 \\
Significância & $* * *$ & $* * *$ & $* * *$ & $* * *$ \\
R2 & 0,675 & 0,768 & 0,655 & 0,428 \\
$\mathrm{~N}$ & 13094 & 13735 & 16970 & 20301 \\
\hline \hline
\end{tabular}

Variável Dependente: \% Votos do PSDB

Variável Independente: Média de Educação

Unidade: Seção Eleitoral

Significância: *** $\mathrm{p}<0,01$

Fonte: Banco de Dados Eleitorais CEM/CEBRAP

Os resultados para o PSDB são também bastante nítidos: o partido é sistematicamente mais votado nas urnas de maior escolaridade, e conforme mostram os coeficientes de regressão, essa relação é forte principalmente nos anos de 2000 e 2004.

Por último, o desempenho do PP: 
Gráfico 8

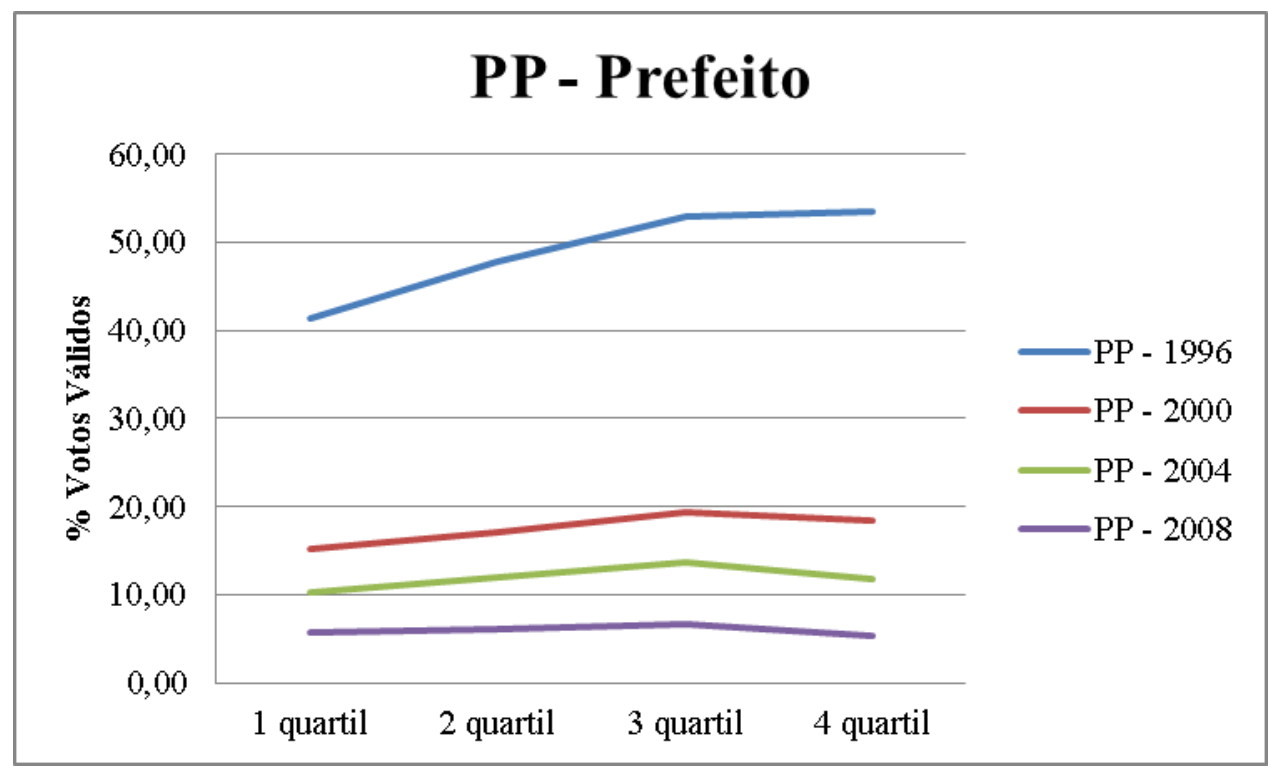

Tabela 37 -Regressão linear simples - PP / Educação - Prefeito

\begin{tabular}{lcccc}
\hline \hline & 1996 & 2000 & 2004 & 2008 \\
\hline Coeficiente da V.I. & 5,326 & 1,251 & 0,359 & $-0,316$ \\
Erro-Padrão & 0,075 & 0,051 & 0,046 & 0,026 \\
Significância & $* * *$ & $* * *$ & $* * *$ & $* * *$ \\
R2 & 0,28 & 0,042 & 0,004 & 0,007 \\
$\mathrm{~N}$ & 13094 & 13735 & 16970 & 20301 \\
\hline \hline
\end{tabular}

Variável Dependente: \% Votos do PP

Variável Independente: Média de Educação

Unidade: Seção Eleitoral

Significância: *** $\mathrm{p}<0,01$

Fonte: Banco de Dados Eleitorais CEM/CEBRAP

A distribuição educacional dos votos do PP revela um padrão diferente dos dois analisados anteriormente: de 96 a 08, a educação por urna passou a ser menos importante para a votação do partido, além de assumir valores negativos. Isso pode estar relacionado com o apoio cada vez menor que essa legenda passou a receber em São Paulo.

\section{Síntese}

A análise dos resultados das eleições municipais da capital do Estado de São Paulo revela um cenário mais matizado que um diagnóstico fruto de um olhar a primeira vista poderia fazer crer. Para além dos diagnósticos similares aos das eleições presidenciais e para governador, as disputas para prefeito revelam uma especificidade 
importante: uma maior divisão educacional das bases dos partidos. PT e PSDB estão fortemente ancorados em urnas de menor e maior educação, respectivamente, desde o começo da série.

Essa divisão social, no entanto, não espelha uma bipolaridade eleitoral consolidada. Mesmo após a queda do PP, forte competidor nos anos 90, o PSDB, por motivos de coordenação interpartidária, não logrou constituir-se um partido hegemônico no pólo oposto ao do PT.

\section{Síntese geral}

Este capítulo buscou apresentar e analisar os resultados das disputas de presidente, governador do Estado de São Paulo e de prefeito da sua capital, de 1994 a 2008, sob o prisma da volatilidade eleitoral. A intenção foi argumentar que as mudanças de voto entre pares de eleição não configuram um cenário errático, no qual os partidos não apresentam bases eleitorais identificáveis e mais ou menos estáveis no tempo.

Abaixo se encontra uma tabela com índices de volatilidade de Pedersen de alguns países, para um esboço de comparação. Esta, no entanto, não deve ser feita sem cuidados, por dois motivos principais: o primeiro é o período considerado: países com longas séries de eleições tendem a ter índices de volatilidade menores, por questões históricas (ver Mainwaring e Zocco (2007); o segundo é a unidade de análise: os autores utilizam os cargos da Câmara Baixa. Entretanto, como foi argumentado aqui, nos países presidencialistas os cargos para o executivo tendem a ser mais importantes.

\begin{tabular}{lcc}
\multicolumn{2}{c}{ Tabela 38 - Volatilidade eleitoral em diversos países - \% } \\
\hline \hline País & Ano de Eleições & Volatilidade Média \\
\hline EUA & $1946-2002$ & 3,3 \\
Suíça & $1943-2003$ & 6,5 \\
Reino Unido & $1945-2001$ & 6,8 \\
Alemanha & $1949-2002$ & 8,7 \\
Suécia & $1911-2002$ & 9 \\
Dinamarca & $1945-2001$ & 11,2 \\
Colômbia & $1958-2002$ & 12,5 \\
Itália & $1946-2001$ & 15,1 \\
Japão & $1952-2000$ & 16,2 \\
Chile & $1989-2001$ & 16,7 \\
Brasil & $\mathbf{1 9 8 6 - 2 0 0 2}$ & $\mathbf{2 1 , 8}$ \\
México & $1988-2000$ & 22,7 \\
Argentina & $1983-2001$ & 24,9 \\
Bolívia & $1985-2002$ & 38
\end{tabular}


Fonte: Adaptado de Mainwaring e Zocco (2007)

Os números apresentados por Mainwaring e Zocco (2007) colocam o Brasil na segunda metade dos países numa ordenação crescente de flutuação eleitoral.

Além disso, os dados apresentados no presente trabalho não distam muito dos índices apresentados pelos autores.

Abaixo se encontram índices de volatilidade de Pedersen para alguns países europeus apenas para os anos 90. A intenção é mostrar que no período recente observou-se um aumento da flutuação eleitoral.

\begin{tabular}{lc}
\multicolumn{2}{c}{ Tabela 39 - Volatilidade eleitoral década de 1990 - \% } \\
\hline \hline Países & Volatilidade Média \\
\hline Suíça & 8 \\
Alemanha & 9 \\
Reino Unido & 9,3 \\
Dinamarca & 12,4 \\
Suécia & 13,8 \\
Itália & 22,9 \\
\hline \hline
\end{tabular}

Fonte: Adaptado de Mair (2008)

A intenção de mostrar esses dados é ressaltar que o ambiente político internacional enfrentado pelos partidos brasileiros no momento de consolidação da democracia é de aumento da volatilidade.

Para além da busca de uma comparação exata, a interpretação que oferecemos busca ressaltar o peso das estratégias dos partidos na conformação da volatilidade. Além disso, o que é importante destacar é a importância teórica da noção de volatilidade. Ao decorrer desta dissertação, procurei mostrar os pressupostos e as implicações de diferentes teorias sobre o conceito de volatilidade. Este capítulo IV, da análise empírica, visou ressaltar que o comportamento de partidos e eleitores em São Paulo não pode ser caracterizado como volátil.

É importante sublinhar que os maiores partidos apresentam base educacional e tendência temporal semelhante nos três níveis federativos de disputa. PT e PSDB sempre apresentaram, no período considerado, correlação com nível educacional das 
urnas, o primeiro em sentido negativo, o segundo, positivo. Cabe notar que nos períodos mais recentes, essa relação ficou mais acentuada.

A flutuação do voto muitas vezes esteve associada à inserção cada vez maior do PT entre os menos escolarizados. A atualização do recorte temporal poderá dizer se a tendência desse grupo em ser mais volátil foi atenuada. Os resultados agregados da última geral, 2010, levam a crer que sim.

\section{Considerações Finais}

O esforço deste trabalho busca proporcionar uma nova interpretação para o fenômeno da volatilidade eleitoral no Brasil (focando no caso de São Paulo), e, assim para a avaliação sobre o papel dos partidos políticos no momento eleitoral. Neste sentido, contribui para discussões acerca da institucionalização do sistema partidário, e, de modo geral, para o funcionamento da democracia no Brasil. A tese defendida é a de que o índice de flutuação do voto é fortemente influenciado pelo comportamento dos partidos, ao decidirem sobre o lançamento de candidaturas, e não revela, necessariamente, um comportamento eleitoral desordenado. A hipótese defendida pode levar, então, a novos testes em outros contextos eleitorais, e logo, trazer novas compreensões ao comportamento eleitoral e à dinâmica do sistema partidário no Brasil.

Esse argumento é construído tanto teórica quanto empiricamente. Na parte teórica, passou-se por diversas visões sobre o comportamento volátil do eleitor. $\mathrm{Na}$ literatura tradicional européia, o eleitor inconstante é causa e consequiência de processos de desalinhamento do sistema partidário com as clivagens da sociedade, numa situação de crise do sistema de representação protagonizado pelos partidos. Na perspectiva do desenvolvimento político, notadamente Huntington, o eleitor volátil é típico de contextos políticos não institucionalizados, nos quais o cidadão localizado nas menores posições da estratificação social, principalmente, assumiriam comportamentos radicalizados sem o devido "freio" das instituições políticas. Nas teorias do comportamento eleitoral, observou-se que as abordagens sociológica e sóciopsicológica enfatizam o caráter marginal do eleitor inconstante: este não teria laços de pertencimento estáveis com grupos da sociedade ou então teria um sistema de crenças desordenado. 
Um dos objetivos dessa dissertação é trazer outro olhar para o eleitor flutuante. Para tanto, procurei mobilizar uma literatura preocupada com estratégias partidárias e competição eleitoral. De caráter mais formal e assentado em outros debates, esse conjunto de discussões permitiu levantar a importância das estratégias partidárias no comportamento do eleitor.

Assim, ainda voltado para as questões substantivas do debate da volatilidade no Brasil, procurei ressaltar a necessidade de se incorporar os constrangimentos impostos pela mudança na oferta partidária para a decisão de voto do eleitor. Legendas entram e saem da competição eleitoral, muitas vezes impossibilitando que eleitores mantenham seu comportamento estável.

Ainda no âmbito teórico, procurei ressaltar que as mazelas normativas muitas vezes atribuídas ao fenômeno da volatilidade não são tão óbvias. Pelo contrário, pode-se pensar em muitos pontos do debate da teoria democrática e da teoria dos partidos nos quais a mudança de voto do eleitor, e a possibilidade a ele oferecida de agir dessa forma, é um valor positivo.

Do ponto de vista empírico, proponho a mudança de foco nos estudos sobre o sistema partidário: defendo que se deve conceder primazia aos cargos executivos, também na análise da volatilidade eleitoral. Os resultados apresentados no capítulo IV mostram que grande parte da flutuação se deve à alteração do quadro partidário, e não está mais associada a eleitores com maior ou menor educação.

Além disso, os dados apontam uma tendência de homogeneidade nos padrões de disputa nos três níveis federativos em São Paulo, não apenas no que se refere às legendas ou coligações partidárias efetivamente vencedoras, mas também no perfil social de apoio de cada postulante. Isso é uma evidência da institucionalização do sistema partidário, no sentido da construção de identidades estáveis com grupos da sociedade.

No entanto, como conciliar os achados e os argumentos deste trabalho com o fato de que os eleitores brasileiros, na sua maioria, não se identificam com os partidos (Veiga, 2007), têm baixa memória sobre a direção de seus votos passados (Nicolau, 2006: 704), avaliam de forma muito negativa os partidos (Moisés, 2010) e, algumas 
vezes, não conseguem ligar o nome de conhecidas lideranças a suas respectivas legendas (Kinzo, 2007)?

Não nego a pertinência e a importância, tanto analítica quanto normativa, desses achados. Nada obstante, busco ressaltar outros pontos:

(1) A literatura internacional sobre teoria dos partidos políticos é quase unânime em ressaltar a mudança de seu papel nas atuais configurações democráticas. Em linhas gerias, argumenta-se que o crescimento e atualização dos meios de comunicação, a perda de fôlego dos movimentos de esquerda com o fim da União Soviética, uma maior homogeneidade econômico-social entre os cidadãos após anos de welfare-state (neste caso, fator muito mais forte na Europa Ocidental que alhures), dentre outras variáveis impactaram fortemente a essência e a atuação das legendas partidárias. Ainda que exista um debate sobre o impacto dessas transformações sobre a força dos partidos, seja do ponto de vista teórico, seja empírico-analítico (ver Manin, 1995; Dalton, 2004; Katz e Mair, 2009, dentre outros), existe hoje um certo consenso de que, parafraseando Schimitter (2001), os partidos não são o que costumavam ser. Assim, dado que nosso sistema partidário foi formado nos anos $80 \mathrm{e}$ 90, e dado que a maior parte das condições causais expostas também podem ser encontrada no caso brasileiro, penso que exigir elevados níveis de identificação partidária, de filiação, de confiança nos partidos ou de relação entre esses e a sociedade civil é, em certo nível, pelos motivos expostos acima, irrealista e anacrônico.

(2) Outro ponto é o status teórico da identificação partidária. Esse fenômeno é passível de diversas interpretações pelas diferentes teorias do comportamento eleitoral. $\mathrm{Na}$ abordagem da escolha racional, a IP é vista como um atalho de informação, no qual eleitores "racionalmente ignorantes" utilizam como balizador da decisão do voto. No cenário contemporâneo, no qual os partidos não ocupam um lugar tão proeminente quanto os modelos de partidos de massa ocuparam outrora, pode-se problematizar a interpretação psico-sociológica da IP. Visto que as agremiações não realizam importantes papéis de socialização política, 
a IP pode ser vista como apenas mais um recurso possível para decisão do voto. Utilizando-se da abordagem de Idema (2009), eleitores filtram em vários níveis os partidos, com base em suas preferências, independente de expressarem identificação. Ademais, utilizando-se da proposta de Carreirão e Kinzo (2004), parece-me promissora analiticamente a idéia de uma identificação negativa: diz respeito a eleitores que rejeitam determinados partidos e votam nos seus oponentes mais competitivos. O PT talvez seja o partido que mais se encaixe nesse perfil: abarca a maioria do eleitorado que se identifica com algum partido, mas também sofre a maior rejeição.

(3) Por fim, a associação entre a votação nos diferentes níveis sociais e os diferentes partidos, tal como procura demonstrar esta dissertação, pode indicar uma construção de representação dos principais partidos brasileiros no comportamento dos eleitores. Logo, mesmo em condições históricas e institucionais diferentes das preconizadas pelo modelo do partido de massas, pode-se pensar na possibilidade de outros mecanismos atuarem no estabelecimento de ligação estável entre partido e eleitor.

\section{Bibliografia:}

Achen, Christopher H. (1977) "Measuring Representation: Perils of the Correlation Coefficient” American Journal of Political Science 21: 805-815.

Aldrich, John. (1995). Why parties? The origin and transformation of political parties in America. The University of Chicago Press, Chicago.

Ames, Barry (1995a) "Electoral strategy under open-list proportional representation". American Journal of Political Science, vol. 39, n.2. (1995b). "Electoral Rules, Constituency Pressures, and Pork Barrel: Bases of Voting in the Brazilian Congress," Journal of Politics 57(2).

Bakke, Elisabeth; Sitter, Nick. (2005) "Patterns of stability: party competition and strategy in Central Europe since 1989", Party Politics, vol.11, p. 243-63.

Barnes, Samuel; McDonough, Peter e Pina, Antonio López. (1985) “The development of partisanship in new democracies: the case of Spain". American Journal of Political Science, Wisconsin, University of Wisconsin Press, n. 29. 
Bartolini, Stefano (1999) "Collusion, competition and democracy: part I", Journal of Theoretical Politics, 11(4), 435-470.

; Mair, Peter. (1990) Identity, competition, and electoral availability.

Cambridge University Press, Cambridge.

Bohn, Simone; Paiva, Denise. (2009). "A volatilidade eleitoral nos estados: sistema partidário e democracia no Brasil ”. Revista de Sociologia e Política, v. 17, n. 33, p. 187-208.

Bone, Hugh A. e Ranney, Austin. (1966) "Configuração e psicologia do ato de votar" in Bone, H. e Ranney, A. A política e o eleitor. Editora Presença, Rio de Janeiro.

Braga, Maria do Socorro Souza. (2006). O processo partidário-eleitoral brasileiro. Ed. Humanitas/FAPESP, São Paulo.

Calvo, Ernesto; Murillo, Maria Victoria. (2004) "Who delivers? Partisan clients in the Argentina electoral market", American Journal of Political Science, v. 48, n.4.

Campbell, Angus; Converse, Philip; Miller, Warren; Stokes, Donald. (1980) The American Voter. University of Chicago Press, Chicago.

Cardoso, Fernando Henrique e Lamounier, Bolívar (1975). Partidos e Eleições no Brasil. Paz e Terra, Rio de Janeiro.

Carey, John (1997) "Institutional design and party system" in Diamond, Plattner e Tien (eds.) Consolidating the third wave democracies. Baltimore: The Johns Hopkins University Press, 1997.

; Shugart, Matthew. (1995) "How to Cultivate a Personal Vote: A Rank Ordering of Electoral Formulas". Electoral Studies, vol. 14, n. 4.

Carmines, Edward e Huckfeldt, Robert (1998). "Political Behavior: An Overview." In Goodin, Robert e Klingemann, Hans-Dieter (ed.) A New Handbook of Political Science. Oxford University Press, Oxford.

Carreirão, Yan de Souza. (2002) A decisão do voto nas eleições presidenciais brasileiras. Ed. FGV/ Ed. UFSC, Rio de Janeiro/Florianópolis. ; Kinzo, Maria D'Alva. (2004) "Partidos Políticos, Preferência

Partidária e Decisão Eleitoral no Brasil (1989/2002)”. Dados, vol. 47, n. 1, p. 131-168.

Castro, Mônica Mata Machado. (1992). "Indivíduo e estrutura no comportamento eleitoral”, Revista Brasileira de Ciências Sociais, n. 20, p.7-20.

Converse, Philip E. (1979) "Os sistemas de crenças” in Cardoso, F.H. e Martins, C. E. Política e sociedade. Companhia Editora Nacional, São Paulo.

Cortez, Rafael. (2009) Eleições majoritárias e entrada estratégica no sistema partidário-eleitoral brasileiro: 1989-2006. Tese de Doutorado. DCP-USP

Cox, Gary; McCubbins, Mathew D. (1986) "Electoral Politics as a Redistributive Game". Journal of Politics 48: 370-89. . (1997) Making Votes Count. Cambridge University Press, Cambridge. . (2010) "Core voter, swing voter and distributive politics" in Shapiro, Ian;

Stokes, Susan; Wood, Elisabeth Jean; Kirshner, Alexander (eds.). Political Representation. Cambridge University Press, Cambridge. 
. (2005) "Electoral institutions and political competition: coordination, persuasion and mobilization”. In Ménard, Claude ; Shirley, Mary (ed.) Handbook of new institutional economics, Springer, Berlin.

; Amorim Neto, Octávio (1997). "Electoral institutions, cleavage structures and the number of parties", American Journal of Political Science, v. 14,

Dahl, Robert. (1997) Poliarquia: Participação e Oposição. Edusp, São Paulo.

Dalton, Russel J. (2004) Democratic Challenges, Democratic Choices. Oxford University Press, Oxford.

Diaz-Cayeros, Alberto; Estévez, Federico; Magaloni, Beatriz (2007) "The core voter model: evidence from Mexico". Leitner Program Working Papers, disponível em http://www.isn.ethz.ch/isn/Digital-Library/Publications/Detail/?ots591=0c54e3b3-1e9cbe1e-2c24-a6a8c7060233\&lng=en\&id=45863.

Downs, Anthony. (1999) Uma teoria econômica da democracia. Edusp, São Paulo.

Duverger, Maurice. (1987) Os partidos políticos. Ed. Guanabara, Rio de Janeiro.

Elster, Jon. (1994) Peças e engrenagens das Ciências Sociais. Ed. Relume-Dumará, Rio de Janeiro.

Fearon, James. (1991) "Counterfactuals and hypothesis testing in political science", World Politics, vol. 43, n. 2, p. 169-95.

Figueiredo, Argelina; Limongi, Fernando. (1999) Executivo e Legislativo na Nova Ordem Constitucional. Ed. FGV, Rio de Janeiro.

Figueiredo, Marcus. (1995) "Volatilidade eleitoral nas eleições parlamentares, 19501978”. Opinião Pública, vol. III, n. 3, p. 121-27. .(1991) A decisão do voto: Democracia e Racionalidade. Ed.

Sumaré/Anpocs, São Paulo.

Figueiredo Filho, Dalson Britto e Silva, José Alexandre. (2009) "Desvendando os mistérios do coeficiente de correlação de Pearson (r)", Revista Política Hoje, vol. 18, n.1.

Fiorina, Morris. (1981) Retrospective Voting in American National Elections. Yale University Press, New Haven.

Gerring, John (2004) "What Is a Case Study and What Is It Good for?", American Political Science Review, vol. 98, n.2.

Huckfeldt, Robert; Sprague, John. (1995) Citizens, Politics, and Social Communication. Cambridge University Press, Cambridge.

Huntington, Samuel (1975) A Ordem Política nas Sociedades em Mudança, Ed. Forense, Rio de Janeiro.

Idema, Tilmo. (2009) "Core voters or swing voters? The distributive politics of higher education spending". Paper apresentado no Institutions and Inequality Conference, Department of Politics and International Relations, University of Oxford. Disponível em http://tim.hicks.me.uk/conference2009/papers/pdfs/Idema2009.pdf. 
Katz, Richard ; Mair, Peter (1995). "Changing models of party organization and party democracy: the emergence of the cartel party". Party Politics, v.1, n.1, pp. 5-28. . (2009) "The cartel party thesis: a restatement". Perspectives on Politics, vol.7, n.4, p.753-66.

King, Gary. (1986) "How Not to Lie with Statistics: Avoiding Common Mistakes in Quantitative Political Science". American Journal of Political Science 30:666-687.

Kinzo, Maria D`Alva. (2004) "Partidos, Eleições e Democracia no Brasil pós 1985”. Revista Brasileira de Ciências Sociais, vol. 19, n. 54. . (2007) "Os partidos no eleitorado: percepções políticas e laços partidários” In Kinzo, Maria D`Alva e Braga, Maria do Socorro (orgs.) Eleitores e representação partidária no Brasil. Ed. Humanitas, São Paulo.

Kirchheimer, Otto. (1990) "The catch-all party" in Mair, Peter (org.).The West European Party System. Oxford University Press, Oxford.

Kitschelt, Herbert (2000). "Linkages between citizens and politicians in democratic polities". Comparative Political Studies, v. 33, n. 6/7.

Kramer, Gerald. (1971) "Short-Term Fluctuations in U.S. Voting Behavior: 19861964". American Political Science Review, Vol. 65.

Lamounier, Bolívar. (1994) “A Democracia brasileira de 1985 à década de 1990: a síndrome da paralisia hiperativa" in João Paulo dos Reis (org.) Governabilidade, sistema político e violência urbana. Ed, José Olympio, Rio de Janeiro.

Lane, Jan-Erik e Ersson, Svante. (1997) "Parties and Voters: what creates the ties?" Scandinavian Political Studies, vol. 20, n. 2.

Lavareda, Antônio. (1991) A Democracia nas Urnas. Iuperj/Rio Fundo Editora, Rio de Janeiro.

Lazarsfeld, Paul; Berelson, Bernard; Gaudet, Hazel (1948) The People`s Choice: How the Voter Makes Up His Mind in a Presidential Campaign. Columbia University Press, New York.

Leoni, Eduardo. (2002) "Ideologia, Democracia e Comportamento Parlamentar: A Câmara dos Deputados (1991-1998)". Dados, 45 (3).

Lima, Marcelo Coutinho. (1996) "Volatilidade eleitoral em São Paulo, 1985-92". Novos Estudos Cebrap, n. 46, p. 21-38.

Limongi, Fernando. (2000) "Institucionalização Política" in Miceli, Sergio (org.). O que ler na ciência social brasileira (1970-1995), vol.3, Ed. Sumaré/ANPOCS, São Paulo. . (2002) "Debate Institucional e democracia no Brasil: O problema do sistema partidário" in Perissinotto, Renato e Fuks, Mario. Democracia: Teoria e Prática. Ed. Relume- Dumará, Rio de Janeiro. ; Mesquita, Lara. (2008) “As eleições municipais em São Paulo entre 1985-2004”. Novos Estudos Cebrap, vol. 81, p. 49-67. ; Cortez, Rafael. (2010) "As eleições de 2010 e o quadro partidário". Novos Estudos Cebrap, vol.88, p. 21-37. 
Linz, Juan. (1991) “Presidencialismo ou Parlamentarismo: Faz Alguma Diferença?” in Lamounier, Bolívar (org.) A Opção Parlamentarista. Sumaré/IDESP, São Paulo.

Lipset, Seymor. (1975) O Homem Político. Ed. Zahar, Rio de Janeiro. ; Rokkan, Stein (1990) "Cleavage Structures, Party Systems, and Voter Alignments" in Mair, Peter (org.) The West European Party System. Oxford University Press, Oxford.

Lybeck , Johan A. (1985) “Is the Lipset-Rokkan hypothesis testable?”. Scandinavian Political Studies, vol.8, n. 1-2, p.105-13.

Mainwaring, Scott; Scully, Timothy. (1994) "A institucionalização dos sistemas partidários na América Latina”. Dados, vol. 37, n.1, p. 43-79. ; Tocal, Mariano. (2005) "Teoria e institucionalização dos sistemas partidários após a terceira onda de democratização". Opinião Pública, vol. XI, n.2, p.249-86.

; Zoco, Edurne. (2007) "Political sequences and the stabilization of interparty competition: electoral volatility in old new democracies", Party Politics, v. 13, n.2.

; Meneguello, Rachel e Power, Timoty (2000). Partidos conservadores no Brasil contemporâneo. Paz e Terra, São Paulo.

Mair, Peter (1997) Parties System Change. Oxford University Press. . (2008) "Electoral volatility and the dutch party system: a comparative perspective". Acta Politica, 43, 235-253. . (2009) "Representative versus responsible government". MPlfG Working Paper, Max Planck institute for the study of societies, Cologne.

Manin, Bernard. (1987) "On legitimacy and political deliberation" Political Theory, v.15 (1995) "As metaformoses do governo representativo". Revista Brasileira de Ciências Sociais, n.29.

Melo, Carlos Ranulfo Melo (2007) "Nem tanto ao mar, nem tanto à terra: elementos para uma análise do sistema partidário brasileiro" in Melo, Carlos Ranulfo; Saéz, Manuel Alcântara (orgs.) A democracia brasileira: balanços e perspectivas para o século 21. Ed. UFMG, Belo Horizonte.

Meneguello, Raquel. (1996) Partidos e governos no Brasil Contemporâneo (19851995). Tese de Doutorado, IFCH-Unicamp.

Moisés, José Álvaro. (2010) “Os significados da democracia segundo os brasileiros”, Opinião Pública, vol. 16, n.2, p. 269-309.

Nicolau, Jairo (2010) "Partidos e sistemas partidários: 1985-2009” in Martins, Carlos Benedito; Lessa, Renato. (org.). Horizontes das Ciências Sociais no Brasil: Ciência Política, São Paulo. Nova, n. 36 . ; Schmitt, Rogério. (1995) "Sistema eleitoral e sistema partidário", Lua . (1998) "Volatilidade eleitoral nas eleições para a Câmara dos Deputados brasileira (1982-1994)". Paper apresentado no XXII Encontro Anual da Anpocs, Caxambu-MG. .(2004) "Partidos na República de 1946: Velhas Teses, Novos Dados". 
Dados, vol.47, n.1, pp.85 a 129.

; Peixoto, Vitor. (2007) "Uma disputa em três tempos: uma análise das bases municipais das eleições presidenciais de 2006". Paper apresentando no encontro anual da Anpocs, Caxambu-MG.

p. $689-720$. . (2006) "O sistema eleitoral de lista aberta no Brasil". Dados, vol. 49, n. 4,

Novais, Carlos Alberto. (1996) “A geografia do voto em São Paulo”, Novos Estudos São Paulo, n. 45.

Nunes Leal, Vítor. (1975) Coronelismo, Enxada e Voto: O município e o regime representativo no Brasil. Alfa-Ômega, São Paulo.

Pedersen, Morgens. (1990) "Electoral Volatility in Western Europe: 1948-1977" in Mair, Peter (org.).The West European Party System. Oxford University Press, Oxford.

Pereira, Carlos e Muller, Bernardo. (2003). "Partidos fracos na arena eleitoral e partidos fortes na arena legislativa: a conexão eleitoral no Brasil”. Dados, vol. 46, n. 4.

Peres, Paulo. (2000) O espectro da instabilidade: Sistema Partidário e Volatilidade Eleitoral no Brasil Democrático. Dissertação de Mestrado, DCP-USP. . (2005) "O problema da instabilidade eleitoral na Europa: uma análise do debate teórico, empírico e metodológico", $B I B, \mathrm{n}^{\circ}$ 60, São Paulo.

Pierucci, Antonio Flávio; Lima, Marcelo Coutinho. (1991) “A Direita que Flutua”. Novos Estudos CEBRAP, n. 29, p. 10 a 27.

CEBRAP, n. 35, p. 94 a 99. . (1993) "São Paulo 92, a vitória da direita". Novos Estudos

Pizzorno, Alessandro. (1966) "Introduccion al studio de la participación política", in Pizzorno, Alessando; Kaplan, Marcos; Castells, Manuel. Participación y cambio social em la problemática contemporânea. Ediciones Siap - Planteos.

Powell, Eleanor e Tucker, Joshua. (2009) "New aproaches to electoral volatility: evidence from postcommunist countries", paper apresentado na 2009 Annual Meetting of the American Political Science Association, Toronto, Canadá.

Powell Jr., G. Bingham; Whitten, Guy. (1993) “A Cross-national analysis of economic voting: taking account of the political context", American Journal of Political Science, v. 37, n.2.

Praça, Sérgio. (2007) "Coordenação eleitoral e de elite em sistemas proporcionais: o caso paulistano em 2000.” In Kinzo, Maria D`Alva e Braga, Maria do Socorro (orgs.). Eleitores e representação partidária no Brasil. Ed. Humanitas, São Paulo.

Przeworski, Adam. (1975) "Institucionalization of Voting Patterns, or is Mobilization the Source of Decay?” American Political Science Review, vol. 69, n. 1, p. 49-67. Cebrap, n.9, p.36-46. . (1984) "Ama a incerteza e serás democrático". Novos Estudos . (1989) "Estratégia partidária, organização de classe e votação individual" in Przeworski, Adam. Capitalismo e Social-Democracia. Companhia das Letras, São Paulo.

Reis, Fábio Wanderley (org.). (1978) Os Partidos e o Regime. Ed. Símbolo, São Paulo. 
Rennó, Lúcio; Peres, Paulo; Ricci, Paolo. (2011) "Variação da Volatilidade Eleitoral no Brasil: Um Teste das Explicações Políticas, Econômicas e Sociais”. Latin American Research Review, (no prelo). $B I B$, n. 51, p. 85-103. .(2001) "A estrutura das crenças de massa e seu impacto na decisão do voto". ; Spanakos, Anthony. (2006) "Fundamentos da Economia, Mercado Financeiro e Intenção de Voto: As Eleições Presidenciais Brasileiras de 1994, 1998 e 2002". Dados, vol. 49, n. 1, p.11-41.

Roberts, Kenneth ; Wibbels, Erik. (1999) "Party systems and electoral volatility in Latin America: a test of economic, institutional and structural explanations". American Political Science Review, vol. 93, n. 3, p. 575-90.

Rose, Richard e Urwin, D. (1990) "Persistence and Change in Western Party Systems since 1945" in Mair, Peter (org.). The West European Party System. Oxford, Oxford University Press.

Sartori, Giovanni. (1968) "Political development and political engineering" in Montgomery, J.D. e Hirschman, A. O. (orgs.). Public Policy, vol. 17, p. 261-298. Mass. Harvard University Press, Cambridge. (1982) Partidos e Sistemas Partidários, Ed. Zahar, Rio de Janeiro.

Schimitter, Phillippe. (2001) "Parties are not what they once were" in Diamond, Larry e Gunther, Richard (orgs.). Political parties and democracy, John Hopkins University Press, Baltimore and London.

Schumpeter, Joseph. (1984) Capitalismo, Socialismo e Democracia. Fundo de Cultura, Rio de Janeiro.

Silveira, Flávio. (1996) O Novo Eleitor Não-Racional. Tese de Doutorado, FFLCHUSP, Departamento de Sociologia.

Simão, Aziz. (1956) “O voto operário em São Paulo". Revista Brasileira de Estudos Políticos, n.1, p. 130-41.

Singer, André. (2000) Direita e Esquerda no Eleitorado Brasileiro. Edusp, São Paulo. .(1990) "Collor na periferia: a volta por cima do populismo?" in

Lamounier, Bolívar (org.). De Geisel a Collor: o balanço da transição. Sumaré/Idesp, São Paulo.

(2009) "Raízes sociais e ideológicas do lulismo”. Novos Estudos Cebrap, vol. 85.

Souza, Amaury de. (1972) "Determinismo social, racionalidade e o voto flutuante em 1960”. Dados, vol. 9, p. 135-45.

Stoll, Heather. (2005) Social cleavages, political institutions and party systems: putting preferences back into the fundamental equation of politics. $\mathrm{PhD}$. Thesis, Stanford University.

Stokes, Donald. (1965) "Spatial models of party competition", American Political Science Review, 57: 368-77.

Stokes, Susan. (2005) "Peverse accountability: a formal model of machine politics with evidence from Argentina”. American Political Science Review, vol.99, n. 3, p. 315-25. 
Tavits, Margit. (2005) "The development of stable party support: electoral dynamics in post-communist Europe”. American Journal of Political Science, vol. 49, n. 2, p. 28398.

Tetlock, Philip e Belkin, Aaron. (1996) "Counterfactual thought experiments in world politics" in Tetlock, Philip e Belkin, Aaron (orgs.) Counterfactual thought experiments in world politics, Princeton University Press.

Veiga, Luciana. (2007) "Os partidos brasileiros na perspectiva dos eleitores: mudanças e continuidades na identificação partidária e na avaliação das principais legendas após 2002”. Opinião Pública, vol. 13, n.2, p. 340-65.

Weffort, Francisco. (1965) "Raízes sociais do populismo em São Paulo". Revista Civilização Brasileira, n.2.

Wolinetz, Steven. (1990) "The transformation of Western European Party Systems" in Mair, Peter (org.). The West European Party System. Oxford University Press, Oxford.

Zucco, César. (2009) "Ideology or What? Legislative Behavior in Multiparty Presidential Settings" The Journal of Politics, 71(3), p.1076-1092. 


\section{Anexo 1}

\section{Resumo de parte da bibliografia sobre volatilidade no Brasil:}

\section{Quadro - 10 Resumo da discussão nacional de volatilidade}

\begin{tabular}{|c|c|c|c|c|c|c|}
\hline AUTOR & $\begin{array}{l}\text { DATA DO } \\
\text { ESTUDO }\end{array}$ & $\begin{array}{l}\text { PERÍODO } \\
\text { HISTÓRICO }\end{array}$ & CARGO & ELEIÇÕES & DISCUSSÃO GERAL & CONCLUSÃO GERAL \\
\hline Souza & 1972 & Brasil 46-64 & Presidente & 1960 & $\begin{array}{l}\text { Comportamento eleitoral } \\
\text { e volatilidade }\end{array}$ & $\begin{array}{l}\text { Teoria da Escolha Racional é a } \\
\text { mais apropriada para explicar } \\
\text { volatilidade }\end{array}$ \\
\hline Lavareda & 1991 & Brasil 46-64 & $\begin{array}{l}\text { Todos estaduais } \\
\text { e nacionais }\end{array}$ & 1945 a 62 & $\begin{array}{l}\text { Institucionalização do } \\
\text { Sistema partidário }\end{array}$ & $\begin{array}{l}\text { Partidos passavam por processos } \\
\text { de institucionalização }\end{array}$ \\
\hline $\begin{array}{l}\text { Lima e } \\
\text { Pierucci }\end{array}$ & 1991 & São Paulo 1990 & Governador & 1990 & Comportamento eleitoral & $\begin{array}{l}\text { Classe alta faz uma escolha } \\
\text { conjuntural pela direita para } \\
\text { barrar o PT }\end{array}$ \\
\hline Idem & 1993 & São Paulo 1992 & Prefeito & 1992 & Comportamento eleitoral & $\begin{array}{l}\text { Classe alta permanece fiel à } \\
\text { direita, retomando seu } \\
\text { comportamento nos anos } 70\end{array}$ \\
\hline $\begin{array}{l}\text { Mainwaring } \\
\text { e Scully }\end{array}$ & 1994 & América Latina & $\begin{array}{l}\text { Dep. Federal e } \\
\text { Presidente }\end{array}$ & 1960 a 93 & $\begin{array}{l}\text { Institucionalização do } \\
\text { Sistema partidário }\end{array}$ & $\begin{array}{l}\text { Partidos na A. Latina são pouco } \\
\text { institucionalizados }\end{array}$ \\
\hline Figueiredo & 1995 & $\begin{array}{l}\text { Brasil: } \\
\text { democracia de } 46 \\
\text { e regime } 64\end{array}$ & Dep. Federal & 1950 a 78 & Volatilidade eleitoral & $\begin{array}{l}\text { Variáveis sociológicas, } \\
\text { institucionais e políticas } \\
\text { explicam a volatilidade }\end{array}$ \\
\hline Lima & 1996 & São Paulo pós 85 & Executivos & 1985 a 92 & Comportamento eleitoral & $\begin{array}{l}\text { Não existe correlação entre } \\
\text { classe social e volatilidade }\end{array}$ \\
\hline Nicolau & 1998 & Brasil pós 82 & $\begin{array}{l}\text { Dep. Federal e } \\
\text { Estadual }\end{array}$ & 1982 a 98 & Volatilidade eleitoral & $\begin{array}{l}\text { Volatilidade varia por Estado e } \\
\text { cargo, e está associada à } \\
\text { migração partidária }\end{array}$ \\
\hline $\begin{array}{l}\text { Roberts e } \\
\text { Wibbels }\end{array}$ & 1999 & $\begin{array}{l}\text { América Latina } \\
\text { pós } 80\end{array}$ & $\begin{array}{l}\text { Dep. Federal e } \\
\text { Presidente }\end{array}$ & 1980 a 97 & Volatilidade eleitoral & $\begin{array}{l}\text { Economia e mudanças } \\
\text { institucionais explicam } \\
\text { volatilidade }\end{array}$ \\
\hline Peres & 2000 & Brasil pós 82 & Dep. Federal & 1982 a 98 & Volatilidade eleitoral & $\begin{array}{l}\text { Volatilidade ideológica não é } \\
\text { elevada e partidos tendem a se } \\
\text { institucionalizar }\end{array}$ \\
\hline Nicolau & 2004 & Brasil 46-64 & Dep. Federal & 1945 a 62 & $\begin{array}{l}\text { Institucionalização do } \\
\text { Sistema partidário }\end{array}$ & $\begin{array}{l}\text { Volatilidade eleitoral era baixa e } \\
\text { partidos estavam } \\
\text { institucionalizados }\end{array}$ \\
\hline Kinzo & 2005 & Brasil pós 88 & Dep. Federal & 1982 a 02 & $\begin{array}{l}\text { Institucionalização do } \\
\text { Sistema partidário }\end{array}$ & $\begin{array}{l}\text { Volatilidade não tende a cair e } \\
\text { partidos não são enraizados } \\
\text { socialmente }\end{array}$ \\
\hline Tavitis & 2005 & $\begin{array}{l}\text { Leste Europeu } \\
\text { pós } 1989\end{array}$ & Dep. Federal & 1992 a 03 & Volatilidade eleitoral & $\begin{array}{l}\text { Além das variáveis sociais, } \\
\text { institucionais e econômicas, } \\
\text { fator tempo é importante }\end{array}$ \\
\hline $\begin{array}{l}\text { Mainwaring } \\
\text { e Torcal }\end{array}$ & 2005 & $\begin{array}{l}\text { Democracias pós } \\
1978\end{array}$ & Dep. Federal & 1978 a 03 & $\begin{array}{l}\text { Institucionalização do } \\
\text { Sistema partidário }\end{array}$ & $\begin{array}{l}\text { Volatilidade no terceiro mundo é } \\
\text { praticamente crônica }\end{array}$ \\
\hline Braga & 2006 & Brasil pós 82 & $\begin{array}{l}\text { Dep. Federal e } \\
\text { Estadual }\end{array}$ & 1982 a 02 & $\begin{array}{l}\text { Institucionalização do } \\
\text { Sistema partidário }\end{array}$ & $\begin{array}{l}\text { Partidos passam por processos } \\
\text { de institucionalização }\end{array}$ \\
\hline $\begin{array}{l}\text { Bohn e } \\
\text { Paiva }\end{array}$ & 2009 & Brasil pós 82 & $\begin{array}{l}\text { Todos estaduais } \\
\text { e nacionais }\end{array}$ & 1982 a 06 & Volatilidade eleitoral & $\begin{array}{l}\text { Volatilidade apresenta tendência } \\
\text { de queda em quase todos os } \\
\text { níveis }\end{array}$ \\
\hline $\begin{array}{l}\text { Rennó, } \\
\text { Peres e } \\
\text { Ricci }\end{array}$ & 2011 & Brasil pós 82 & Dep. Federal & 1982 a 06 & Volatilidade eleitoral & $\begin{array}{l}\text { Variáveis sociais, político- } \\
\text { institucionais e econômicas } \\
\text { explicam volatilidade }\end{array}$ \\
\hline
\end{tabular}




\section{Anexo 2}

Número e percentual de votos válidos restantes após os procedimentos de relacionamento entre bancos de dados:

Votos Válidos - par de eleições Volatilidade Presidente

\begin{tabular}{lccc}
\hline \hline & $1994-1998$ & $1998-2002$ & $2002-2006$ \\
\hline ano 1 & 1994 & 1998 & 2002 \\
\hline votos usados & 15183933 & 15838331 & 18869705 \\
total de votos & 15570323 & 16612001 & 19749403 \\
\% mantida & 97,5 & 95,3 & 95,5 \\
\hline ano 2 & 1998 & 2002 & 2006 \\
\hline votos usados & 15003139 & 17502806 & 16675815 \\
Total & 16612001 & 19749403 & 22009043 \\
\% mantida & 90,3 & 88,6 & 75,8 \\
\hline \hline
\end{tabular}

Fonte: Banco de dados Eleitorais CEM/CEBRAP

Votos Válidos - par de eleições

Volatilidade Governador

\begin{tabular}{lccc}
\hline \hline & $1994-1998$ & $1998-2002$ & $2002-2006$ \\
\hline ano 1 & 1994 & 1998 & 2002 \\
\hline votos usados & 13688381 & 16181423 & 18727138 \\
total de votos & 14035279 & 16258818 & 19606699 \\
\% mantida & 97,5 & 99,5 & 95,5 \\
\hline ano 2 & 1998 & 2002 & 2006 \\
\hline votos usados & 15327375 & 17391205 & 16206031 \\
Total & 16258818 & 19606699 & 21373140 \\
\% mantida & 94,3 & 88,7 & 75,8 \\
\hline \hline
\end{tabular}

Fonte: Banco de dados Eleitorais CEM/CEBRAP

Votos Válidos - par de eleições

Volatilidade Prefeito

\begin{tabular}{lccc}
\hline \hline & $1996-2000$ & $2000-2004$ & $2004-2008$ \\
\hline ano 1 & 1996 & 2000 & 2004 \\
\hline votos usados & 5215599 & 5440739 & 6155895 \\
total de votos & 5215599 & 5521182 & 6167371 \\
\% mantida & 100 & 98,5 & 99,8 \\
\hline ano 2 & 2000 & 2004 & 2008 \\
\hline votos usados & 5167914 & 5169658 & 5420873 \\
Total & 5521182 & 6167371 & 6369283 \\
\% mantida & 93,6 & 83,8 & 85,1 \\
\hline \hline
\end{tabular}

Fonte: Banco de dados Eleitorais CEM/CEBRAP 
Votos Válidos - par de eleições/educação

Volatilidade Presidente

\begin{tabular}{lccc}
\hline \hline & $1994-1998$ & $1998-2002$ & $2002-2006$ \\
\hline ano 1 & 1994 & 1998 & 2002 \\
\hline votos usados & 14793734 & 15827004 & 18869705 \\
total de votos & 15570323 & 16612001 & 19749403 \\
\% mantida & 95 & 95,3 & 95,5 \\
\hline ano 2 & 1998 & 2002 & 2006 \\
\hline votos usados & 14605516 & 17490878 & 16675815 \\
Total & 16612001 & 19749403 & 22009043 \\
\% mantida & 87,9 & 88,6 & 75,8 \\
\hline \hline
\end{tabular}

Fonte: Banco de dados Eleitorais CEM/CEBRAP

Votos Válidos - par de eleições/educação

Volatilidade Governador

\begin{tabular}{lccc}
\hline \hline & $1994-1998$ & $1998-2002$ & $2002-2006$ \\
\hline ano 1 & 1994 & 1998 & 2002 \\
\hline votos usados & 13343900 & 16169417 & 18727138 \\
total de votos & 14035279 & 16258818 & 19606699 \\
\% mantida & 95,1 & 99,5 & 95,5 \\
\hline ano 2 & 1998 & 2002 & 2006 \\
\hline votos usados & 14919435 & 17379254 & 16206031 \\
Total & 16258818 & 19606699 & 21373140 \\
\% mantida & 91,8 & 88,6 & 75,8 \\
\hline \hline
\end{tabular}

Fonte: Banco de dados Eleitorais CEM/CEBRAP

Votos Válidos - par de eleições/educação

Volatilidade Prefeito

\begin{tabular}{lccc}
\hline \hline & $1996-2000$ & $2000-2004$ & $2004-2008$ \\
\hline ano 1 & 1996 & 2000 & 2004 \\
\hline votos usados & 5203166 & 5428976 & 6155895 \\
total de votos & 5215599 & 5521182 & 6167371 \\
\% mantida & 99,8 & 98,3 & 99,8 \\
\hline ano 2 & 2000 & 2004 & 2008 \\
\hline votos usados & 5156151 & 5158454 & 5420873 \\
Total & 5521182 & 6167371 & 6369283 \\
\% mantida & 93,4 & 83,6 & 85,1 \\
\hline \hline
\end{tabular}

Fonte: Banco de dados Eleitorais CEM/CEBRAP 
Votos Válidos - eleição/educação

\begin{tabular}{lcccc}
\hline \hline Cargo & \multicolumn{4}{c}{ Presidente } \\
\hline Ano & 1994 & 1998 & 2002 & 2006 \\
\hline votos usados & 14369509 & 15828274 & 18400197 & 22009043 \\
total de votos & 15570323 & 16612001 & 19749403 & 22009043 \\
\% mantida & 92,3 & 95,3 & 93,2 & 100 \\
\hline \hline
\end{tabular}

Fonte: Banco de dados Eleitorais CEM/CEBRAP

Votos Válidos - eleição/educação

\begin{tabular}{lcccc}
\hline \hline Cargo & \multicolumn{4}{c}{ Governador } \\
\hline Ano & 1994 & 1998 & 2002 & 2006 \\
\hline votos usados & 12956764 & 16170788 & 18258410 & 21373140 \\
total de votos & 14035279 & 16258818 & 19606699 & 21373140 \\
\% mantida & 92,3 & 99,5 & 93,1 & 100 \\
\hline \hline
\end{tabular}

Fonte: Banco de dados Eleitorais CEM/CEBRAP

Votos Válidos - ano de eleição/educação

\begin{tabular}{lrrrr}
\hline \hline Cargo & \multicolumn{4}{c}{ Prefeito } \\
\hline Ano & 1996 & 2000 & 2004 & 2008 \\
\hline votos usados & 5203166 & 5428976 & 6155895 & 6369283 \\
total de votos & 5215599 & 5521182 & 6167371 & 6369283 \\
\% mantida & 99,8 & 98,3 & 99,8 & 100 \\
\hline \hline
\end{tabular}

Fonte: Banco de dados Eleitorais CEM/CEBRAP 
Resultados Eleitorais - Fonte: TSE

Eleições Presidenciais

ELEIÇÕES PRESIDENCIAIS 1989 - \% VOTOS VÁLIDOS

\begin{tabular}{lccc}
\hline \hline & BRASIL & ESTADO DE SP & CIDADE DE SP \\
\hline PRN & 30,4 & 24,4 & 17,5 \\
PDS & 8,8 & 23,5 & 24,2 \\
PSDB & 11,5 & 22,7 & 32,9 \\
PT & 17,1 & 17,4 & 15,7 \\
PL & 4,8 & 4,8 & 4 \\
OUTROS & 27,4 & 7,2 & 6,7 \\
\hline \hline
\end{tabular}

Fonte: TSE

ELEIÇÕES PRESIDENCIAIS 1994 - \% VOTOS VÁLIDOS

\begin{tabular}{lccc}
\hline \hline & BRASIL & ESTADO DE SP & CIDADE DE SP \\
\hline PSDB & 54,3 & 55,7 & 57,8 \\
PT & 27,0 & 27 & 27,2 \\
PMDB & 7,3 & 8,9 & 8,4 \\
PRONA & 4,4 & 5,7 & 4 \\
PDT & 3,2 & 0,4 & 0,4 \\
PPR & 2,7 & 1,6 & 1,7 \\
OUTROS & 1,1 & 0,7 & 0,5 \\
\hline \hline
\end{tabular}

Fonte: TSE

ELEICÕES PRESIDENCIAIS 1998 - \% VOTOS VÁLIDOS

\begin{tabular}{lccc}
\hline & BRASIL & ESTADO DE SP & CIDADE DE SP \\
\hline PSDB & 53 & 59,9 & 61,8 \\
PT & 31,7 & 28,8 & 27,7 \\
PPS & 11 & 7,4 & 7 \\
OUTROS & 4,3 & 3,9 & 3,5 \\
\hline \hline
\end{tabular}

Fonte: TSE 


\section{ELEIÇÕES PRESIDENCIAIS 2002 - \% VOTOS VÁLIDOS}

\begin{tabular}{lccc}
\hline \hline & BRASIL & ESTADO DE SP & CIDADE DE SP \\
\hline PSDB & 23,2 & 28,5 & 30,6 \\
PT & 46,4 & 46,1 & 42 \\
PPS & 12 & 10,5 & 12,7 \\
PSB & 18 & 14 & 13,8 \\
OUTROS & 0,4 & 0,9 & 0,9 \\
\hline \hline
\end{tabular}

Fonte: TSE

ELEIÇÕES PRESIDENCIAIS 2006 - \% VOTOS VÁLIDOS

\begin{tabular}{lccc}
\hline \hline & BRASIL & ESTADO DE SP & CIDADE DE SP \\
\hline PSDB & 41,6 & 54,2 & 53,9 \\
PT & 48,6 & 36,7 & 35,7 \\
PDT & 2,6 & 1,7 & 1,8 \\
PSOL & 6,8 & 7 & 8,4 \\
OUTROS & 0,4 & 0,4 & 0,2 \\
\hline \hline
\end{tabular}

Fonte: TSE

Eleições para governador de São Paulo

ELEIÇÕES GOVERNADOR 1982 - \% VOTOS VÁLIDOS

\begin{tabular}{lcc}
\hline \hline & ESTADO DE SP & CIDADE DE SP \\
\hline PMDB & 49 & 44 \\
PDS & 25,7 & 21,6 \\
PTB & 13,6 & 18,2 \\
PT & 10,8 & 14,9 \\
OUTROS & 0,9 & 1,3 \\
\hline \hline
\end{tabular}

Fonte: TSE

ELEIÇÕES GOVERNADOR 1986 - \% VOTOS VÁLIDOS

\begin{tabular}{lcc}
\hline \hline & ESTADO DE SP & CIDADE DE SP \\
\hline PMDB & 43,5 & 29,3 \\
PTB & 28,2 & 34,6 \\
PDS & 15,2 & 21,4 \\
PT & 12,1 & 12,3 \\
OUTROS & 1 & 2,4 \\
\hline \hline
\end{tabular}

Fonte: TSE 
ELEIÇÕES GOVERNADOR 1990 - \% VOTOS VÁLIDOS

\begin{tabular}{lcc}
\hline \hline & ESTADO DE SP & CIDADE DE SP \\
\hline PDS & 43,5 & 41,2 \\
PMDB & 28,2 & 19,4 \\
PSDB & 15,2 & 18 \\
PT & 12,1 & 11 \\
OUTROS & 1 & 10,4 \\
\hline \hline
\end{tabular}

Fonte: TSE

ELEIÇÕES GOVERNADOR 1994 - \% VOTOS VÁLIDOS

\begin{tabular}{lcc}
\hline \hline & ESTADO DE SP & CIDADE DE SP \\
\hline PSDB & 46,8 & 51,4 \\
PT & 14,9 & 14,9 \\
PDT & 22,2 & 22,8 \\
PMDB & 11,3 & 6,5 \\
OUTROS & 4,8 & 4,4 \\
\hline \hline
\end{tabular}

Fonte: TSE

ELEIÇÕES GOVERNADOR 1998 - \% VOTOS VÁLIDOS

\begin{tabular}{lcc}
\hline \hline & ESTADO DE SP & CIDADE DE SP \\
\hline PSDB & 22,9 & 24,9 \\
PT & 22,5 & 22,1 \\
PPB & 32,2 & 33 \\
PDT & 17,1 & 16,6 \\
PMDB & 4,2 & 2,3 \\
OUTROS & 1,1 & 1,1 \\
\hline \hline
\end{tabular}

Fonte: TSE

ELEIÇÕES GOVERNADOR 2002 - \% VOTOS VÁLIDOS

\begin{tabular}{lcc}
\hline \hline & ESTADO DE SP & CIDADE DE SP \\
\hline PSDB & 38,2 & 37,4 \\
PT & 32,4 & 30 \\
PPB & 21,3 & 25 \\
PMDB & 1,3 & 1 \\
PSB & 1,1 & 1 \\
PTB & 1 & 0,8 \\
OUTROS & 4,7 & 4,8 \\
\hline \hline
\end{tabular}

Fonte: TSE 
ELEIÇÕES GOVERNADOR 2006 - \% VOTOS VÁLIDOS

\begin{tabular}{lcc}
\hline \hline & ESTADO DE SP & CIDADE DE SP \\
\hline PSDB & 57,9 & 53 \\
PT & 31,7 & 34,2 \\
PMDB & 4,8 & 5 \\
PDT & 2 & 2,7 \\
PSB & 0,2 & 0,2 \\
OUTROS & 3,4 & 4,9 \\
\hline \hline
\end{tabular}

Fonte: TSE

Eleições para prefeito

ELEIÇÕES PREFEITURA SP

\begin{tabular}{lclllc}
\hline \hline \multicolumn{1}{c}{1985} & \multicolumn{3}{c}{1988} & \multicolumn{2}{c}{1992} \\
\hline PTB & 39,3 & PT & 36,8 & PDS & 48,8 \\
PMDB & 35,8 & PDS & 30,1 & PT & 30,7 \\
PT & 20,7 & PMDB & 17,5 & PMDB & 12,9 \\
OUTROS & 4,2 & PSDB & 6,9 & PSDB & 5,8 \\
- & - & PL & 6,6 & OUTROS & 1,8 \\
- & - & OUTROS & 2,1 & - & - \\
\hline \hline
\end{tabular}

ELEIÇÕES PREFEITURA SP

\begin{tabular}{lclclclcc}
\hline \hline \multicolumn{1}{c}{1996} & \multicolumn{1}{c}{2000} & \multicolumn{2}{c}{2004} \\
\hline PPB & 48,2 & PPB & 17,4 & PPB & 11,9 & PPB & 5,9 \\
PT & 24,5 & PT & 38,1 & PT & 35,8 & PT & 32,8 \\
PSDB & 15,5 & PSDB & 17,3 & PSDB & 43,5 & PSDB & 22,5 \\
PMDB & 2 & PSB & 9,9 & PSB & 3,9 & DEM & 33,6 \\
PDT & 7,6 & PFL & 11,4 & PDT & 1,4 & OUTROS & 5,2 \\
PTB & 0,5 & OUTROS & 5,9 & OUTROS & 3,5 & - & - \\
OUTROS & 1,7 & - & \multicolumn{2}{c}{-} & - & - & - \\
\hline
\end{tabular}

Fonte: TSE 